\title{
Geochemistry of Uranium
}

\section{in Apatite and Phosphorite}

GEOLOGIGAL SURVEY PROFESSIONAL PAPER 314-D

This report concerns work done on behalf of the U.S. Atomic Energy Commission and is published with the permission of the Commission

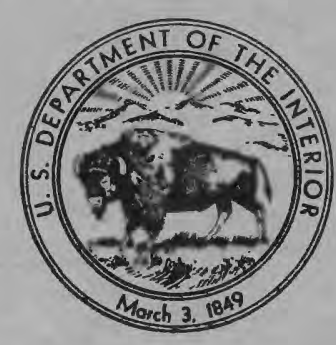





\section{Geochemistry of Uranium}

\section{in Apatite and Phosphorite}

By Z. S. ALTSCHULER, R. S. CLARKE, JR., and E. J. YOUNG

SHORTER CONTRIBUTIONS TO GENERAL GEOLOGY

GEOLOGICAL SURVEY PROFESSIONAL PAPER 314-D

This report concerns work done on behalf

of the U.S. Atomic Energy Commission

and is published with the permission

of the Commission

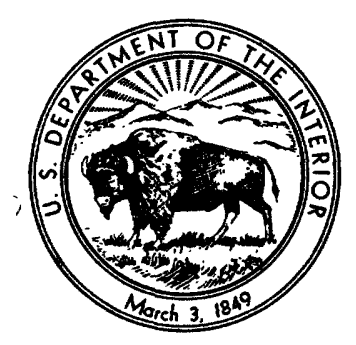

UNITED STATES GOVERNMENT PRINTING OFFICE, WASHINGTON : 1958 


\section{UNITED STATES DEPARTMENT OF THE INTERIOR \\ FRED A. SEATON, Secretary \\ GEOLOGIGAL SURVEY \\ Thomas B. Nolan, Director}

Altschuler, Zalman Samuel, 1919-

Geochemistry of uranium in apatite and phosphorite, by Z. S. Altschuler, R. S. Clarke, Jr., and E. J. Young. Washington, U. S. Govt. Print. Off., 1958.

iv, $45-90 \mathrm{p}$. illus., plates, tables. $29 \mathrm{~cm}$. (IU. S.] Geological
Survey. Professional Paper 314-D. Shorter contributions to general
geology)

Bibliography: p. 85-87.

1. Uranium ores. 2. Apatite. I. Title. (Series: U. S. Geological Survey. Prosessional Paper 314-D. Series: U. S. Geological Survey. Shorter contributions to general geology)

553.49 


\section{CONTENTS}

Abstract

Introduction.

Acknowledgments

Crystal chemite

Crystal chemistry

Composition of the sedimentary carbonate-apatites.-

Petrographic terminology ...........................

Uranium content of apatite.

Factors affecting equivalent uranium determinations .

Uranium content of representative apatites

Island phosphorites-secondary uptake of uranium and fluorine

Problems of occurrence of uranium in phosphorite

Possible modes of occurrence.....

Absence of uranium minerals...............

Relation of uranium content to composition of phosphorite.

Fluorescence and uranium content.........

Lack of preferential solution of uranium......-

Relation of uranium to $\mathrm{P}_{2} \mathrm{O}_{3}$

Marine versus ground-water origin of uranium in phosphorite.

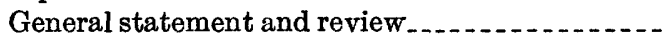

Evidence of young phosphorites and submarine nodules

Necessity of geologic interpretation

Principles governing uranium distribution in phosphorites

Uranium in phosphorite during weathering -.......

Florida Land Pebble phosphates-general geology

Illustration of leaching . . . .

Postdepositional enrichment.

Aluminum phosphate zone--lateritic weathering and supergene enrichment.........

The Cooper marl-residual enrichment...Contrasting modes of enrichment in mild versus intense weathering..............

Brown-rock phosphates of Tennessee-residual concentration

Secondary emplacement of uranium in bones..... Marine enrichment and reworking.

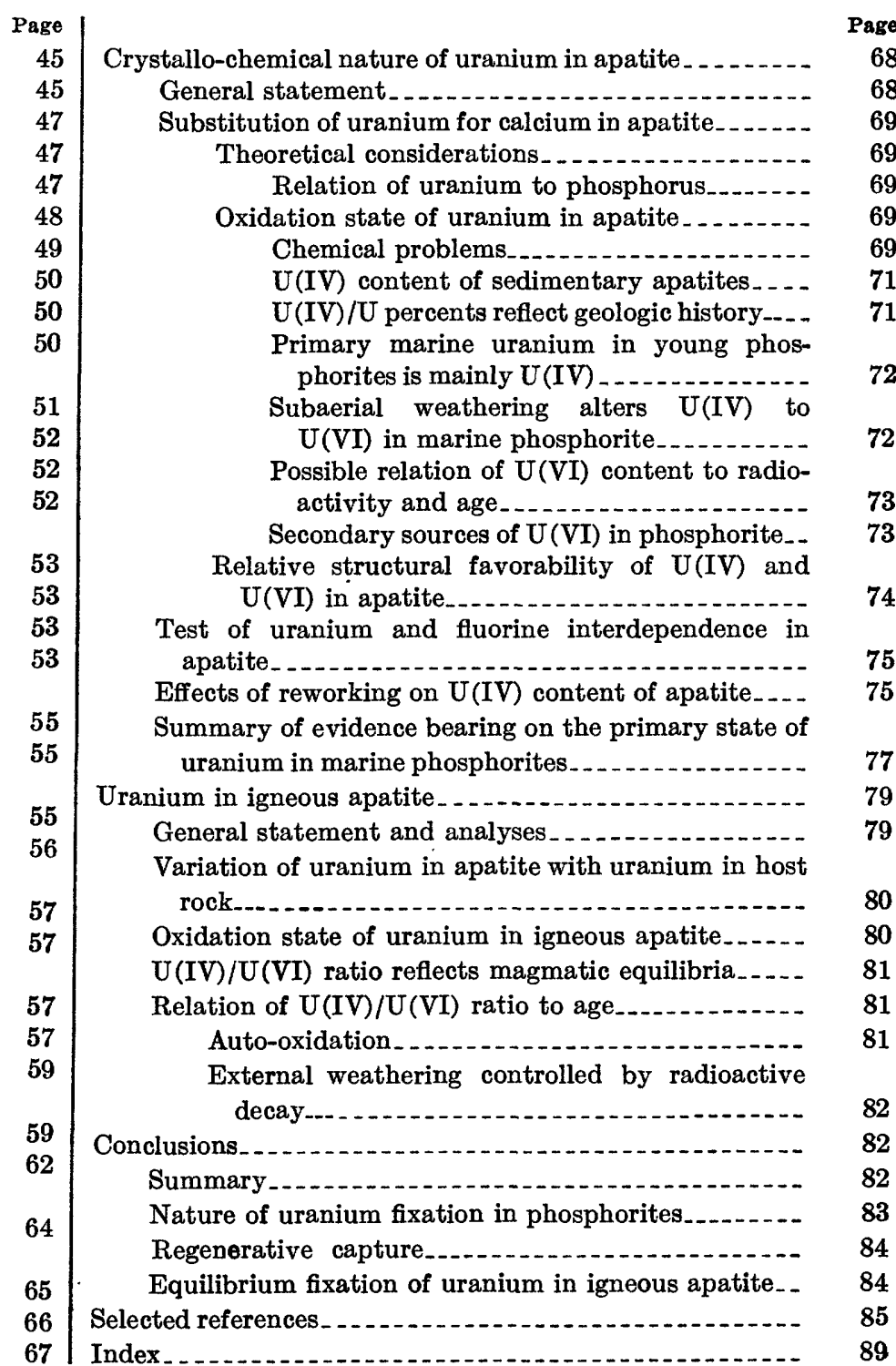

III 


\section{ILLUSTRATIONS}

[Plates follow page 60]

Plate 11. Sections and autoradiographs of sandstone, bone, and pebbles.

12. Contact of aluminum phosphate zone and overlying sand mantle, and mined-out area of Tennessee brown-rock phosphate. 13. Photomicrographs of arkosic sandstone with carbonate-fluorapatite cement from the Gas Hills area of Wyoming.

Figure 3. The structure of fluorapatite

4. Relation of uranium to $\mathrm{P}_{2} \mathrm{O}_{5}$ in Mona Island cave phosphorites

5. Relation of uranium to fluoridation in Mona Island cave phosphorites.....

6. Relation of uranium to $\mathrm{P}_{2} \mathrm{O}_{5}$ in phosphorites from Oulad-Abdoun Basin, French Morocco

7. Stratigraphic relations in the Land Pebble phosphate field, Florida

8. Sampling scheme used for study of uranium distribution in pebbles

9. Distribution of oxides through aluminum phosphate zone at Homeland, Fla

10. Uranium distribution in various textural components at Homeland mine, Fla

11. Contrasting modes of uranium enrichment and weathering in phosphorites_.

12. Sample locations for comparison of brown-rock phosphate with parent limestone in Tennessee

13. Uranium versus excess fluorine in Phosphoria formation

14. $\mathrm{U}(\mathrm{IV})$ versus excess fluorine in various phosphorites.

15. Total uranium in rock versus total uranium in apatite for rocks from Boulder Creek batholith.

\section{TABLES}

TABLE 1. Resources of some well-known uraniferous phosphorites

2. Chemical analyses of sedimentary apatite pellets from the Bone Valley formation

3. Semiquantitative spectrographic analyses of sedimentary apatite pellets

4. Thorium content of Florida pebble phosphorite

5. Uranium content of representative apatites

6. Partial analyses of cave phosphorite from Mona Island, Puerto Rico

7. Comparison of fluorescence and uranium content in composite samples of apatite nodules from the Bone Valley formation, Boyette mine, Florida

8. Size distribution and uranium contents of pelletal phosphates from Khouribga, French Morocco

9. Correlation coefficients among eU, $\mathrm{P}_{2} \mathrm{O}_{5}, \mathrm{~F}, \mathrm{CO}_{2}$ and organic matter in samples of the Phosphoria formation...--

10. "Inferred uranium contents" of Polish phosphorites...

11. Phosphate and uranium contents of bottom samples from the Gulf of Mexico

12. Relative contents of uranium and $\mathrm{P}_{2} \mathrm{O}_{5}$ in marine phosphorites.

13. Chemical analyses showing distribution of uranium within phosphate pebbles.

14. Examples of phosphate- and uranium-enriched hardpan in Cooper marl near Charleston, S. C.........

15. Comparison of phosphatized and primary Cooper marl from Lambs, South Carolina

16. Variations of enrichment with weathering in phosphatized Cooper marl, South Carolina. . . .

17. Semiquantitative spectrographic analyses of phosphatic hardpan from the Cooper marl

18. $\mathrm{P}_{2} \mathrm{O}_{5}$ and uranium content of weathered and fresh Tennessee phosphates, Akin mine, Columbia, Tenn

19. Uranium content of representative clastic apatite from the land-pebble phosphate field, Florida

20. Iron and uranium content, in weight percent, of representative apatites from the Bone Valley formation, Florida_

21. The recovery, in weight percent, of uranium(IV) from $1.5 \mathrm{M}$ phosphoric acid solutions of natural and synthetic apatite . .

22. Percentages of uranium and of U(IV) in sample B.L.-3 before and after oxidative heating ..................

23. Total and tetravalent uranium content of sedimentary apatites.

24. Experiment showing reduction of $U($ IV) by phosphoric acid solutions of hematite-rich apatite samples.

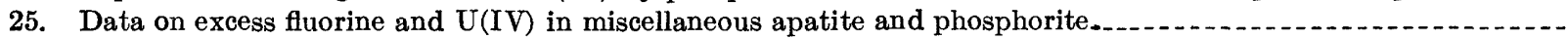

26. Relative contents of $\mathrm{U}, \mathrm{U}(\mathrm{IV})$, and $\mathrm{P}_{2} \mathrm{O}_{5}$ in phosphatic terrace gravel in the vicinity of Charleston, S. C......

27. Uranium and $U(I V)$ content of igneous apatites. 


\title{
SHORTER CONTRIBUTIONS TO GENERAL GEOLOGY
}

\section{THE GEOGHEMISTRY OF URANIUM IN APATITE AND PHOSPHORITE}

\author{
By Z. S. Altschuler, R. S. Clarke, Jr., and E. J. Young
}

ABSTRACT

Apatite contains only traces of uranium, yet as apatite is a minor constituent in most rocks and the major constituent of a few very large deposits, it accounts, paradoxically, for both dispersal and concentration of uranium in nature.

Uranium typically makes up 0.001 to 0.01 percent of primary igneous apatite and 0.005 to 0.02 percent of sedimentary marine apatite. Marine reworked apatite becomes enriched in uranium to as much as 0.1 percent. This is demonstrated by the greater uranium content of the texturally more complex phases within a single deposit.

Uranium can be secondarily leached from or introduced into apatite by ground water. These secondary changes are indicated by pronounced concentration gradients within single pebbles of apatite as well as by the redistribution of uranium among different mineral hosts in leached and altered deposits of phosphorite. The postdepositional enrichment of uranium in phosphorite may be entirely residual as in the Tennessee "brown-rock" deposits, or greatly enhanced by ground-water additions as in the South Carolina phosphates. Moreover, the pattern of enrichment reflects the conditions and intensities of weathering. Highly acid lateritic weathering has caused supergene enrichment of uranium in the aluminum phosphate zone of the Bone Valley formation. In contrast, surficial enrichment characterizes the moderately weathered Cooper Marl of South Carolina. Isolated fossil bones or phosphate pebbles may contain almost one percent of uranium as a result of ground water enrichment. Such enrichment is comparable to the postdepositional uptake of fluorine by bone or insular phosphorite, and in some places the processes are synchronous and show good mutual correlations as they are codependent on the some ground water source.

It is proposed that uranium replaces calcium in the apatite structure. This is indicated by several lines of investigation. Uranium and calcium contents are parallel in sections of leached and altered phosphorite. Ionic radii of tetravalent uranium $(0.97 \mathrm{~A})$ and divalent calcium $(0.99 \mathrm{~A})$ are virtually identical, and much of the uranium in igneous, sedimentary, and bone apatite is found to be tetravalent. Petrographic and chemical analyses and nuclear emulsion studies have shown that uranium in apatite is disseminated rather than locally concentrated. In addition, phosphate deposits are essentially devoid of uranium minerals.

The igneous apatites contain from 10 to 66 percent of their uranium as $\mathrm{U}(\mathrm{IV})$. In apatite from a suite of related igneous rocks both the total uranium and the $U($ IV $) / U(V I)$ ratio vary as the total uranium in the rock. Thus, the $U$ (IV)/U(VI) ratio in igneous apatite reflects the prevalent equilibrium conditions in the crystallizing magma.
In marine phosphorite thus far investigated the tetravalent uranium ranges from a few percent to more than 90 percent of the total uranium. Taken alone such statistics suggest a great variation in the initial $U(I V) / U$ (VI) ratio of uranium emplaced in apatite. Thus, experimental evidence that bone and apatite pellets can remove uranyl uranium from solution suggests that much of the U(VI) found in natural apatite may be of primary origin, fixed as chemically adsorbed uranyl anions. It is proposed, however, that uranium in marine apatite is emplaced primarily as U(IV), structurally fixed. This follows from the fact that the higher $U(I V) / U$ (VI) ratios are found in the younger unweathered marine apatites, and in apatites recently reworked by marine transgression. $U(I V)$ is readily oxidized to $\mathrm{U}(\mathrm{VI})$, and postdepositional weathering, facilitated by radioactive decay, has most probably lowered the initially high $U(I V) / U$ (VI) ratio in many older phosphorites.

Apatite, by effectively removing the small amounts of U(IV) produced in sea water by reduction of $\left(\mathrm{UO}_{2}\right)^{+2}$, causes more U (IV) to be produced for its own uptake. As the marine apatite is far from saturated with respect to uranium, it thus interferes with the attainment of equilibrium while flxing an unusual quantity of U(IV). The name regenerative capture is proposed for this type of concentration in which the flxation of an insig. niflcant valence species interferes with the equilibrium producing the ion and thus generates a continuing supply for further uptake and results, ultimately, in unexpectedly large build-ups of the insignificant trace element in the host mineral.

\section{INTRODUCTION}

Apatite contains only trace quantities of uranium, typically several thousandths to a few hundredths of one percent. However, as average rock has at most a few parts per million and average ocean water only one or two parts per billion, it is immediately apparent that apatite is an important concentrator of uranium in nature. The ubiquitous occurrence of apatite as an accessory mineral in igneous rocks establishes its role as an important agent, along with a few other minerals, notably zircon, monazite, and sphene, in dispersing uranium in rocks during primary differentiation. This is particularly true because apatite, unlike many other accessory minerals, is prominent in mafic as well as felsic rocks. Thus, whereas the uranium content may be low in the gabbros, the contribution of apatite to the total budget of uranium in the early differentiates may 
be correspondingly higher. As apatite is also rather common in shales and limestones in the form of phosphatic nodules, concretions, and fossil replacements, it is evident that apatite plays a major role in the geochemical cycle of uranium.

Beside contributing to the dissemination of uranium, apatite paradoxically is also one of very few minerals causing immense localizations of this element. It does so by virtue of its occurrence in vast accumulations of marine sedimentary phosphate composed essentially of the mineral carbonate-fluorapatite (Altschuler and others, 1953). Table I illustrates the magnitude and economic potential of these deposits. Thus, as we annually produce more than ten million tons of phosphate fertilizer in the United States and as an appreciable part of this is processed chemically, an opportunity is afforded to mobilize and extract many hundreds of tons of uranium each year. Indeed, uranium as a byproduct of triple superphosphate production is now recovered in several plants in the United States (Barr, 1955).

TABLE 1.-Resources of some well-known uraniferous phosphorites

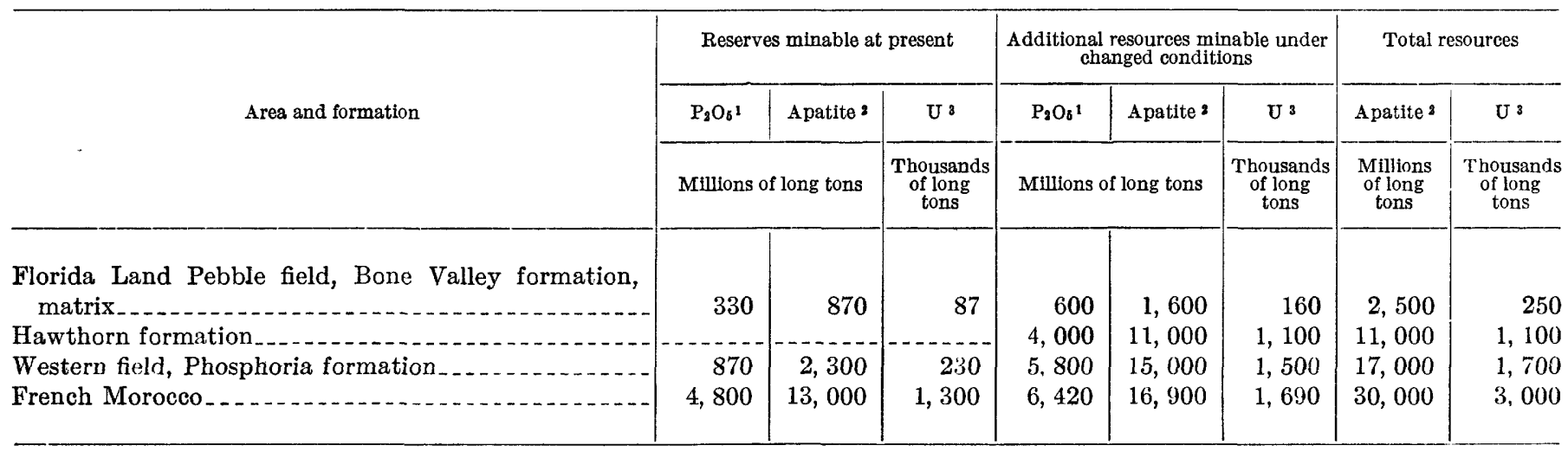

1 Data on $\mathrm{P}_{2} \mathrm{O}_{6}$ from Le Cornec (1951) for Moroccan deposits and McKelvey and others (1953), for domestic deposits.

2 A patite data have been computed on the basis of an assumed average $\mathrm{P}_{2} \mathrm{O}_{3}$ content of 38 percent in the carbonate-fluorapatite comprising these deposits. Generally such compilations show BPL (bone phospnate of lime or tri-calcium phosphate) and as the $\mathrm{BPL}$ is in turn based on theoretical fluorapatite of 42 percent $\mathrm{P}_{2} \mathrm{O}_{5}$, it is

The principal aims of this report are three: to survey the uranium content of a variety of apatite materials and deposits; to portray the geologic and chemical controls of uranium distribution in phosphorites of various origins; to attempt an explanation of the occurrence of uranium in apatite.

We shall be concerned largely with the migration and fixation of an element that seldom exceeds 0.01 percent in the rocks studied. However, it is best to begin with a discussion of some of the restrictions which this low concentration imposes on the approach taken. Owing to its unusual properties of radioactivity and conferred fluorescence, uranium, unlike most trace elements, may often be followed in the field virtually as one follows a visible, major, mineral component. The same properties have allowed the development of analytical methods (Grimaldi and others, 1952) that permit accurate detection of uranium at extremely low concentrations. Unlike an investigation of a major element, however, a study of a trace constituent, in an impure material like phosphorite, is handicapped by lack of information on bulk composition. Whereas it is true both fictitious and misleading. This table gives $\mathrm{P}_{2} \mathrm{O}_{5}$ and apatite that is minable, rather than tons of minable rock. The latter term does not. correctly refiect absolute composition due to its dependence on a complex of external factors such as grade (amount of diluent), thickness, and overburden depth.

8 Based on the conservative estimate of 0.01 percent $U$ in the pure apatite.

that one may obtain the general composition of the mineral host with moderate accuracy-and even here the carbonate-apatite problem is a vexing intrusionthe tiny quantities of uranium dealt with suggest that most of the trace element assemblage be quantitatively determined. Otherwise, the immediate environment of each uranium sample is but poorly known. Obviously, it is impossible to overcome this difficulty in most cases because of the prohibitive time and money requirements, and the fact that adequate analytical methods are not available for many minor and trace elements. Instead, reliance must be placed on a reconstruction of conditions from field and petrographic facts and on selection of several elements for specific analysis. Thus, in studying the phosphorites, uranium contents are evaluated mainly in relation to $\mathrm{P}_{2} \mathrm{O}_{5}$ content. Where important, fluorine, iron, calcium, aluminum or organic matter may also be studied. However, implicit in some of the work that follows is the assumption that uranium in phosphate nodules is associated mainly with the apatite composing the nodules, and that trace to minor amounts of included carbonates, clays, iron-oxides, 
quartz, pyrite, and organic matter contain only insignificant amounts of uranium.

Three lines of evidence validate this assumption:

1. Many phosphorite samples have been analyzed by two different methods, one, using weak acids, in which apatite dissolves readily, and clays, pyrite, iron-oxides or quartz would remain insoluble or dissolve only on prolonged treatment; the other, using a mixture of hydrofluoric and nitric acids in which all of the rock dissolves. In all samples the uranium determined was essentially the same by both methods.

2. Chemical analyses of the minerals associated with apatite in the Florida and Moroccan deposits showed their uranium content to be insignificant relative to that of apatite.

3. Nuclear emulsion studies reveal that most of the radioactivity in phosphate nodules comes from apatite.

\section{ACKNOWLEDGMENTS}

The field and laboratory studies which this paper summarizes have been part of the U. S. Geological Survey's program of investigation of radioactive raw materials for the Division of Raw Materials of the U. S. Atomic Energy Commission. We have benefited greatly from the unpublished studies of many of our colleagues in the Geological Survey engaged in complementary and parallel studies of phosphorite. We are especially indebted to V. E. McKelvey and J. B. Cathcart, whose regional studies have contributed much important information on the geologic occurrence of phosphorite and uranium; to W. W. Rubey, whose earlier unpublished investigations and recommendations were largely instrumental in implementing the Survey's program of phosphorite investigations; and to the late John C. Rabbitt, whose reviews and suggestions in the senior author's unpublished studies are reflected in much that follows. We have also benefited greatly from the advice and interest of R. M. Garrels and F. S. Grimaldi in many helpful discussions of the chemical problems, from the stimulating discussions of regional weathering patterns with C. B. Hunt, and from the thoughtful and constructive reviews of $\mathrm{E}$. S. Larsen, 3d, and R. P. Sheldon. The following Geological Survey colleagues furnished analyses: A. B. Caemmerer, Frank Cuttitta, G. J. Daniels, G. Edgington, Katherine Valentine Hazel, C. L. Johnson, Harry Levine, A. R. Schrenk, and Helen W. Worthing.

We are deeply grateful to the mining and administration staffs of the many companies engaged in phosphate mining in central Florida for their wholehearted cooperation in allowing access to operating quarries during fieldwork from 1949 to 1954.

\section{MINERALOGY OF APATITE}

\section{CRYSTAL CHEMISTRY}

It is important in considering the nature of uranium occurrence in apatite and phosphorite deposits to understand the possible variations in apatite composition. Basically, apatite is a hexagonal network structure composed of $\mathrm{PO}_{4}$ tetrahedra, a simple anion (usually fluorine) and a divalent cation, calcium. Beevers and McIntyre (1946) liken the structure to a honeycomb (fig. 3) with the vertices made up of vertical $\mathrm{Ca}-\mathrm{O}$ columns in which the oxygens are supplied by $\mathrm{PO}_{4}$ tetrahedra intervening between columns and linking adjoining columns together in a continuous structure. The fluorine or hydroxyl ions occur vertically above each other within the channels of the honeycomb, where they are coordinated to additional calciums (three about each fluorine) that occur in "caves" within the irregular walls of the network (Beevers and McIntire, 1946).

Apatite is host to many substitutions by cations, anions, and anionic radicals that resemble its normal constituents in size and charge (McConnell, 1938). As a result it may depart significantly from the composition of simple igneous fluorapatite, depending on its environment of genesis. The fluorine position may be occupied wholly or in part by hydroxyl. (Chlorine may also substitute for fluorine; however, as their size difference is appreciable, a structural rearrangement occurs in chlorapatite and it has only limited miscibility with fluorapatite.) In fossil bone, hydroxyl is eventually replaced by fluorine through ion exchange. Minor to major amounts of $\mathrm{Sr}, \mathrm{Mn}, \mathrm{Mg}$, and $\mathrm{Pb}$ are known to replace calcium in apatite, and $\mathrm{VO}_{4}$ and $\mathrm{AsO}_{4}$ occur as traces substituting for $\mathrm{PO}_{4}$ in apatite and form analogues of normal apatite in the pyromorphite series (Palache and others, 1951).

Additional variety is effected by the opportunity for coupled diadochy in which cationic or anionic replacements causing loss or gain in valence are balanced by replacements of opposite kind. Thus, in apatites containing rare earths the imbalance created by the substitution of tervalent cerium for calcium is quantitatively compensated by substitution of tetravalent silicate for phosphate or by the monovalent sodium for calcium (Borneman-Starinkevitch, 1938; Volodchenkova and Melentiev, 1943). An analogous situation exists in many other phosphate mineral groups. For example, monazite, the cerium phosphate, contains thorium and silicate in roughly equivalent amounts. 


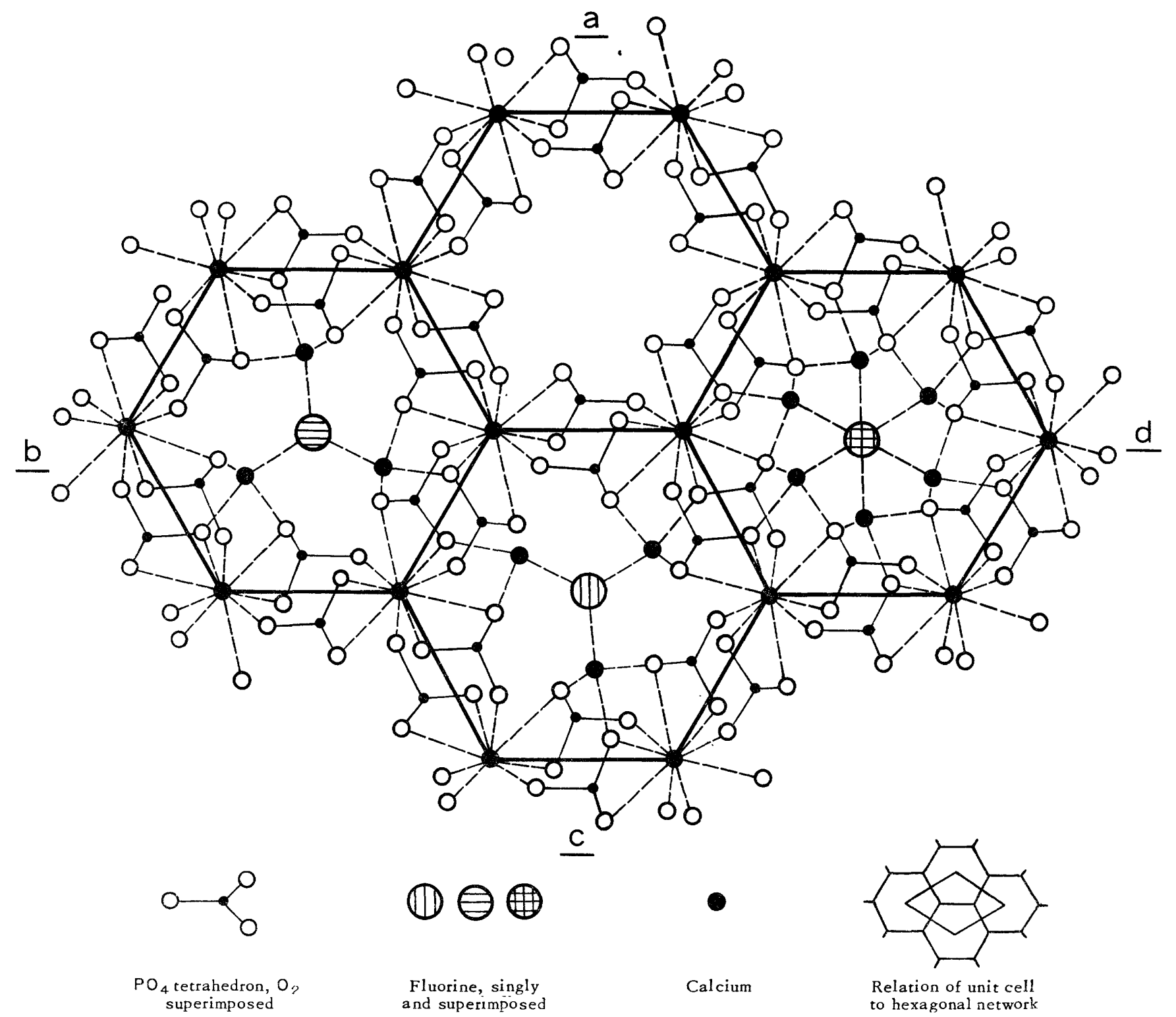

Figurn 3.-The structure of fluorapatite showing progressive stages of completion as viewed looking down the $\mathrm{C}$ axis. (Based on drawings of Beevers and McIntyre, 1946.) a, Incomplete structure showing hexagonal framework and unoccupied channels; b, addition of 3 channel calciums and a fluorine occupying same plane; c, position of second planar group of 3 channel calciums and 1 fluorine, at a different vertical height in the structure; $d$, complete structure.

\section{COMPOSITION OF THE SEDIMENTARY CARBONATE-APATITES}

The fine-grained microcrystalline carbonate-apatites of the insular and marine phosphorites are best understood in terms of such coupled substitutions. This apatite is generally characterized relative to fluorapatite by a deficit in $\mathrm{P}_{2} \mathrm{O}_{5}$ content of 3 to 6 percent, an excess of $\mathrm{F}, \mathrm{OH}$ (or both) of 0.5 to 1.0 percent, and by the presence of 2 to 3 percent of carbonate. The exact mode of occurrence of carbonate in apatite is a controversial question. Hendricks and Hill (1950) have proposed that the carbonate is adsorbed on the surfaces of discontinuities within the apatite crystals. It is significant, however, that carbonate fluorapatite is demonstrably smaller in unit-cell dimensions than fluorapatite (Altschuler and others, 1953). It is felt therefore that the structural difference revealed by the characteristically smaller cell must reflect the major and equally characteristic chemical deviations, and that carbonatefluorapatite is a structurally distinct species as proposed by Gruner and McConnell (1937). Lacking a precise determination of the position of carbonate in the structure we shall adopt provisionally the structural formula which best rationalizes the chemical composition, as 
follows: $\mathrm{Ca}_{10}\left(\mathrm{PO}_{4}, \mathrm{CO}_{3}\right)_{6} \mathrm{~F}_{2-3}$. Thus excess fluorine (or hydroxyl) serves to balance the charge difference created by the substition of $\left(\mathrm{CO}_{3}\right)^{-2}$ for $\left(\mathrm{PO}_{4}\right)^{-3}$.

The chemical and spectrographic analyses in tables 2 and 3 illustrate the chemical nature of the sedimentary carbonate-fluorapatites. Theoretical fluorapatite has the following composition:

$$
\begin{aligned}
\mathrm{CaO} & =55.5 \text { (includes } \mathrm{F} \text { for } \mathrm{O}=1.6 \text { ) } \\
\mathrm{P}_{2} \mathrm{O}_{5} & =42.3 \\
\mathrm{~F} & =3.8
\end{aligned}
$$

The analyses portray the deficiency of $\mathrm{P}_{2} \mathrm{O}_{5}$ relative to $\mathrm{CaO}$ (augmented by $\mathrm{Na}, \mathrm{Mg}, \mathrm{Sr}$ and other divalent metals shown in table 3 ), and the excess of $\mathrm{F}$ plus $(\mathrm{OH})$. It should be noted in table 2 that the carbonate is substantially all nonleached and therefore assignable to apatite.

Sedimentary carbonate-hydroxylapatite occurs as nodules or massive deposits in caves or islands and is indicative of continental origin. It usually originates as a replacement of limestone by guano solutions. In the presence of fluorine, carbonate-fluorapatite is the stable form and it precipitates as such in marine sediments (Kazakov, 1937). Furthermore, fluorapatites

TABLE 2.-Chemical analyses of sedimentary apatite pellets from

\begin{tabular}{|c|c|c|c|c|c|c|}
\hline & \multicolumn{3}{|c|}{$\begin{array}{l}\text { B. L.-3, Bonny Lake } \\
\text { mine, Ridgewood, Fla. }\end{array}$} & \multicolumn{3}{|c|}{$\begin{array}{l}\text { Wa.-10, Watson mine, } \\
\text { Fort Meade, Fla. }\end{array}$} \\
\hline & 1 & 2 & 3 & 1 & 2 & 3 \\
\hline Acid insoluble & & 6.6 & & 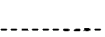 & 2.4 & \\
\hline $\mathrm{CaO}$ & 49.5 & $-\ldots$ & 52.9 & 51.5 & $\ldots$ & 52.7 \\
\hline $\mathrm{P}_{2} \mathrm{O}_{5}$ & 34.9 & $-\ldots$ & 37.3 & 36.6 & $\ldots$ & 37.5 \\
\hline $\mathrm{CO}_{2}$ & 2.1 & 2.0 & 2.2 & 1.9 & 1.7 & 1.9 \\
\hline $\mathrm{SiO}_{2}$ (total) & 6.7 &.- & -.... & 2.9 & $\ldots$ & $-\ldots$ \\
\hline $\mathrm{SiO}_{2}$ (soluble) & -.......... & .8 & .9 & - nas & 1.1 & 1.1 \\
\hline $\mathrm{SO}_{3}$ & .3 & $\ldots$ & .3 & .1 & $\ldots$ & .1 \\
\hline $\mathrm{Al}_{2} \mathrm{O}_{3} \ldots$ & 1.4 & $\ldots$ & 1.5 & 1.1 & $\ldots$ & 1.1 \\
\hline $\mathrm{Fe}_{2} \mathrm{O}_{3}$ & .4 & $-\ldots$ & .4 & .9 & $-\ldots$ & .9 \\
\hline $\mathrm{Na}_{2} \mathrm{O}$ & .1 & $-\ldots$ & .1 & .2 & $\ldots$ & .2 \\
\hline $\mathrm{K}_{2} \mathrm{O}$ & .1 & $\ldots$ & .1 & .2 & $-\ldots$ & .2 \\
\hline $\mathrm{H}_{2} \mathrm{O}(+)$ & 1.6 & $-\ldots$ & 1.7 & 1.8 & $-\ldots$ & 1.8 \\
\hline $\mathrm{H}_{2} \mathrm{O}(-)$ & 1.0 & .6 & 1.1 & .7 & .5 & .7 \\
\hline U & .016 & & .017 & .0075 & $\ldots$ & .0077 \\
\hline F & 3.8 & $--\ldots$ & 4. 1 & 3.8 & $-\ldots$ & 3.9 \\
\hline Total-_ & 101.9 & $-\ldots$ & 102.6 & 101.7 & $-\ldots$ & 102.1 \\
\hline $\mathrm{F}=\mathrm{O}$ & 1.6 & $-\ldots$ & 1.7 & 1.6 & $\ldots$ & 1.6 \\
\hline Corrected total........... & 100.3 & -.... & 100.9 & 100.1 & ..... & 100.5 \\
\hline Nonleachable $\mathrm{CO}_{2} \ldots$ & $\ldots$ & 1.8 & $-\ldots .$. & - & 1.6 & - n \\
\hline
\end{tabular}
the Bone Valley formation

[Analyst, R. S. Clarke, Jr.]

1. Analysis by complete decomposition of sample by solution in $\mathrm{HNO}_{3}$ and fusion of insoluble residue with $\mathrm{Na}_{2} \mathrm{CO}_{3}$

2. Partial analyses of same material. Acid insoluble determined after boiling sample for 20 minutes with $1+3 \mathrm{HCl}$. Nonleachable carbonate determined after treatment in 0.5 M tri-ammonium citrate (Silverman, Fuyat, and Weiser, 1952).

3. Corrected analysis, free of insoluble residue. Microscopic examination and the two sets of $\mathrm{SiO}_{2}$ figures establish that acid insoluble is essentially quartz.

\begin{tabular}{|c|c|c|c|c|c|}
\hline $\begin{array}{l}\text { Weight } \\
\text { percent }\end{array}$ & B. I. -31 & Wa. $-10^{2}$ & $\operatorname{Va} .7^{3}$ & K.-1 & K.-154 \\
\hline Over 10.0 & Ca. P & $\mathrm{Ca}, \mathrm{P}$ & $\mathrm{Ca}, \mathrm{P}$ & $\mathrm{Ca}, \mathrm{P}$ & $\mathrm{Ca}, \mathrm{P}$. \\
\hline $10.0-5.0 \ldots$ & $\mathrm{Si}_{\ldots} \ldots$ & - & 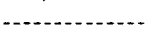 & - & \\
\hline $5.0-1.0$ & $\mathrm{Al} \ldots$ & (n) & $\mathrm{Si}$ & & Si. \\
\hline $1.0-0.5 \ldots$ & - & $\mathrm{Si}, \mathrm{Al}, \mathrm{Fe}$ & & & $\mathrm{Na} \quad \mathrm{Mg} \quad \mathrm{Al}$ \\
\hline $0.5-0.1$ & $\begin{array}{l}\mathrm{Mg}, \mathrm{Fe} \\
\mathrm{Na} .\end{array}$ & $\mathrm{Na}, \mathrm{Mg}$ & $\left\{\begin{array}{l}\text { Al, Fe, Mg, } \\
\mathrm{Na} .\end{array}\right.$ & $\begin{array}{l}\text { Na, Si, Al, } \\
\text { Mg. }\end{array}$ & $\mathrm{Na}, \mathrm{Mg}, \mathrm{Al}$ \\
\hline $0.1-0.05 \ldots$ & $\mathrm{Sr}, \mathrm{Ti}$ & $\mathrm{Ti}, \mathrm{V}, \mathrm{Sr}$ & $\mathrm{Sr}, \mathrm{Y}, \mathrm{I}$ & $\mathrm{Cr}, \mathrm{V}, \mathrm{Y}$, & $\mathrm{Fe}, \mathrm{Sr}, \mathrm{C}$ \\
\hline $0.05-0.01$ & $\begin{array}{l}\mathrm{Pb}, \mathrm{Mn} \\
\mathrm{Cr} .\end{array}$ & $\begin{array}{l}\text { Mn, B, Y, } \\
\text { Cr. }\end{array}$ & Ti, Zr, B. & $\mathrm{Fe}, \mathrm{Sr}$ & V.Y.Ni. \\
\hline $0.01-0.005$ & & $\mathrm{Ba}, \mathrm{La}, \mathrm{Ni}$ & $\begin{array}{c}\mathrm{Mn}, \mathrm{V}, \mathrm{Ba} \\
\mathrm{Ni}, \mathrm{Yb} .\end{array}$ & $\begin{array}{l}\mathrm{Ni}, \mathrm{La}, \mathrm{Ba}, \\
\mathrm{Ti}, \mathrm{Zr} .\end{array}$ & $\begin{array}{l}\mathrm{Mn}, \mathrm{Ti}, \mathrm{Ba}, \\
\mathrm{La}, \mathrm{Cu} .\end{array}$ \\
\hline $0.005-0.001 \ldots$ & $\mathrm{Cu}, \mathrm{V}, \mathrm{Y}_{--}$ & $\mathrm{Zr}, \mathrm{Yb}, \mathrm{Cu}$ & $\begin{array}{l}\mathrm{Cr}, \mathrm{Pb}, \mathrm{Cu} \text {, } \\
\text { Sc. }\end{array}$ & $\begin{array}{c}\mathrm{Cu}, \mathrm{Mn}, \mathrm{Yb}, \\
\mathrm{Yb}, \mathrm{Ag} .\end{array}$ & $\begin{array}{l}\mathrm{Zr}, \mathrm{Mo}, \mathrm{Yb} . \\
\mathrm{Ag} .\end{array}$ \\
\hline $0.001-0.0005$ & & $\mathrm{Ag} \mathrm{B}$ & $\mathrm{Ag}$ & & \\
\hline $0.0005-0.0001$ & $Y_{b}$ & & & & \\
\hline
\end{tabular}

$\mathrm{T}_{\mathrm{ABLE}}$ 3.-Semiquantitative spectrographic analyses of sedimentary apatite pellets

1 Bone Villey formation, Bonny Lake mine, Ridgewood, Fla.; analyst, Katherine V. Hazel.

Bone Valley formation, Watson mine, Fort Meade, Fla.; analyst, Katherine $\mathbf{v}$. Hazel.

Bone Valley formation, Varn mine, Fort Meade, Fla.; analyst, Katherine V. Hazel.

4 Daily production samples, Khouribga, French Morccco; analyst, Helen W. Worthing.

are less soluble than hydroxylapatites, and carbonatefluorapatite can replace previously formed hydroxyl varieties in bone and island phosphorites. This last fact was demonstrated in the classic investigations of Carnot (1893) and is the basis of the current interest in water fluoridation for the prevention of caries, as well as being partly responsible for the dramatic revelation of the Piltdown forgery (Oakley, 1955b; Weiner and others, 1953).

\section{PETROGRAPHIC TERMINOLOGY}

Many of the petrographic terms common in phosphorite literature are ambiguous. The terms used in the present report are defined here. Most marine phosphate deposits contain oviform particles ranging in size from granules to fine sand $(4.0$ to $0.06 \mathrm{~mm})$ and composed almost entirely of carbonate-fluorapatite. These may display oolitic structures; many of them are replaced fossils; many show no textures or structures. Reflecting the variety of possible origins of the deposits, the names oolites, nodules, pellets, and granules have been frequently employed for all of the ovules. The term "oolite" properly denotes only small round particles evincing accretionary textures; the term "granule" is primarily a size term; and the term "nodule" is too nonspecific to be useful here as it usually applies to round irregular masses of any size and may embrace rock as well as monomineralic particles. In keeping with similar usage by V. E. McKelvey and his colleagues (oral communication, 1950) the term "pellet"

$468547-58-2$ 
is used as a general term for oviform sedimentary apatite particles.

The term "phosphorite" has gained increasing acceptance as a rock name synonymous with the cumbersome term "phosphate rock." It is used here to denote rock or specimen containing substantial sedimentary apatite. Thus, one may speak of a "phosphorite sample," a "phosphorite deposit," or a "phosphorite pebble." The last would denote a round pebble-size rock fragment, rich in apatite but containing other minerals such as quartz, clay, and calcite. In contrast the term "apatite pebble" denotes a pebble-size, round or rounded, fragment of virtually pure apatite.

\section{URANIUM CONTENT OF APATITE}

\section{FACTORS AFFECTING EQUIVALENT URANIUM DETERMINATIONS}

The occurrence of uranium in phosphate nodules, bones, and other apatite materials was first demonstrated by Strutt in a remarkable set of analyses based on radioactivity determinations (Strutt, 1906, 1908). Strutt pointed out that the determinations were not affected by thorium which is virtually absent in fossil bone or sedimentary apatite, as is borne out by the analyses of phosphorite pebbles given in table 4 .

TABLE 4.-Thorium contents of Florida pebble phosphorite

[Analyses from U. S. Geological Survey laboratory]

\begin{tabular}{|c|c|c|}
\hline Locality & Percent Th & Percent U \\
\hline South Pierce mine, Brewster............. & $<0.0005$ & 1 n. d. \\
\hline Carmichael mine, Plant City & .001 & in. d. \\
\hline Bonny Lake mine, Mulberry & .0007 & 0.017 \\
\hline
\end{tabular}

1 Although uranium was not determined on these samples, similar materials from the same localities contain $0.01-0.02$ percent of uranium.

Available analyses of igneous apatite show three or four times more thorium than uranium, and if rich in rare earths, igneous apatite may contain as much as 0.38 percent of $\mathrm{Th}$, as reported in apatite from Mineville, N. Y. (McKeown and Klemic, 1956).

Despite the lack of thorium in phosphorite, it is nevertheless preferable to base a discussion of uranium on chemical rather than radiometric determinations. This is particularly true in view of the ease with which apatite can be postdepositionally leached or enriched in uranium and thus be out of radioactive equilibrium regardless of its age. In addition, due to a great variation in the size of the inherent crystallites of the sedimentary apatites (Jacob and Hill, 1953), it is difficult to maintain the standardization necessary to establish comparable equivalent-uranium results among a variety to materials, regardless of the fact that they may all be ground to the same apparent size prior to radiometric assay. It is perhaps for these reasons that the equivalent-uranium figures presented in the excellent summary of Hébert (1947) are somewhat high. The discrepancies in Hébert's and in Guntz's data (1952) have been pointed out by Davidson and Atkin (1953) in their very thorough review and discussion.

\section{URANIUM CONTENT OF REPRESENTATIVE APATITES}

Table 5 presents typical and commonly encountered values obtained in a variety of apatite materials studied

TABLE 5.-Uranium content of representative apatites

[Asterisk indicates values considered by the authors to be typical for such material. Analyses from U. S. Geological Survey Laboratory]

A. Fluorapatite, $\mathrm{Ca}_{10}\left(\mathrm{PO}_{4}\right)_{6} \mathrm{~F}_{2}$, from crystalline rocks

1. Alkali syenite, Renfrew, Ontario, Canada.-.-

Uranium

2. Gabbro, Henderson, N. Carolina _._. 0006

3. Shonkinite, Mountain Pass, California _..... . 0049

4. Magnetite deposit, Durango, Mexico _._._. . . 0009

5. Magnetite deposit, Mineville, New York.... . 079

6. Syenite, Kola Peninsula, U.S.S.R _..._. _. . - <. 001

7. Tonalite, southern California batholith...... $\quad .012$

8. Granodiorite gneiss, Boulder Creek batho-

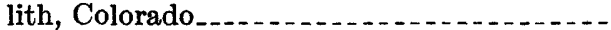

9. Quartz monzonite, Boulder Creek batholith, Colorado ..........

10. Hornblende biotite granite, Boulder Creek batholith, Colorado........

11. Mica granite, Boulder Creek batholith, Colorado... . . . . . . . . . . . . . . . . . . .

12. Quartz diorite gneiss, Boulder Creek batholith, Colorado

B. Carbonate-fluorapatite $(F=>1$ percent $), C a_{10}\left(P O_{4}\right.$, $\left.\mathrm{CO}_{3}\right)_{6}(\mathrm{~F}, \mathrm{OH})_{2-3}$ from marine sedimentary phosphorite

1a. Pellets, Hawthorn formation, Florida ........

b. Do. .

c. Do

2a. Pellets, Bone Valley formation, Florida.....

b. Do....

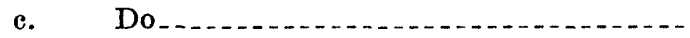

3a. Pebbles, Bone Valley formation, Florida . . .

b. Do.......

c. Do Do.

4a. Pellets and oolites, Phosphoria formation, Idaho

b. Do . .

5a. Pellets and replaced fossils, Khouribga, French Morocco . . . . . . . . . .

b. Do $\quad$ Doch

c. Do ....................

6. Nodules dredged from the sea floor off southern California

Sample No.

$69 \ldots 089$

(Samples, those analyzed for Dietz, Emery, and Shepard, 1942). 
TABue 5.-Continued

C. Fossil Bone, carbonate-fluor-hydroxylapatite $(F=<$ 1 percent) $\mathrm{Ca}_{10}\left(\mathrm{PO}_{4}, \mathrm{CO}_{3}\right)_{6}\left(\mathrm{OH}, \mathrm{F}^{\prime}\right)_{2-3}$

1. $\mathrm{RW}-4468$, mammalian (sp. unknown), Mayport, Florida

2. W-3841, mammalian (sp. unknown), Miles

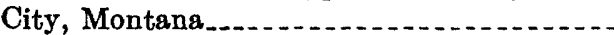

3. Titanothere bone, Hell Creek formation, Camp Cook, South Dakota

4. Shark tooth, Bone Valley formation, Florida...

5. Manatee rib, Bone Valley formation, Florida..

6. Conodont fragments, Khouribga, French Morocco . . . . . . . . . . . . . . . . . . .

D. Guano-derived phosphorites, carbonate-hydroxylapatite $\mathrm{Ca}_{10}\left(\mathrm{PO}_{4}, \mathrm{CO}_{3}\right)_{6}(\mathrm{OH})_{2-8}$

1. Angaur Island, Pacific Ocean . .............. 0.074 .83

.015

.009

.006

.079

2. Mona Island, Puerto Rico .................. 001

3. Cuthbert Lake Rookery, Tampa Bay, Florida $-<.001$

by the U.S. Geological Survey. In all cases the analyses are chemical ${ }^{1}$ and represent the contents of individual mineral specimens or pure mineral concentrates rather than total rock and hence are of additional value in the geologic literature and do not duplicate the excellent summaries of uranium in certain phosphorite deposits (Rusakov, 1953; Hébert, 1947; Davidson and Atkin, 1953; McKelvey and Nelson, 1950; McKelvey and others, 1955; Thompson, 1953; Cathcart, 1956).

It is apparent from the above data that uranium content in apatite materials as a group varies from barely detectable traces to the concentration of a minor constituent, approaching 1 percent. Nevertheless, within major occurrences of the same nature, as exemplified by the igneous rocks of the Boulder Creek batholith, or all of the immense marine phosphates, the level of concentration is of the same order of magnitude, $0.00 \mathrm{X}$ to 0.03 percent. This range in uranium content may be taken to embrace the great bulk of apatite in the lithosphere and departures from it may be safely considered unusual and examples of special history.

\section{ISLAND PHOSPORITES-SECONDARY UPTAKE OF URANIUM AND FLUORINE}

The unusually low uranium contents of island phosphorite, as illustrated by the Angaur and Mona Island analyses (table 5) are attributable to the lack of uranium in the parent limestones from which they originate by subaerial replacement. Only rarely do

1 The uranium analyses reported in this paper that have been performed in the U. S. Geologlcal Survey laboratories have been done by fluorimetric methods. Grimaldi and others (1954) discuss the accuracy of these methods pointing out that they may be as good as \pm 4 percent of the uranium content. They state that under routine conditions, "The error generally is greater and may range from \pm 8 to 15 percent of the uranium content. When errors occur, the results are generally low." Most of the analyses in this paper have been done by a finorimetric-extraction procedure. For this reason, as well as because of the nonroutine nature of the determinations, it is safe to assume them to be accurate in the range of \pm 5 percent of the uranium present. island phosphorites contain more than 0.002 percent uranium and where they exceed this value the uranium in all likelihood has been acquired postdepositionally from percolating ground water or from sea water with which such deposits are sprayed or washed by wind and wave. It is of interest in this regard to compare the fluorine and uranium contents of such materials, as fluorine, not being a primary constituent of subaerially formed phosphorites, is a certain indicator of postdepositional replacement.

Table 6 and figure 4 show that the percentage of uranium bears least relation to the $\mathrm{P}_{2} \mathrm{O}_{5}$ content or, inferentially, to the amount of apatite present in the rock. Thus specimens $3,7 \mathrm{a}$, and 8 are all virtually pure apatite rock yet their uranium contents differ by several hundred percent. In contrast, uranium generally increases as fluorine, or as the ratio of fluorine to phosphorus does. The lack of a constant ratio between the increases is easily explained by the fact that two independent structural emplacements are involved, $F$ for

TABLE 6.-Partial analyses of cave phosphorite from Mona Island, Puerto Rico

\begin{tabular}{|c|c|c|c|c|c|}
\hline Sample & $\left|\begin{array}{c}\mathrm{P}_{2} \mathrm{O}_{5} \\
\text { (percent) }\end{array}\right|$ & $\begin{array}{c}F^{2} \\
\text { (percent) }\end{array}$ & $\underset{\text { (percent) }}{\mathrm{U}^{3}}$ & $\frac{F}{\mathrm{P}_{2} \mathrm{O}_{3}} \times 100$ & $\frac{U}{\mathrm{P}_{2} \mathrm{O}_{3}} \times 10,000$ \\
\hline Mona 6. - & 26. 3 & 0.07 & 0.0003 & 0.27 & 0.11 \\
\hline $7 b_{-}$ & 15.8 & .06 & .0003 & .38 & .19 \\
\hline $3 \ldots$ & 41.4 & .05 & .0005 & .12 & .12 \\
\hline $4 \ldots \ldots$ & 32.4 & 24 & .0011 & .74 & .34 \\
\hline $8 \ldots$ & 38. 6 & 1. 08 & .0028 & 2. 80 & .73 \\
\hline $7 a_{\ldots} \ldots$ & 37.1 & .65 & .0014 & 1. 75 & .38 \\
\hline
\end{tabular}

1 Analyst, A. B. Caemmerer.

2 Analyst, G. Edgington.

Analyst, C. L. Johnson.

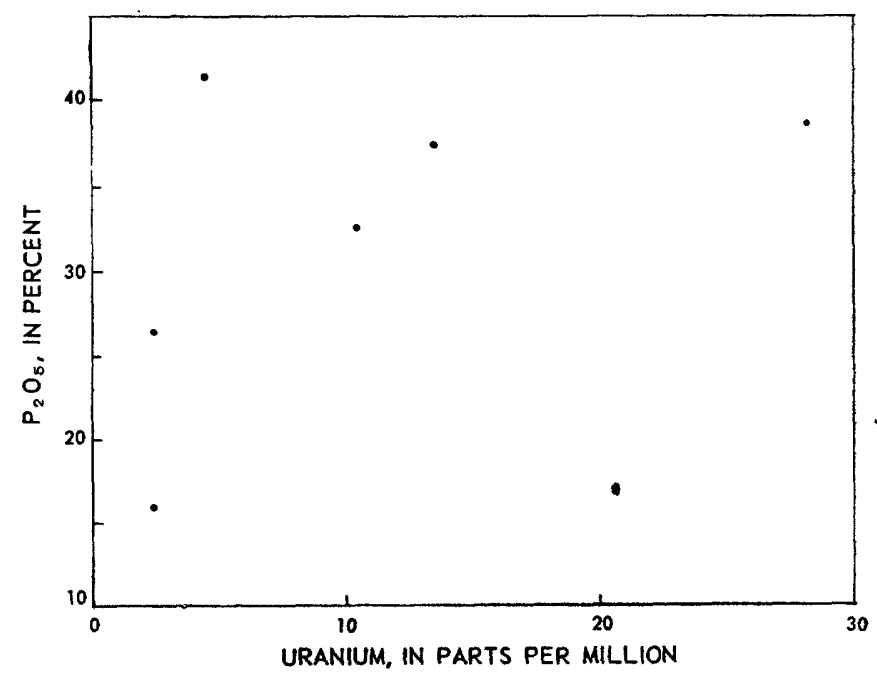

Figonm 4.-Relation of uranium to $\mathrm{P}_{2} \mathrm{O}_{3}$ in Mona Island cave phosphorites. 
$\mathrm{OH}$, and (presumably) U for Ca. That there are so few analyses of the required precision available for such comparisons is in itself a reflection of the generally recognized lack of uranium in phosphate deposits of continental origin. Nevertheless, the facts that secondary uptake of fluorine and uranium are codependent and related to the same geological process and time of emplacement seem indicated by figure 5 , in which the

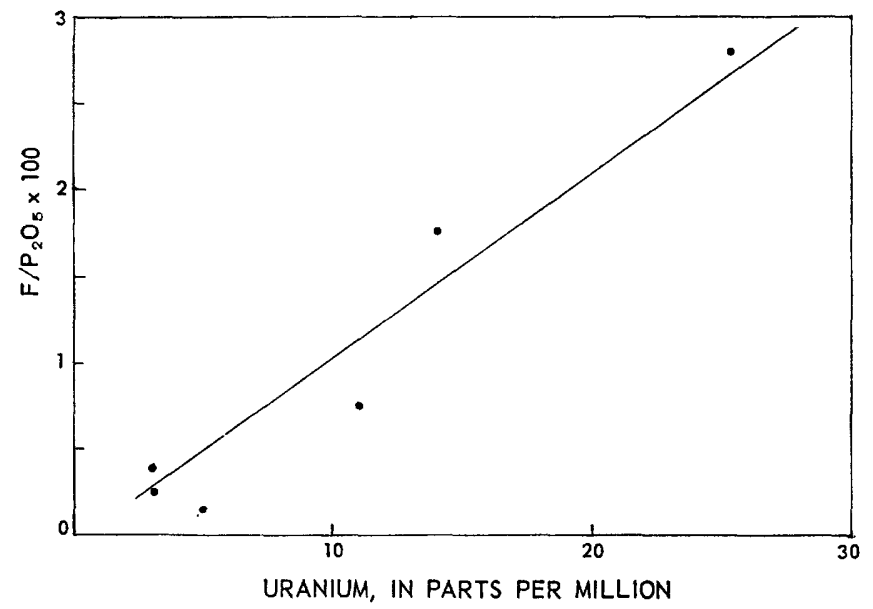

Frever 5.-Relation of uranium to fluoridation in Mona Island cave phosphorites.

admittedly few points exhibit a trend that originates at the point of zero content for both percent of fluoridation and uranium content.

Similar accord between uranium content and the percent of fluorine of Cenozoic bones, in which the fluorine is unquestionably of secondary origin, has been noted in studies of Oakley $(1955 \mathrm{a}, \mathrm{b})$.

If we note also that marine apatite nodules of recent origin contain appreciable uranium (table 5), it seems evident that the large marine phosphorites derive much, if not all, of their uranium from the ocean water at the time of their formation.

\section{PROBLEMS OF OCCURRENCE OF URANIUM IN PHOSPHORITE}

\section{POSSIBLE MODES OF OCCURRENCE}

Two large problems are posed by the analyses given in table 5. In what form and manner does uranium occur in phosphorites? How may its variations within the same deposits or among different deposits of essentially similar material be explained? Thus, the apatite nodules from Florida and Morocco are compositionally and petrographically quite similar, yet those from Morocco contain 2 to 3 times as much uranium. Isolated pebbles from the Land Pebble field contain as much as 0.2 percent of uranium in contrast to the normal concentration.
To explain the nature of uranium in phosphates several mechanisms may be postulated. The uranium may be present in a separate phase such as $\mathrm{UO}_{2}, \mathrm{UF}_{4}$, or $\mathrm{Ca}\left(\mathrm{UO}_{2}\right)_{2}\left(\mathrm{PO}_{4}\right)_{2} .8 \mathrm{H}_{2} \mathrm{O}$ (autunite). It may be present as isolated $\mathrm{U}^{+4}$ ions or $\left(\mathrm{UO}_{2}\right)^{+2}$ radicals, chemically adsorbed on surfaces or internal discontinuities (Hendricks and Hill, 1950). It may be present by structural substitution of $\mathrm{U}^{+4}$ in apatite as proposed by several investigators (Michael Fleischer, oral communication, 1949; McKelvey and Nelson, 1950; Davidson and Atkin, 1953; Goldschmidt, 1954) on the grounds of theoretical plausibility in view of the fact that the ionic radii of $\mathrm{U}^{+4}(0.97 \mathrm{~A})$ and $\mathrm{Ca}^{+2}(0.99 \mathrm{~A})$ (Green, 1953) are virtually identical. Lastly, it may be substituted structurally in apatite as $\left(\mathrm{UO}_{2}\right)^{+2}$ since it has been demonstrated that the uranyl radical will be abstracted from solution by glycol-ashed bone. Such uranium uptake occurs by displacement of two moles of calcium per mole of uranium and also renders surface phosphate $" * * *$ nonexchangable to the extent of two moles per mole of uranium." (Neuman and others, $1949 a ; 1949 b)$. These are puzzling facts for divalent uranyl. Moore (1954) has shown that phosphate can also remove appreciable $\left(\mathrm{UO}_{2}\right)^{+2}$ from cold water solution and that the extracted uranium cannot be washed out.

\section{ABSENCE OF URANIUM MINERALS}

It is a fact of signal importance that uranium minerals are virtually unknown in phosphorites. Uranyl phosphates and vanadates are common in other deposits and they are readily found by virtue of their habit as highly colored "paints" and the fact that many of the species fluoresce brilliantly, thus allowing detection of pinpoint disseminations. Yet these minerals have been noted in only three or four local concentrations in phosphorites (Altschuler and others, 1956; Arambourg and Orcel, 1951; McKelvey and others, 1955).

In the Bone Valley formation, the mineral autunite was found in a single layer of leached and altered rock, 2 feet long and 6 inches wide. It occurred in thin square tablets with perfect (001) and prominent (010) cleavages. Its indices are $\mathrm{N}_{\omega}=1.603 \pm 0.002$ and $\mathrm{N}_{\epsilon}=1.585 \pm 0.002$. Flakes give a uniaxial figure and show blue to violet interference colors when tilted. The mineral shows a bright emerald-green fluorescence on exposure to light of $3650 \mathrm{~A}$ wave length and fainter fluorescence of the same color at 2537 A. X-ray data showed the mineral to be autunite and the optical properties, although not characteristic of ideal autunite, are nevertheless attributable to autunite as described by Fairchild (1929) for synthetic materials. 
Within the leached rock in which it occurs, the autunite coats cavities or is scattered throughout the porous cement. The mineral is absent from the interior of solid pebbles. In addition, phosphorite completely free of autunite (established by lack of fluorescence after powdering), but from the same rock, contains appreciable uranium and the autunite was found to account for only 5 percent of the total uranium in the rock. Thus, even where their presence is established, uranium minerals are of secondary origin and too insignificant to account for all of the uranium present.

\section{RELATION OF URANIUM CONTENT TO COMPOSITION OF PHOSPHORITE}

In efforts to understand the occurrence and variation of uranium in phosphorites, as well as to concentrate it for commercial use, many attempts have been made to correlate it with physical and chemical properties of apatite and phosphorite. Materials from the Bone Valley and Phosphoria formations and from the Moroccan deposits have been fractionated according to their variation in specific gravity, magnetism, color, luster, and particle size. None of these separations led to any positive or consistent correlation with uranium. This is not surprising, however, as it is not to be expected that uranium present in the order of $0.0 \mathrm{X}$ or $0.00 \mathrm{X}$ percent, or 1 atom per several thousand unit cells of apatite, could sensibly alter the properties of the host rock.

\section{FLUORESCENCE AND URANIUM CONTENT}

The property of fluorescence is a notable exception, however, and it was found that a consistent relation could be observed between intensity of fluoresence and uranium content within certain samples. In table 7,

TABLE 7.-Comparison of fluorescence and uranium content in composite samples of apatite nodules from the Bone Valley formation, Boyette mine, Florida

[Analyst, Harry Levine]

\begin{tabular}{l|r|r}
\hline Fluorescence color & Percent $U$ & \multicolumn{1}{c|}{$\begin{array}{c}\text { Number of } \\
\text { samples }\end{array}$} \\
\hline Yellow _ & $0.017-0.021$ & 2 \\
Yellow to brown & .009 & 1 \\
Pink or peach & $.006-010$ & 2 \\
Purple or lavender & $.003-006$ & 4 \\
\hline
\end{tabular}

uranium analyses are given for composite samples of apatite nodules hand-picked on the basis of their fluorescence under ultraviolet light of $3650 \mathrm{~A}$ wavelength.

Each of the composite samples in table 7 consisted of many pellets or pebble fragments, and the fluorescence was characteristic of the entire pellet, or pebble, rather than pinpoint or spotty. The correlation of increased uranium content with enhanced fluorescence is, therefore, further indication of the absence of separate uranium phases in phosphorites, even below the limits of microscopic detection, as it illustrates a change in an inherent property of the host mineral, apatite.

\section{LACK OF PREFERENTIAL SOLUTION OF URANIUM}

In solution studies of rock from the Bone Valley and Phosphoria formations with nonoxidizing solvents such as sulfuric, phosphoric, and citric acids, it was found that the percent of uranium extracted was always proportional to the percent of $\mathrm{P}_{2} \mathrm{O}_{5}$ extracted. This result was attained whether the samples were slimes or crushed pebbles, whether calcined or treated raw, and with highly acid solutions or with small volumes of dilute weak acid (Igelsrud and others, 1948, 1949).

It seems evident that uranium in phosphate deposits cannot be accounted for by discrete uranium phases, by absorption, or by loosely adsorbed ions, radicals, or phases. This is indicated by three lines of evidencethe lack of uranium minerals, the fluorescence of uraniferous apatite, and the inability to concentrate or separate uranium by physical or chemical means in the laboratory.

\section{RELATION OF URANIUM TO $\mathbf{P}_{\mathbf{2}} \mathbf{0}_{5}$}

Most investigators have found that uranium varies approximately as $\mathrm{P}_{2} \mathrm{O}_{5}$ content in phosphate deposits but that a close correlation does not exist between the two. The Moroccan deposits illustrate both the general accord and the lack of detailed agreement. Figure 6 is a scatter diagram in which $\mathrm{P}_{2} \mathrm{O}_{5}$ is plotted against $\mathrm{U}$ for 18 samples representing the average daily production from various beds and locations in the Oulad-

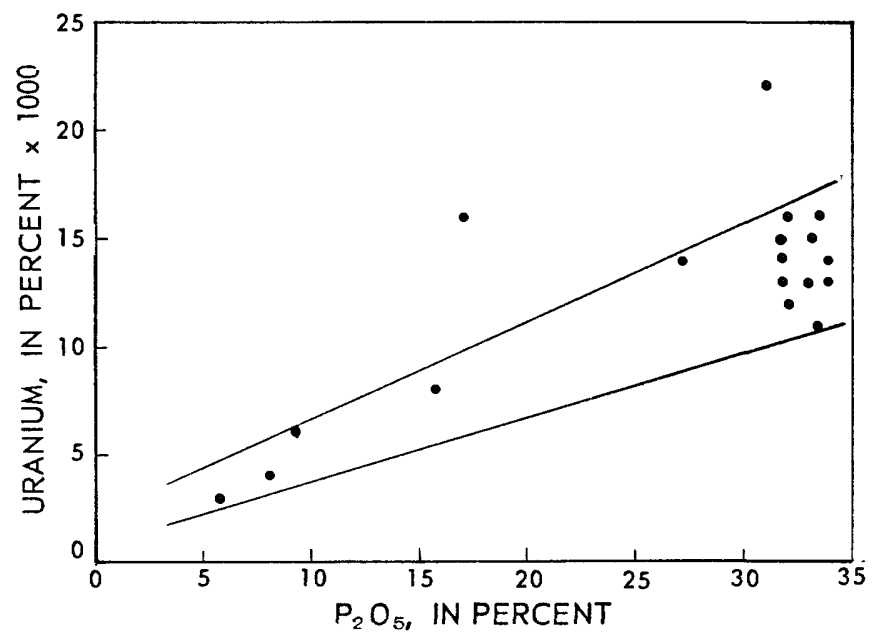

Figure 6.-Relation of uranium to $\mathrm{P}_{2} \mathrm{O}_{5}$ in phosphates from OuladAbdoun Basin, French Moroceo. 
Abdoun Basin. They thus represent large tonnages. The tendency for the two factors to be related is apparent from the plot, in which most of the points fall between narrow limits, bounding a region of welldefined slope. However, when only high-grade samples are studied (those grouping closer together and containing more than 0.011 percent uranium in figure 6) more scattering is noted.

The approximate dependence of uranium on phosphate content is to be expected on two different grounds:

1. Phosphorites are notably devoid of separate uranium mineral phases.

2. Uranium is intimately associated within apatite as revealed by lack of preferential solution and by fluorescence.

Furthermore, the other mineral constituents of the major phosphorites, generally clays, carbonates, and quartz, almost universally contain less than 0.001 percent of uranium. A few samples of clay contain more, but such clays have been phosphatized or contain primary, admixed apatite, and their phosphatic material can be dissolved with dilute nitric acid leaving a pure clay residue that is relatively uranium-free. The ratio of uranium to phosphate dissolved is the same as in the apatite associated with such clays.

In view of the essentially exclusive association of uranium with the apatite within unweathered phosphorites, almost perfect positive correlation between uranium and any parameter of apatite content would be expected within a group of related rocks. However, detailed studies of the relations among uranium and the other chemical constituents of apatite show frequent and striking departures from pronounced positive correlation. The prevailing relation in the Bone Valley formation is for coarse pebble to be richer in uranium and poorer in $\mathrm{P}_{2} \mathrm{O}_{5}$ content than the finer pebble. Cathcart (1956) demonstrated this relation and found that a moderate negative correlation $(-0.64)$ exists between $\mathrm{P}_{2} \mathrm{O}_{5}$ and uranium for samples of +150 mesh pellets and pebbles throughout the Land Pebble Field. Such
TABLE 8.-Size distribution and uranium contents of pelletal phosphates from Khouribga, French Morocco

[Analyst, Frank Cuttitta]

\begin{tabular}{r|r|r|r}
\hline Sieve size (mesh) & $\begin{array}{r}\text { Diameter } \\
\text { mm }\end{array}$ & $\begin{array}{r}\text { Welght } \\
\text { percent of } \\
\text { fraction }\end{array}$ & \multicolumn{1}{|c|}{$\begin{array}{l}\text { Uranium } \\
\text { percent }\end{array}$} \\
\hline 32 & 0.630 & 2.0 & 0.015 \\
44 & .437 & 2.3 & .015 \\
& .210 & 35.2 & .016 \\
325 & .149 & 28.4 & .015 \\
& .074 & 25.9 & .016 \\
& & 2.9 & .015 \\
\hline
\end{tabular}

1 The finest fraction contains clay diluent.

negative correlation has not been found elsewhere and indeed, even within the land pebble field deposits containing 10 percent $\mathrm{P}_{2} \mathrm{O}_{5}$ will contain less uranium than deposits with 20 percent $\mathrm{P}_{2} \mathrm{O}_{5}$. In the Moroccan deposits uranium is uniformly distributed through all size grades, as table 8 demonstrates. In the Phosphoria formation McKelvey and Carswell (1956) have demonstrated that maximum uranium content is regionally associated with areas of thickset and highest grade phosphate accumulation.

An equilibrium condition may exist between apatite and uranium in sea water during the precipitation of apatite; however, such equilibrium may vary greatly with time and marine environment. Thus, assemblies of data from different parts of the same formation may represent a variety of different equilibria and an average of such varied groups of data may have the effect of masking, rather than demonstrating, a universal relation. The work of Thompson $(1953,1954)$, who has explored the relation of uranium to apatite composition in a series of closely spaced, contiguous samples from the Phosphoria formation, possibly overcomes this difficulty. Her results are reproduced in table 9.

The results developed, and noted by Thompson, are that samples with a higher average uranium content show the best positive correlation with $\mathrm{P}_{2} \mathrm{O}_{5}$ content.

TABLE 9.-Correlation coefficients among $e U, \mathrm{P}_{2} \mathrm{O}_{3}, \mathrm{~F}, \mathrm{CO}_{2}$, and organic matter in samples of the Phosphoria formation (Thompson, 1959, 1954)

\begin{tabular}{|c|c|c|c|c|c|c|c|c|c|}
\hline \multirow{2}{*}{ Locality and sample } & \multirow{2}{*}{$\begin{array}{l}\text { Number } \\
\text { of } \\
\text { samples }\end{array}$} & \multicolumn{2}{|c|}{ eU $\times 10^{8}$ percent } & \multicolumn{2}{|c|}{$\mathbf{P}_{2} \mathrm{O}_{6}$ percent } & \multicolumn{4}{|c|}{ Correlation coefficients } \\
\hline & & Range & Average & Range & Average & $\mathrm{eU} / \mathrm{P}_{2} \mathrm{O}_{8}$ & eU/organic & $\mathrm{CO}_{2} / \mathrm{P}_{2} \mathrm{O}_{4}$ & $\mathrm{~F} / \mathrm{P}_{2} \mathrm{O}_{6}$ \\
\hline Brazer Canyon WT 605, 604 & 51 & $8-29$ & 13 & $12-34$ & 26 & +0.2 & -0.2 & +0.52 & +0.98 \\
\hline Brazer Canyon WT 603 & 24 & $7-36$ & 20 & $3-34$ & 26 & +.8 & -.6 & +.93 & +.99 \\
\hline Coal Canyon WT 700 & 12 & $6-16$ & 31 & $1-34$ & 20 & +.9 & -.7 & +.98 & +.99 \\
\hline Trail Canyon WT 365 & 26 & $4-28$ & 8 & $20-35$ & 30 & +1 & +.5 & +.29 & +.95 \\
\hline 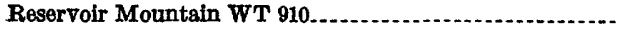 & 31 & $7-30$ & 16 & $31-36$ & 34 & -.2 & -.6 & n. d. & n. d. \\
\hline
\end{tabular}


The same samples also show the best positive correlation between $\mathrm{CO}_{2}$ and $\mathrm{P}_{2} \mathrm{O}_{5}$ and the best negative correlation with organic matter. All samples showed excellent positive correlation between $\mathrm{F}$ and $\mathrm{P}_{2} \mathrm{O}_{5}$. This last is expectable as the phosphate mineral is a carbonate-fluorapatite and although free fluorite is common in the Phosphoria, it was not detected in any of these samples (Thompson, 1954). One is struck by the spread in the correlations between eU and $\mathrm{P}_{2} \mathrm{O}_{5}$, and by the fact that the samples from Reservoir Mountain, which show negative and very poor correlation, do not differ greatly in average eU content from samples WT 603 which show strong positive correlation.

Equally arresting is the fact that the two groups of samples showing best correlations do so for all of the constituents compared. This suggests that all of the factors are covarying with the same set of environmental conditions and therefore that these two sets of samples have sustained the least postdepositional change. This follows from the fact that the rocks are polymineralic, containing organic matter, carbonates, and apatite as separate phases. As the relations among these in primary marine deposition would differ considerably from those that would prevail under subaerial weathering or metamorphism, the $\mathrm{CO}_{2}$, eU, and $\mathrm{P}_{2} \mathrm{O}_{5}$ correlations in sets of samples WT603 and WT700 may all reflect the carbonate-fluorapatite content in relatively unaltered rock. On the other hand the poor correlation between $\mathrm{CO}_{2}$ and $\mathrm{P}_{2} \mathrm{O}_{5}$ in the other sets may reflect secondary alteration in terms of the highly mobile calcite, and, as during such alteration uranium may be added or subtracted, and apatite may be affected, eU- $\mathrm{P}_{2} \mathrm{O}_{5}$ correlations are also notably poorer.

\section{MARINE VERSUS GROUND WATER ORIGIN OF URANIUM IN PHOSPHORITE \\ GENERAL STATEMENT AND VIEW}

Evidently, comparisons based on composition alone do not yield consistent explanations of the occurrence of uranium in phosphorites. Davidson and Atkin (1953) after surveying the bewildering variation in the available chemical data, concluded that in most instances the uranium in phosphorites is postdepositionally emplaced from percolating ground water as a proxy for calcium. This explanation adequately accounts for the uranium content of isolated bones and some guano deposits, and may account for some part of the uranium of other materials, but it is not tenable when applied to the preponderant occurrences-the marine phosphorites, plus the phosphatic shales and limestones.
The theory of ground-water percolation as the major source and mode of uranium emplacement demands that uranium content increase significantly with age. Lénoble, Salvan, and Ziegler (1952) observe that radioactivity increases with age in the Moroccan deposits. However, they stress the minute nature of the variation, and Guntz (1952), in discussing the same deposits, emphasizes their regularity of grade, which suggests to him uranium coprecipitated during sedimentation. It is significant also that the Senonian Moroccan apatite contains appreciably more uranium than apatite from the Permian Phosphoria, which is much older, and has had a more varied history.

In a comparison of the radioactivity of nine Polish phosphorites, ranging in age from Cambrian to Upper Cretaceous, Piénkowski (1953) noted that $" * * *$ the most ancient phosphorites were feebly radioactive; whereas the activity increases progressively in the younger formations," (table 10). Piénkowski did not

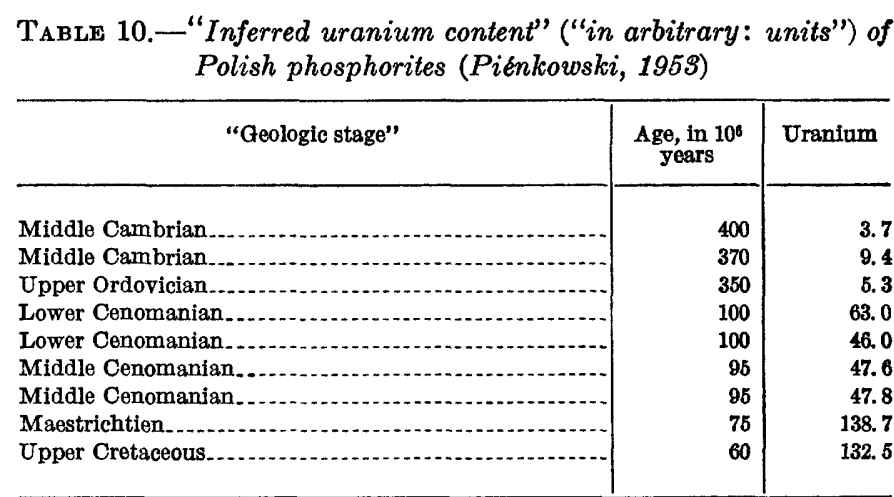

explain this relation and, as his data fall into three groups rather than continuously over the time span examined, we believe that a progressive change has not been significantly demonstrated. It is germane to the present discussion, however, that large steplike increases in uranium content occur in the younger phosphorites. This contradicts the theory that ground water is the major source of uranium in phosphorites.

\section{EVIDENCE OF YOUNG PHOSPHORITES AND SUBMARINE NODULES}

Regarding the question of marine versus groundwater origin, it is most noteworthy that apatite nodules dredged from the Gulf of California (table 5), contain as much uranium as the pellets from the Permian Phosphoria and Miocene Hawthorn formations. The Phosphoria and Hawthorn materials have been exposed subaerially, whereas the nodules from southern California waters have remained submerged and, although 
they may have undergone submarine reworking, most of them are thought to be of Quaternary age (Dietz and others, 1942).

Further information on the magnitude of oceanderived uranium in recent deposits may be gleaned from the analyses of slighty phosphatic materials dredged from the Gulf of Mexico during recent U. S. Geological Survey studies (H. R. Gould, written communication). Table 11 presents 10 of many hundreds of similar analyses. The samples represent contemporary accumulations of very slightly phosphatized shell and marl, and it is most significant that the ratio of uranium to phosphate in them far exceeds that of most high-grade marine phosphorites.

TABLE 11.-Phosphate and uranium contents of bottom samples from the Gulf of Mexico

[Analyses from U. S. Geological Survey Laboratory (Gould, H. R., written communication, 1953)]

\begin{tabular}{|c|c|c|c|c|c|c|}
\hline Sample & $\underset{\text { (fathoms) }}{\text { Depth }}$ & $\begin{array}{l}\text { North } \\
\text { latitude }\end{array}$ & $\begin{array}{c}\text { West } \\
\text { longi- } \\
\text { tude }\end{array}$ & $\underset{\text { (per- }}{U}$ & $\begin{array}{l}\mathrm{P}_{2} \mathrm{O}_{5} \\
\text { (per- } \\
\text { cent) }\end{array}$ & Description \\
\hline 105916 & 24 & $26^{\circ} 50.1^{\prime}$ & $83^{\circ} 16.1^{\prime}$ & 0.0002 & 0.13 & Shell sand. \\
\hline $105917 \ldots$ & 30 & $26^{\circ} 52.1^{\prime}$ & $83^{\circ} 33.5^{\prime}$ & .0002 & .11 & Shell sand. \\
\hline 105918 & 35 & $26^{\circ} 50.7^{\prime}$ & $83^{\circ} 46.1^{\prime}$ & .0002 & .11 & Algal sand. \\
\hline 105819 & 45 & $26^{\circ} 50.1^{\prime}$ & $83^{\circ} 57.9^{\prime}$ & .0002 & .09 & Algal sand. \\
\hline $105920_{-}$ & 63 & $26^{\circ} 51.5^{\prime}$ & $84^{\circ} 08.0^{\prime}$ & .0003 & .28 & Shell sand. \\
\hline $105921 \ldots$ & 100 & $26^{\circ} 52.2^{\prime}$ & $84^{\circ} 32.7^{\prime}$ & .0002 & .24 & $\begin{array}{l}\text { Foraminiferal sand and } \\
\text { shell. }\end{array}$ \\
\hline $105922 \ldots$ & 80 & $26^{\circ} 34.8^{\prime}$ & $84^{\circ} 15.0^{\prime}$ & .0002 & .20 & $\begin{array}{l}\text { Foraminiferal sand and } \\
\text { shell }\end{array}$ \\
\hline $105923 \ldots$ & 62 & $26^{\circ} 31.3^{\prime}$ & $83^{\circ} 57.9^{\prime}$ & .0002 & .18 & $\begin{array}{l}\text { Foraminiferal sand and } \\
\text { shell. }\end{array}$ \\
\hline 105924 & 7 & $26^{\circ} 18.7^{\prime}$ & $83^{\circ} 12.5^{\prime}$ & .0001 & .09 & Shell sand. \\
\hline $105925 \ldots$ & $81 / 2$ & $26^{\circ} 20.0^{\prime}$ & $83^{\circ} 22.1^{\prime}$ & $<.0005$ & .08 & Quartz sand. \\
\hline
\end{tabular}

Table 12 lists analyses and $\mathrm{U} / \mathrm{P}_{2} \mathrm{O}_{5}$ ratios of representative large deposits and individual samples of apatite, all of materials not demonstrably enriched subaerially.

The unusually high $U / \mathrm{P}_{2} \mathrm{O}_{5}$ ratio of the phosphatized bottom samples may be due to some special regional condition such as oceanographic factors affecting $\mathrm{CO}_{2}$ concentration which in turn can influence uranium solubility (Piggot and Urry, 1941; Bachelet and others, 1952), or perhaps unusual uranium concentrations in the sea water of the Gulf as a result of the Pleistocene weathering and leaching of the land pebble phosphate deposits.

Although the mechanism causing the high uranium concentration in the phosphatized shells and marls can only be conjectured, the fact remains that enrichment of such magnitude can occur in a purely marine environment. Some nodules dredged from coastal Cali-
TABLE 12.-Relative contents of uranium and $\mathrm{P}_{2} \mathrm{O}_{5}$ in marine phosphorites

\begin{tabular}{l|r|r|r}
\hline Sample & $\begin{array}{c}\mathrm{U} \\
\text { (percent) }\end{array}$ & $\begin{array}{c}\mathrm{P}_{2} \mathrm{O}_{8} \\
\text { (percent) }\end{array}$ & $\mathrm{U} / \mathrm{P}_{2} \mathrm{O}_{5}$ \\
\hline \multicolumn{3}{c|}{ Gulf of Mexico bottom samples 1 } \\
\hline & $\begin{array}{r}0.0001-0.0003 \\
0.0002\end{array}$ & $\begin{array}{r}0.09-0.28 \\
0.185\end{array}$ & $\begin{array}{r}1 / 925 \\
\text { Arbitrary mean }\end{array}$ \\
\hline
\end{tabular}

Pacific Ocean off southern California 2

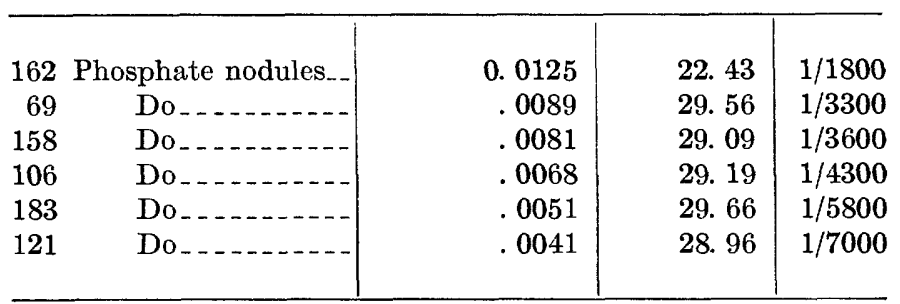

Hawthorn formation, Florida ${ }^{3}$

\begin{tabular}{|c|c|c|c|}
\hline $\begin{array}{c}\text { Primary apatite pellets } \\
\text { Do }\end{array}$ & $\begin{array}{r}0.0075 \\
.0045\end{array}$ & $\begin{array}{l}37 \\
37\end{array}$ & $\begin{array}{l}1 / 4950 \\
1 / 8200\end{array}$ \\
\hline \multicolumn{4}{|c|}{ Khouribga, French Morocco ${ }^{4}$} \\
\hline $\begin{array}{l}\text { Phosphorite } \\
\text { Do } \\
\text { Do } \\
\text { Do }\end{array}$ & $\begin{array}{r}0.015 \\
.014 \\
.013 \\
.013\end{array}$ & $\begin{array}{l}\text { 33. } 0 \\
\text { 33. } 6 \\
\text { 33. } 0 \\
\text { 33. } 6\end{array}$ & $\begin{array}{l}1 / 2200 \\
1 / 2400 \\
1 / 2540 \\
1 / 2580\end{array}$ \\
\hline \multicolumn{4}{|c|}{ Land pebble field, Florida 5} \\
\hline $\begin{array}{l}\text { Clastic apatite compos- } \\
\text { ites } \\
\text { Do } \\
\text { Do Do } \\
\text { Do }\end{array}$ & $\begin{array}{r}0.018 \\
.014 \\
.010 \\
.010 \\
.009\end{array}$ & $\begin{array}{l}\text { 30. } 7 \\
33.4 \\
34.5 \\
35.2 \\
33.0\end{array}$ & $\begin{array}{l}1 / 1760 \\
1 / 2380 \\
1 / 3450 \\
1 / 3520 \\
1 / 3660\end{array}$ \\
\hline
\end{tabular}

1 See table 11.

${ }_{2}^{2} \mathrm{P}_{3} \mathrm{O}_{5}$ and sample numbers from Dietz, Emery, and Shepard (1942); uranium on the same sample splits by R. S. Clarke, Jr.

${ }_{3}$ Uranium by R. S. Clarke, Jr.; $\mathrm{P}_{2} \mathrm{O}_{5}$, assumed average for such pure apatite nodules, will yield conservative $U$ concentration.

4 Daily production averages at four stations in Oulad-Abdoun Basin, French Morocco.

5 Weighted averages of nodules and pebbles from five areas each representing a minimum of 100,000 long tons of phosphorite (data converted from Catheart, fig. $3 \mathrm{~A}, 1956)$.

fornia waters contain as much uranium relative to phosphate as the relatively rich large deposits of Florida and French Morocco.

\section{NECESSITY OF GEOLOGIC INTERPRETATION}

Neglecting the trivial occurrences in guano and bone, spectacular as the actual uranium concentration in the 
latter may be, it can be stated that most of the uranium in marine sedimentary phosphorite is of marine origin. The neutral to basic nature of apatite makes it susceptible to alteration under the prevailing acidities of most vadose waters. It is thus to be expected that the primary marine uranium may be redistributed by various secondary processes, as indicated by conflicting and varied relations of uranium to composition in the same and among different deposits, and by the evidence of laboratory uptake of uranium by bone and phosphorite. Therefore, it appears that the uranium content of apatite can be explained only in terms of the total geologic history of the deposits. In the following sections of this report a number of specific deposits are examined, and the geologic processes that have governed their uranium content are elucidated in hopes of developing a set of principles to explain the range and variation of uranium in most phosphorites.

\section{PRINCIPLES GOVERNING URANIUM DISTRIBUTION IN PHOSPHORITES}

\section{URANIUM IN PHOSPHORITE DURING WEATHERING}

\section{florida llaNd pebBle phosphates-generar}

GEOLOGY

The land pebble phosphates of Florida present an opportunity to study apatite in a variety of geologic circumstances and thus to evaluate its uranium content in terms of both petrography and petrology. These deposits are mainly in the Bone Valley formation of Pliocene age (Cathcart and others, 1953) and subordinately in the underlying Hawthorn formation of early and middle Miocene age (MacNeil, 1947). The surface of the Hawthorn is irregular, its rock is solution-pitted, and it contains many small and large slumps, within which the overlying Bone Valley thickens (Cathcart, 1950). The Hawthorn was exposed and weathered during late Miocene time, developing an irregular topography and accumulations of phosphatic residue containing primary apatite nodules, inherited as such from the Hawthorn, and secondarily phosphatized limestone pebbles. During a period of Pliocene marine transgression this residuum of the Hawthorn was reworked into the unconformably overlying Bone Valley formation, with additions of quartz, clay, and probably phosphate (Altschuler and others, 1956).

The Bone Valley formation is about 30 feet thick and consists of two units (fig. 7). A pebbly and clayey sand characterized by graded bedding comprises the lower two-thirds and is the unit mined. Grading upward from this is a massive-bedded, less phosphatic quartz sand, which together with a surface mantle of quartz sands, is discarded as overburden during mining operations.

The upper part of the Bone Valley formation has been leached, altered to aluminum phosphates, and secondarily enriched in uranium in a widespread, transgressive zone that, though discontinuous, underlies several hundred square miles in the land pebble district. This aluminum phosphate zone is the result of lateritic weathering and ground water alteration, and sections through it exhibit a progressive variation in mineral content and texture (fig. 7). In typical sections pebbles of carbonate-fluorapatite still occur at the base, incipiently leached and altered. The calcium-aluminum phosphates crandallite and millisite are found in the middle of the zone. At the top, the aluminum phosphate wavellite predominates (Altschuler and others, 1956).

In the land pebble deposits we may thus study and contrast the uranium contents of sedimentary apatite of the following types:

1. Simple structureless nodules from the Hawthorn formation.

2. Nodules from Hawthorn that have been reworked into the Bone Valley and are thus in a second cycle of sedimentation.

3. Simple pebbles of phosphatized limestone from the Bone Valley formation.

4. Complex reworked pebbles from the Bone Valley formation illustrative of several subcycles of sedimentation.

5. Leached and altered pebbles.

6. Secondarily enriched pebbles.

\section{ILLUSTRATION OF LEACHING}

In a conglomerate rock composed of pebbles resting in a matrix of finer grained material, the pebbles usually cause zones of increased permeability in adjoining matrix by disturbing the packing arrangement of the smaller grains. These areas would be zones of better circulation and as such would be the preferred loci of any leaching or enrichment that occurs within the rock. Thus the uranium, or the secondary phosphate, might be distributed according to the texture within the phosphate pebble rock. Graton and Fraser (1935) described this type of control and noted its influence in gold and copper deposition.

To test the influence of texture on the distribution of uranium, six pebbles were selected and analyzed for percent of uranium in zones from the surface to the center. The pebbles were selected from the aluminum phosphate zone of the Bone Valley formation and the data given in table 13 are described according to the sampling scheme shown in figure 8 . 


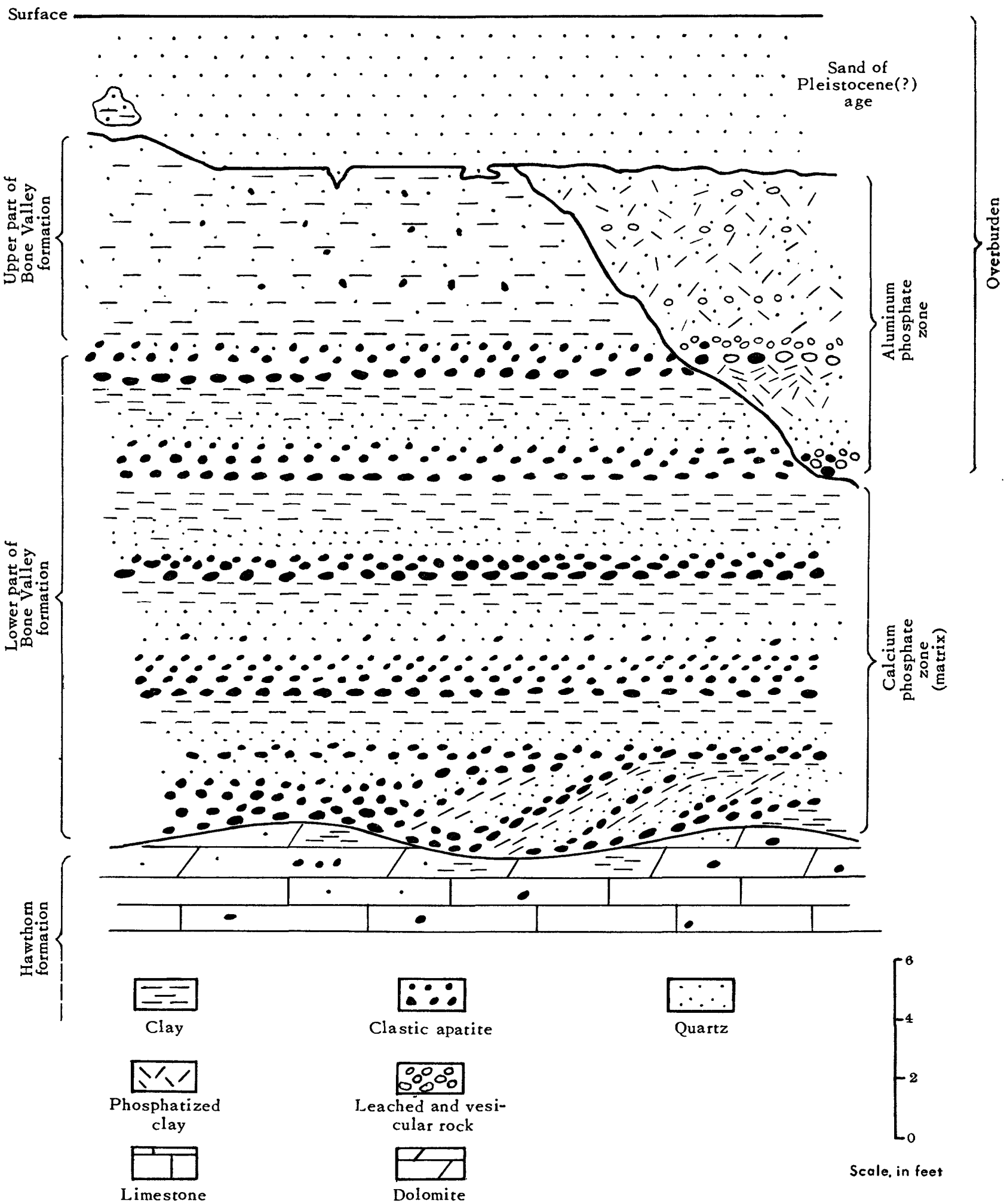

Fradre 7.-Stratigraphic relations in the Land Pebble phosphate field, Florida. 


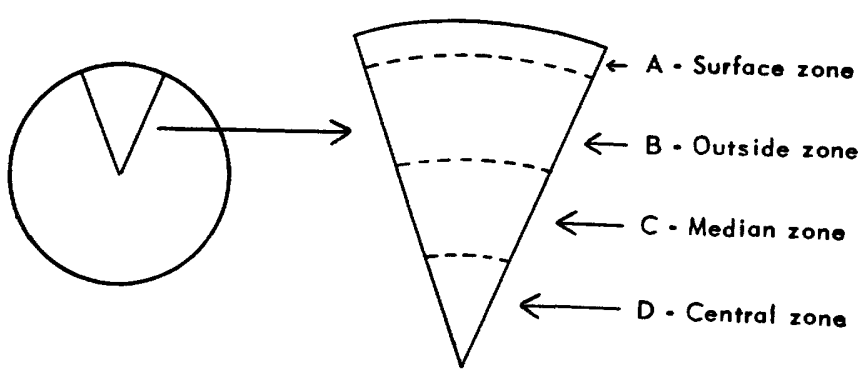

Figuri 8.-Sampling scheme used for study of uranium distribution in pebbles.

Table 13 reveals a striking increase in uranium content from the surface inward, in all of the pebbles. Except for zone B in pebble 1, this increase is constant and of steep, although nonuniform gradient, and values at the center are easily 100 percent higher than those at the outside.

This graded distribution suggests leaching of the uranium from phosphate pebbles of originally more uniform richness. It is significant that the sharpest increase in uranium content is in every case, between zones $\mathrm{A}$ and $\mathrm{B}$. Inside the $\mathrm{B}$ zone the increase is smaller. This is precisely what would be expected as the surface zones would be more easily attacked.

It is evident that subaerial leaching can effect large changes in the primary uranium contents of marine deposits. The leaching illustrated above occurred after deposition, in the course of ground-water alteration. Leaching can presumably be equally effective during subaerial transport and reworking of similar materials. In this latter case the leaching would not be confined primarily to conglomeratic material and would probably show greater effects in the finer materials, as these have a greater ratio of surface to volume. That leaching did affect the rock's uranium content could probably be demonstrated by the same means or by the use of autoradiography.
POSTDEPOSITIONAL ENRICHMENT

ALUMINUM PHOSPHATE ZONE-IATERITIC WEATHERING AND SUPERGENE ENRICHMENT

The Bone Valley formation yields instructive examples of enrichment as well as of leaching. Unaltered phosphorite in the lower part of the Bone Valley contains an average of 0.008 percent of uranium and 10 to 15 percent of $\mathrm{P}_{2} \mathrm{O}_{5}$. In contrast, typical rock from the aluminum phosphate zone has 0.012 percent of uranium and 8 to 12 percent of $\mathrm{P}_{2} \mathrm{O}_{5}$-roughly a two-fold enrichment in the phosphatic fraction.

There is much variation in the composition and uranium content of the aluminum phosphate zone. Nevertheless, the distribution of uranium within it closely follows the distribution of calcium (fig. 9). The uranium content is greatest in the base of the zone, declines gradually toward the middle of the zone, and is relatively low in the upper half. The zone of basal enrichment corresponds to the zone containing apatite pebbles, and analyses for uranium in pebbles, cements, and mineral concentrates within the entire zone show that the apatite pebbles are the richest uranium components of the zone and that the pebbles in the base of the zone are richer than those in the middle. Figure 10 illustrates these relations and shows the contribution of 
TABLE 13.-Chemical analyses showing distribution of uranium within phosphate pebbles

Corrections were made for the percentage of quartz in each portion tested. Analyses from U. S. Geological Survey laboratory]

\begin{tabular}{|c|c|c|c|}
\hline Pebble & Zone & Percent U & Remarks \\
\hline 1 & $\begin{array}{l}\text { A } \\
\text { B } \\
\text { C } \\
\text { D }\end{array}$ & $\begin{array}{r}0.011 \\
.023 \\
.020 \\
.021\end{array}$ & $\begin{array}{l}\text { Selected at random; a small flattened } \\
\text { spheroid } 2.5 \text { by } 2 \text { by } 1 \mathrm{~cm} \text {. The pebble } \\
\text { is a microconglomerate, made up of } \\
\text { precipitated phosphate, phosphate pel- } \\
\text { lets, quartz grains, and still smaller } \\
\text { pebbles of similar composition. The } \\
\text { other pebbles are similar in character. }\end{array}$ \\
\hline 2 & $\begin{array}{l}\text { A } \\
\text { B } \\
\text { C } \\
\text { D }\end{array}$ & $\begin{array}{l}.007 \\
.026 \\
.028 \\
.033\end{array}$ & Selected at random. \\
\hline 3 & $\begin{array}{l}\text { A } \\
\text { C }\end{array}$ & $\begin{array}{r}.020 \\
.028\end{array}$ & $\begin{array}{l}\text { Selected because of high fluorescence, a } \\
\text { small fractured pebble of originally high } \\
\text { roundness; original central portion is } \\
\text { now exposed surface, hence only surface } \\
\text { and median zone were sampled. }\end{array}$ \\
\hline 4 & $\begin{array}{l}\text { A } \\
\text { C }\end{array}$ & $\begin{array}{l}.011 \\
.032\end{array}$ & Selected because of high fluorescence. \\
\hline 5 & $\begin{array}{l}\text { A } \\
\text { B } \\
\text { D }\end{array}$ & $\begin{array}{r}012 \\
.019 \\
.026\end{array}$ & $\begin{array}{l}\text { Selected because of high fluorescence; sur- } \\
\text { face encrustation of brown phosphate } \\
\text { which was obviously deposited by circu- } \\
\text { lating solutions since some of it occurs } \\
\text { as a circular ridge outlining the area of } \\
\text { previous contact with another pebble. }\end{array}$ \\
\hline 6 & $\begin{array}{l}\text { A } \\
\text { B } \\
\text { C }\end{array}$ & $\begin{array}{l}.007 \\
.013 \\
.015\end{array}$ & Selected because of high fluorescence. \\
\hline
\end{tabular}

the various textural components to uranium content of the total rock in a section through the aluminum phosphate zone.

Additional evidence of secondary enrichment may be obtained by comparing the uranium contents of composite samples of pebbles from rock of originally identical petrography above and below the base of the aluminum phosphate zone. Pebbles from within the zone were found to contain 0.056 percent of uranium in contrast to their anologues just outside the zone which had only 0.023 percent of uranium. Furthermore, individual pebbles from the base of the zone contain as much as 0.25 percent of uranium. Concentrates of crandallite and millisite from the middle of the aluminum phosphate zone generally contain from 0.03 to 0.05 percent of uranium. In contrast, pure wavellite, the dominant mineral in the upper part of the zone, contains only 0.002 to 0.004 percent of uranium. Despite the low uranium content in wavellite the upper part of the aluminum phosphate zone generally contains from 0.005 to 0.01 percent of uranium (fig. 9). This fact has led some authors to assume that «*** radioactivity is as characteristic of wavellite $* * *$ as it is of apatite ***" (Davidson and Atkin, p. 13). However, most analyses of the wavellitic part of the aluminum phosphate zone reveal the presence of trace to minor amounts of calcium (fig. 9), reflecting the presence of small amounts of crandallite that can be seen microscopically, and in which much of the uranium resides.

The aluminum phosphate zone is commonly underlain by ferruginous hardpans that are relict of old ground-water levels. It is also characterized by secondary leaching and vesicularity and by mineral changes that progress vertically through the section. At the bottom, the zone is characterized by softened and bleached apatite pebbles. In the middle, holes represent former pebbles, and crandallite has replaced clay cement and has been deposited from solution within pebble cavities. Upward, wavellite needles replace the clayey crandallite deposits and the original clay cement (pl. 11, figs. $A, B$ ). This alteration has caused a depletion of $\mathrm{CaO}$, silicate, and some phosphate in the upper part, where there is a complementary increase in $\mathrm{Al}_{2} \mathrm{O}_{3}$ (fig. 9) combined in acid aluminum phosphate, wavellite $\left(\mathrm{Al}_{3}(\mathrm{OH})_{3}\left(\mathrm{PO}_{4}\right)_{2} .5 \mathrm{H}_{2} \mathrm{O}\right)$. Wavellite yields downward to intermediate $\mathrm{Ca}-\mathrm{Al}$ phosphates (crandallite and millisite), and finally to the basic apatite at the base of the zone. These features imply a history of lateritic alteration by acid ground

\section{EXPLANATION OF PLATE 11}

Frgures $A, B$. Phosphatic quartz sandstone from the aluminum phosphate zone, Florida. $A$, Plane polarized light; $B$, crossed nicols. Original clay cement (a) is now highly porous and almost completely replaced by lathlike wavelite. The large and smoothly bounded cavity (b) is the site of a previous apatite pebble that has been removed by leaching. The cavity is now rimmed and partially filled by layered crandallite, with admixed kaolinite and goethite. The concavely stratified bottom filling of the cavity indicates the downward direction of the original weathering solutions.

$C, D$. Photograph and autoradiograph of fossil bone, both $\times 11 / 2$.

$E, F$. Autoradiographs of reworked and first cycle pebbles. 
GEOLOGICAL SLIRVEY
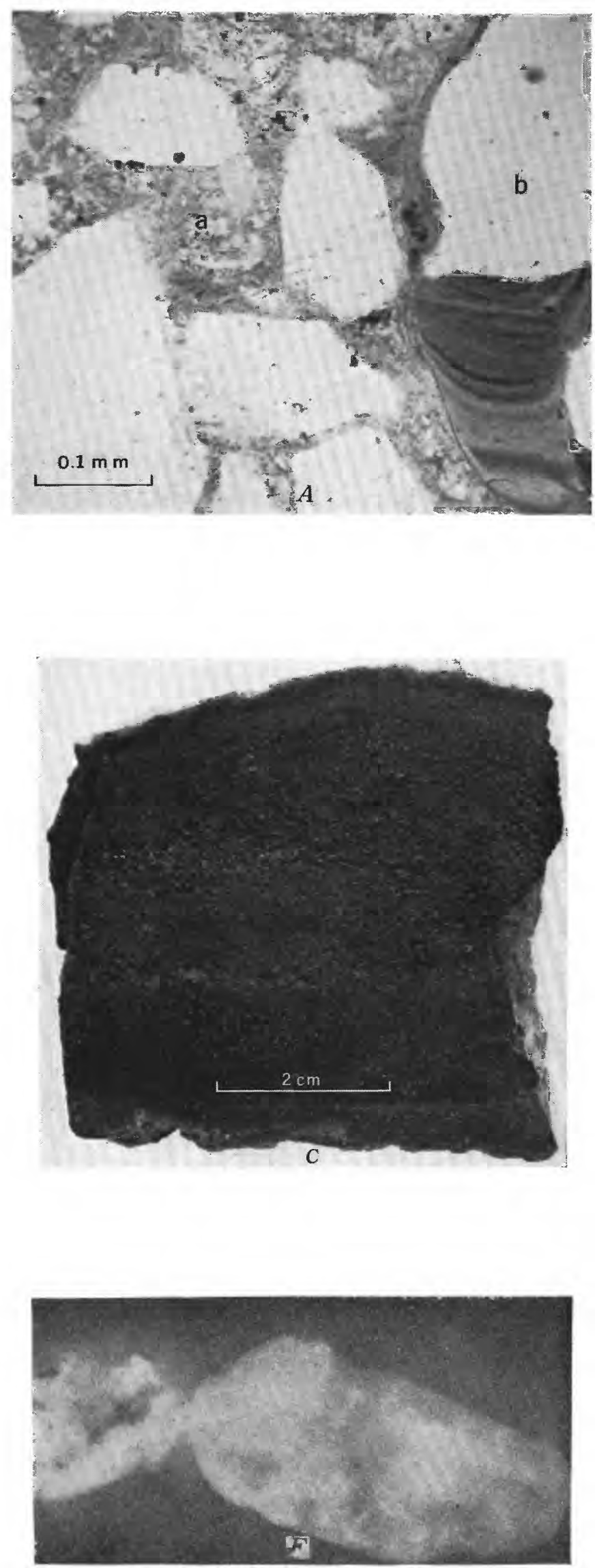

professional PAPER 314 PLATE 11
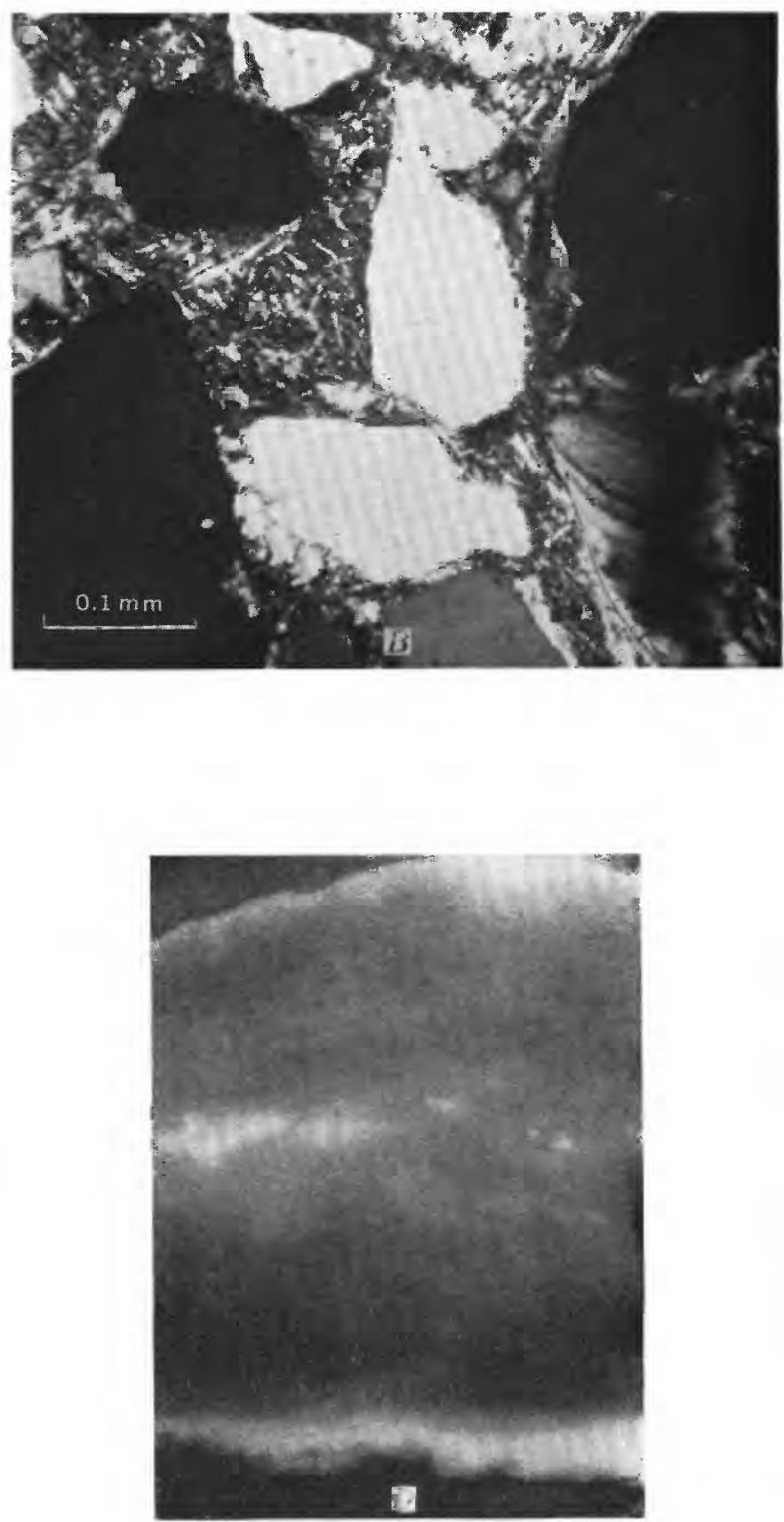

E 


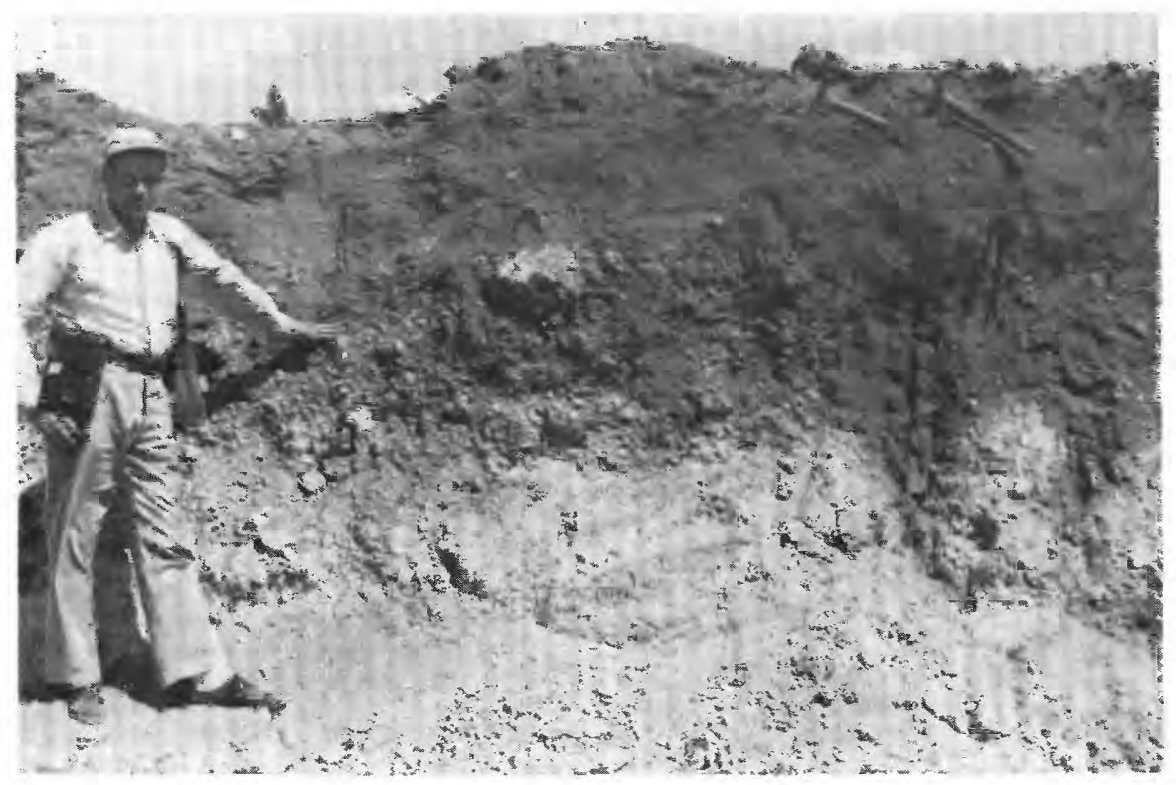

A.-Details of contact between aluminum phosphate zone (white) and orerlying ferruginous sand mantle, Clear Springs Mine, Bartow, Fla. Photo illustrates the rubbly and concretionary nature of the weathered zone and the irregular and deeply embayed contact, which, with the residual concretions visible in the overlying sands, rereals the previonsly higher level of contact.

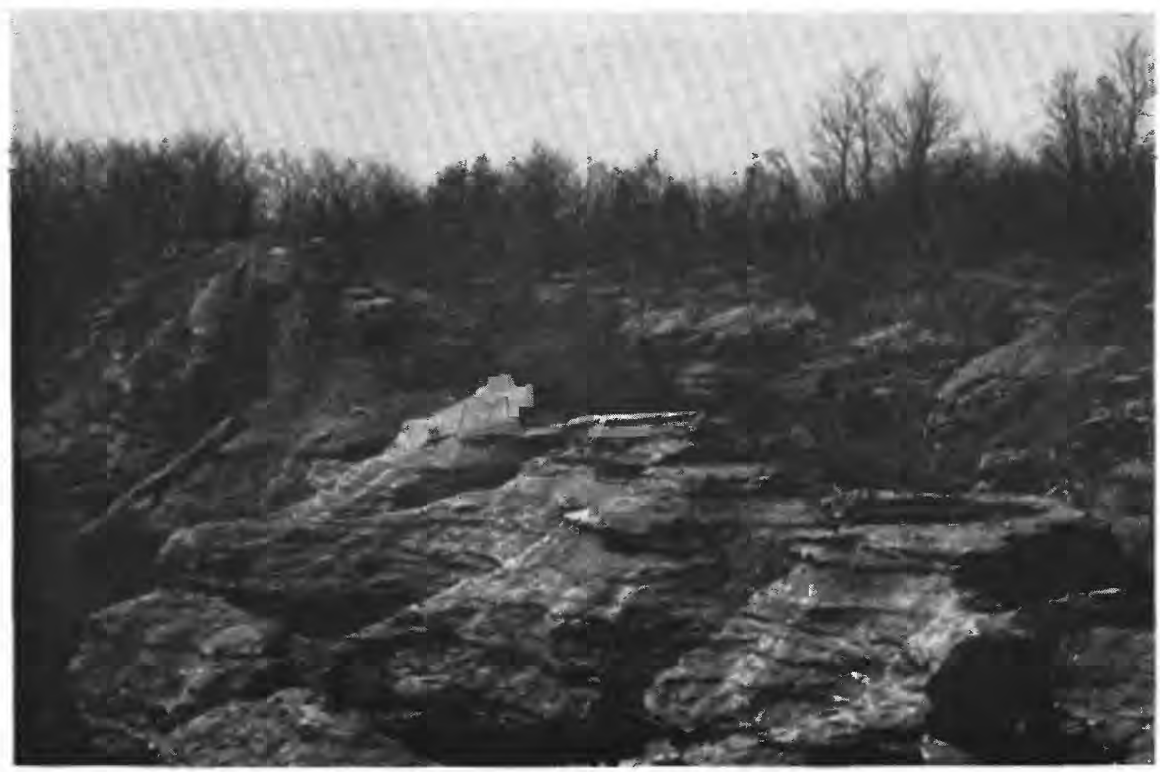

B.-Mined out area of Tennessee brown-rock phosphates, Akin mine, Columbia, Tenn., showing control of rectangular joint system in the origin and distribution of the residual phosphates. Pinnacles and blocks of unaltered, crossbedded limestone of the Bigby formation occur in rows flanking the valleys created by weathering and mining along the master joints. The subsidiary joint set may be seen dividing and separating individual blocks. Phosphate has been mined from all of the depressions. 

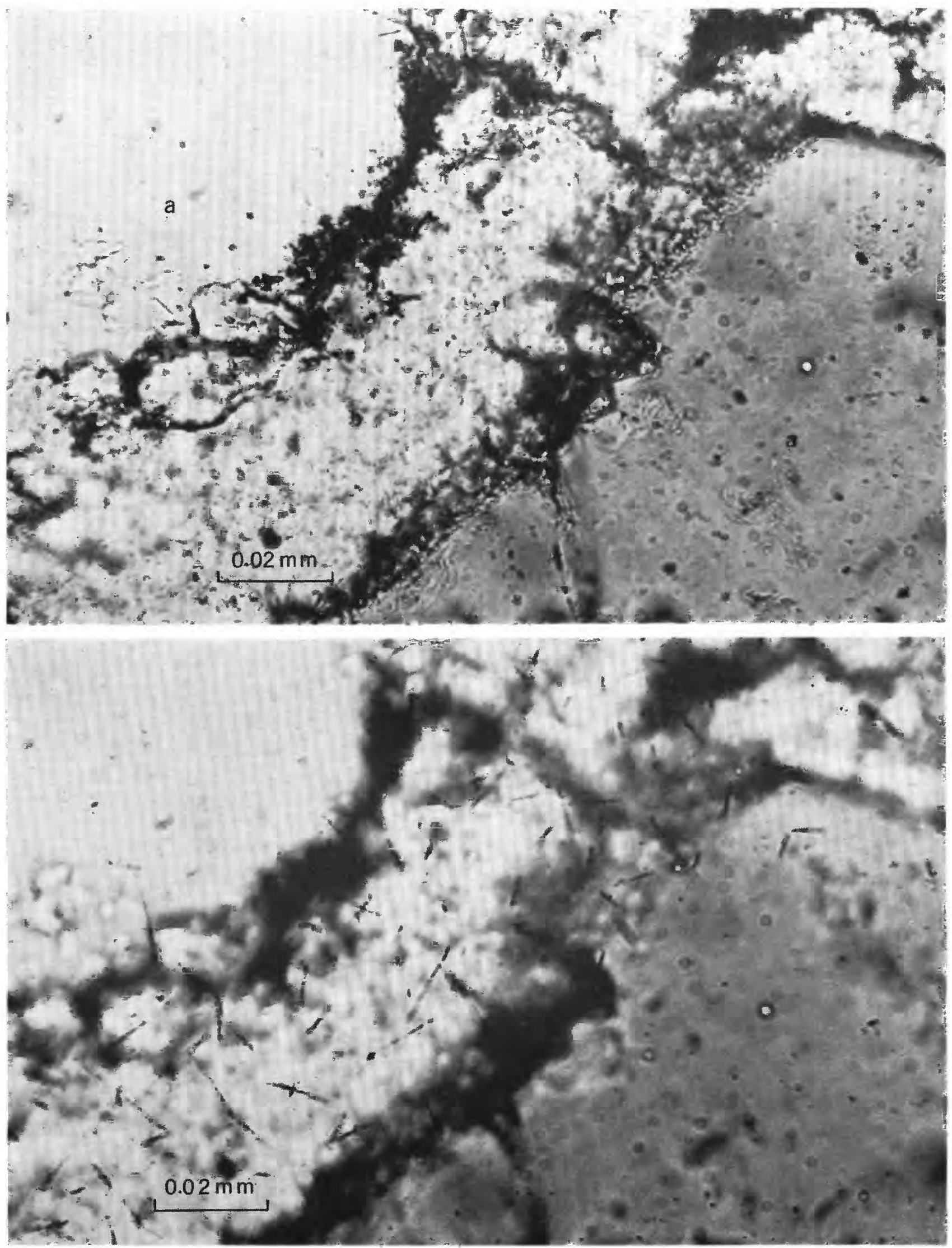

Photomicrographs of arkosic sandstone with carbonate-fluorapatite cement from the Gas Hills area of Wyoming. A, Thin section alone, plane polarized light, showing quartz grains (a) and intergranular cement (b). B, Photomicrograph focused in the plane of the superimposed nuclear emulsion to show alpha tracks emanating from the apatite cement. 



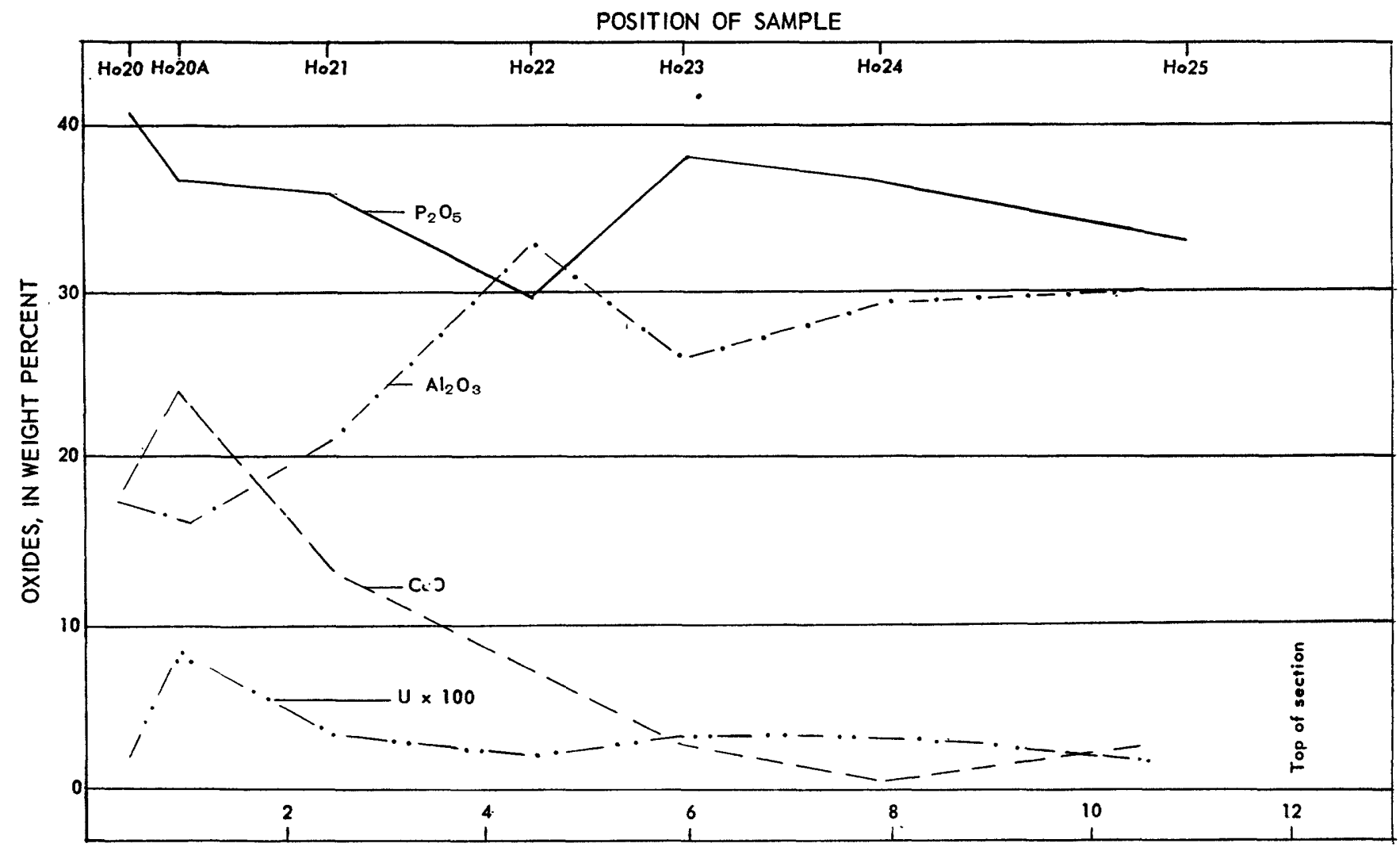

POSITION IN STRATIGRAPHIC SECTION, IN FEET

Fravan 9.-Distribution of oxides through aluminum phosphate zone at Homeland mine, Homeland, Fla.

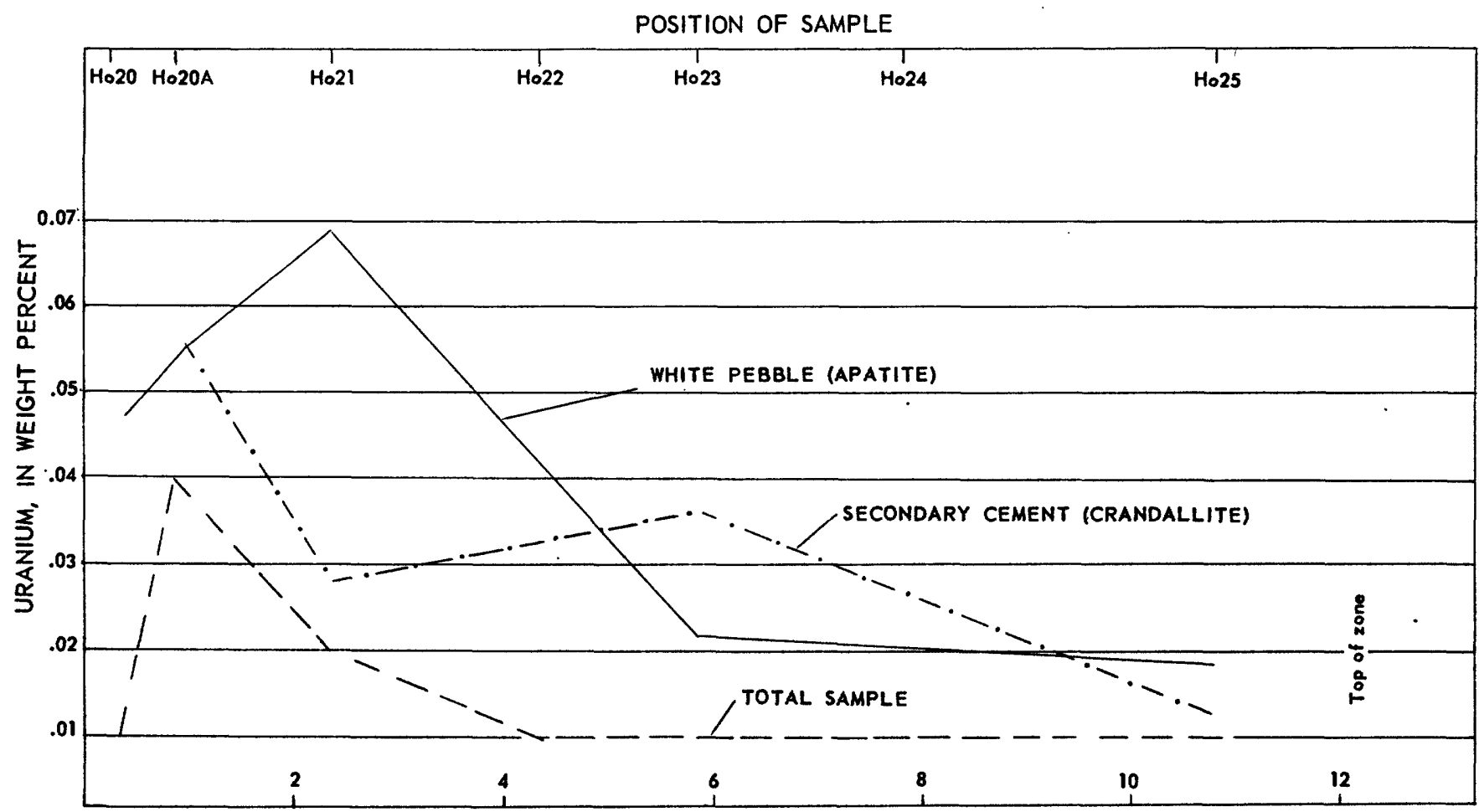

POSITION IN STRATIGRAPHIC SECTION, IN FEET

Fradrm 10.-Uranium distribution in various textural components at Homeland mine, Homeland, Fla. 
water. The pattern of uranium distribution parallels that of downward leaching and alteration. Uranium is liberated during the leaching and solution of apatite pebbles in the upper part of the zone. It is kept soluble in the acid ground water and emplaced in the highly porous, partly leached apatite pebbles at the base of the zone where the acids would be neutralized by the yet unaltered calcium phosphate. The correspondence between the curves for $\mathrm{CaO}$ and uranium (fig. 9) and the basal enrichment of uranium in apatite (fig. 10) suggest that the uranium substitutes for calcium in the apatite structure. This presupposes that the uranium in apatite is tetravalent, a supposition which is discussed on page 69.

The theory of supergene enrichment presented above demands that originally there was 2 or 3 times more apatite than now occurs in the aluminum phosphate zone. This prerequisite is not supported by the obvious field relations as, in unaltered exposures, it is possible to see a primary stratigraphic change to a less phosphatic clayey sand, from lower to upper Bone Valley (fig. 7). There is evidence, however, that an originally thicker section was available to provide the present enrichment (pl. 12, fig. $A$ ). Briefly, the contact between the upper part of the Bone Valley and the surface mantle of loose quartz sand is irregular in detail and the sands of both zones are virtually identical in size, sorting, and heavy-mineral content. Therefore, a large part of the loose sand mantle is a residue of weathered Bone Valley and the present contact is a lowered one.

\section{THE COOPER MARI-RESIDUAL ENRICHMENT}

Unusual and widespread subaerial enrichment of uranium in apatite also occurs in the phosphate deposits of the Cooper marl in the vicinity of Charleston, S. C. Being composed principally of limestone, the Cooper marl is only slightly phosphatic. However, it has been postdepositionally weathered and phosphatized, and in the exposures in the vicinity and along the banks of the Ashley River, between Drayton and Middleton Gardens, the deposits are characterized by a thin uppermost zone of nodular induration. The induration results in irregular, discontinuous encrustation and the rock is replaced by secondary phosphate. It is obvious that the process was accompanied by moderate leaching-the indurated fragments that are loose or easily broken out of this zone are marked by cavernous irregularity and conspicuous molds of pebble and fossils, although its fine texture is similar to that of the unweathered underlying rock.

The unaltered Cooper marl "*** commonly contains about 75 percent lime carbonate and about 2 percent lime phosphate," (Rogers 1913, p. 187). The
Cooper marl was exposed and eroded during Oligocene to Miocene time and later exposed and weathered during Pliocene to Pleistocene time (Rogers, 1913, and Malde, in press). During the last period of weathering the calcite was both leached out of the section and replaced by apatite. The fact that apatite could reprecipitate as a stable phase during weathering suggests that the ground water alteration was only mildly acid. This is further indicated by the absence of aluminum phosphates or even the intermediate calcium-aluminum phosphates, despite the fact that the region contains appreciable clay.

An immediate consequence of the re-forming of apatite at the site of alteration is the refixation of any uranium mobilized by prior solution. This establishes a pattern of residual enrichment. The pattern may be construed as follows:

1. Mildly acid ground water dissolves calcite and apatite.

2. Some, if not much, of the phosphoric acid in solution is immediately neutralized by reaction with the remaining calcite of the marl, producing secondary apatite.

3. Most of the uranium in solution is taken up by the newly formed apatite.

This scheme indicates a disproportionate enrichment of uranium as a result of its preferential uptake in the apatite structure. It has been possible to develop conclusive data in support of this in the phosphates of the Cooper marl. Malde in his study of the Cooper marl noted that $" * * *$ the uranium content is rather uniform, ranging between 0.001 and 0.005 percent, rarely as much as 0.007 percent and averaging about $0.003 . "$

In contrast to these observations of the prevailing tenor in the unaltered marl, analyses in table 14 illustrate the overall magnitude of enrichment in the hardpan collected in the area between Rantowles Creek and

TABLE 14.-Examples of phosphate- and uranium-enriched hardpan in Cooper marl near Charleston, S. C.

\begin{tabular}{|c|c|c|}
\hline Locality & Percent U 1 & $\underset{\mathrm{P}_{2} \mathrm{O}_{5}{ }^{2}}{\mathrm{Percent}}$ \\
\hline $\begin{array}{l}\text { Magnolia Gardens, exposure on west bank of } \\
\text { Ashley River }\end{array}$ & 0.048 & 22. 1 \\
\hline $\begin{array}{l}\text { Andrews, borrow pit on west side State High- } \\
\text { way } 161 \text {, one-half mile north of Andrews... }\end{array}$ & .061 & 28. \\
\hline $\begin{array}{l}\text { Ashley River banks, west bank at road from } \\
\text { Olive Branch Church }\end{array}$ & .048 & 24. \\
\hline $\begin{array}{l}\text { Ashley River banks, east bank } 1.25 \text { miles south } \\
\text { of Lambs. }\end{array}$ & .038 & \\
\hline $\begin{array}{l}\text { Bulow Mines, } 2 \text { miles southwest of Fort Bull } \\
\text { on Fort Bull-Red Top Highway }\end{array}$ & .043 & \\
\hline $\begin{array}{l}\text { Micah Jenkins Nursery, U. S. Highway } 61 \text {, } \\
\text { one-half a mile west of St. Peters Church.- }\end{array}$ & .087 & \\
\hline
\end{tabular}

1 Analyst, G. J. Daniels.

Analyst, A. R. Schrenk. 
Ashley River. The analyses show enrichment of both apatite and uranium, especially of uranium. The selective enrichment of uranium is shown by comparing analyses of unaltered marl and the overlying fragments of cavernous hardpan from the same exposure (table 15). It is significant that the enrichment in $\mathrm{P}_{2} \mathrm{O}_{5}$ is only 6 -fold whereas that in uranium is 15 -fold.

TABLE 15.-Comparison of phosphatized and primary Cooper marl from Lambs, S. C. (300 yards above old railroad terminus on west bank of Ashley River)

\begin{tabular}{|c|c|c|}
\hline Material & Percent $\sigma^{1}$ & $\underset{\mathrm{P}_{2} \mathrm{O}_{3}{ }^{2}}{\mathrm{Percent}}$ \\
\hline (a) Unaltered marl_ & 0.005 & 4. 0 \\
\hline (b) Phosphatized hardpan & .074 & 25. 9 \\
\hline (c) Enrichment factor (b/a) & 15 & 6 \\
\hline
\end{tabular}

1 Analyst, G. J. Daniels.

Analyst, A. R. Schrenk.

Another illustration of preferential uptake of uranium during weathering of apatite is obtained by comparing different nodules from the same hardpan samples of phosphatized Cooper marl. At several localities contiguous fragments differed markedly in color, from dark brown to light tan or gray. The lighter color was ascribed to the bleaching effects of oxidative subaerial weathering. On the assumption that the lighter fragments had thus undergone more of such weathering, light and dark fragments were analyzed separately with the thought that differences in uranium content would be shown and that differences in other constituents would reveal the relation of the uranium content to weathering history. Results of chemical and of semiquantitative spectrographic analysis of the same samples are given in tables 16 and 17.

The two samples, obtained from localities about 4 miles apart, are representative of hardpan and weather- ing conditions over a wide area ; nevertheless, the chemical changes illustrated by the two comparisons are remarkably uniform for secondary subaerial processes. The spectrographic analyses show that the differences between the contiguous dark- and light-colored members of each pair are due to weathering. In each pair the relative quantities of silica and aluminum increase and the iron content drops in the light member. The changes are not large and are of comparable magnitude in each pair. The fact that the carbon content is the same for both members of one pair and is even greater in the light-colored member of the second pair in table 16 , proves that the color change was not brought about by oxidation of organic matter as originally supposed. Instead, it is obviously the result of leaching of ferric iron. The persistence of ferrous iron in each case indicates that the leaching was accomplished by reducing solutions, a fact further indicated by the persistence or increase in organic carbon.

It is suggested that mildly acid humate solutions, derived from the organic-rich soils that are common in the Ashley River flood plain, removed the iron by the formation of organo-ferric complexes and thus effected a partition between ferrous and ferric iron. The solutions dissolved out apatite, slight amounts of the other soluble constituents, and calcite. This is demonstrated by the uniform decrease in $\mathrm{P}_{2} \mathrm{O}_{5}$ content in both pairs. This caused a slight residual enrichment in the relatively insoluble constituents, quartz and clay; hence silica and aluminum both increase in the light members (table 17)..$^{2}$ Thus, the light members of each pair reflect substantially more contact with ground water solutions, and during such contact appreciable quantities of uranium were taken out of solution by the

\footnotetext{
2 It is possible that in the Ninemile sample only the relative proportions of Si and $\mathrm{F}$ have been reversed. However, in view of the systematic changes in Fe and $\mathrm{Al}$ being demonstrated for both samples, it is believed that the $S i$ in the light member of the Ninemile sample actually has increased as in the unambiguous case of Lambs.
}

TABLE 16.-Variation of enrichment with weathering in phosphatized Cooper marl, South Carolina

\begin{tabular}{|c|c|c|c|c|c|c|c|}
\hline Location & Sample & \multicolumn{6}{|c|}{ Percent } \\
\hline $\begin{array}{l}\text { Ninemile Station, Southern Railroad, half a mile north- } \\
\text { west of Goodrich, stream bank, east of railroad trestle. }\end{array}$ & $\begin{array}{l}\text { Dark fragment } \\
\text { Light fragment. }\end{array}$ & $\begin{array}{l}0.035 \\
.11\end{array}$ & $\begin{array}{l}27.0 \\
26.9\end{array}$ & $\begin{array}{r}1.04 \\
.57\end{array}$ & $\begin{array}{r}0.40 \\
.38\end{array}$ & $\begin{array}{r}1.04 \\
.40\end{array}$ & $\begin{array}{r}0.5 \\
.5\end{array}$ \\
\hline Roadcut one mile south of Lambs on Charleston road..... & $\begin{array}{l}\text { Dark fragment } \\
\text { Light fragment }\end{array}$ & $\begin{array}{l}.064 \\
.12\end{array}$ & $\begin{array}{l}27.2 \\
25.5\end{array}$ & $\begin{array}{l}.73 \\
.35\end{array}$ & $\begin{array}{l}.34 \\
.38\end{array}$ & $\begin{array}{l}.66 \\
.07\end{array}$ & $\begin{array}{r}.6 \\
1.1\end{array}$ \\
\hline
\end{tabular}

1 The uranium analyses were made on the filtrate of a nitric acid leach. Additional analyses on the total sample indicate that all the uranium occurs in the soluble, phosphatic fraction of the sample. Analyst, G. J. Daniels.

2 Analyst, A. R. Schrenk.
3 Analyst, Alexander Sherwood. (Total iron and FeO determined chemically; $\mathrm{Fe}_{2} \mathrm{O}$ s computed by difference.)

4 Analyst, A. B. Caemmerer. 
TABLE 17.-Semiquantitative spectrographic analyses of phosphatic hardpan from the Cooper marl

[Order of precedence gives relative percent content; thus in the dark member at Nine mile, $\mathbf{F}$ is greater than $\mathbf{S i}$, and $\mathbf{M g}$ is greater than Sr. Analyst, Katherine $\mathbf{E}$ Valentine]

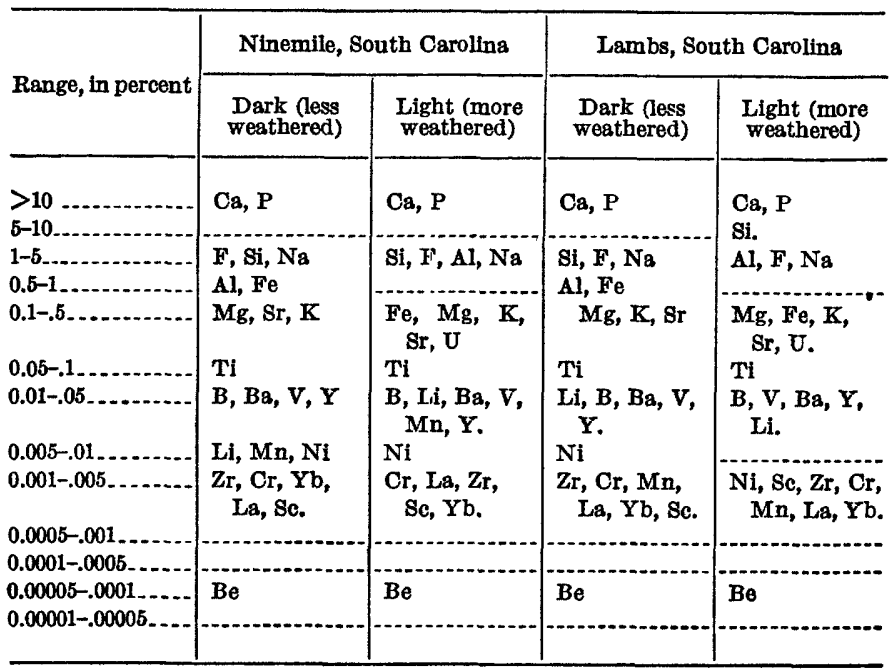

apatite. The fact that the bulk chemical changes are small (for example $\mathrm{P}_{2} \mathrm{O}_{5}$ data and the date table 17) proves that residual enrichment cannot explain the 2to 3-fold uranium enhancement of the light over the dark nodules. Patently, the residually enriched uranium of the nodules throughout the region is frequently augmented by significant additions of uranium from ground water.

\section{CONTRASTING MODES OF ENRICHMENT IN MITD VERSUS INTENSE WEATHFRING}

In comparing uranium distributions within the Bone Valley formation and the Cooper marl, it becomes evident that two largely different patterns of regional enrichment prevail during weathering, despite the fact that the primary mechanism of enrichment is the same, namely, the takeup of uranium from ground water during weathering. The patterns of enrichment are governed by the mineral assemblages which in turn reflect the diverse conditions and environments of weathering. Figure 11 summarizes and contrasts the results.

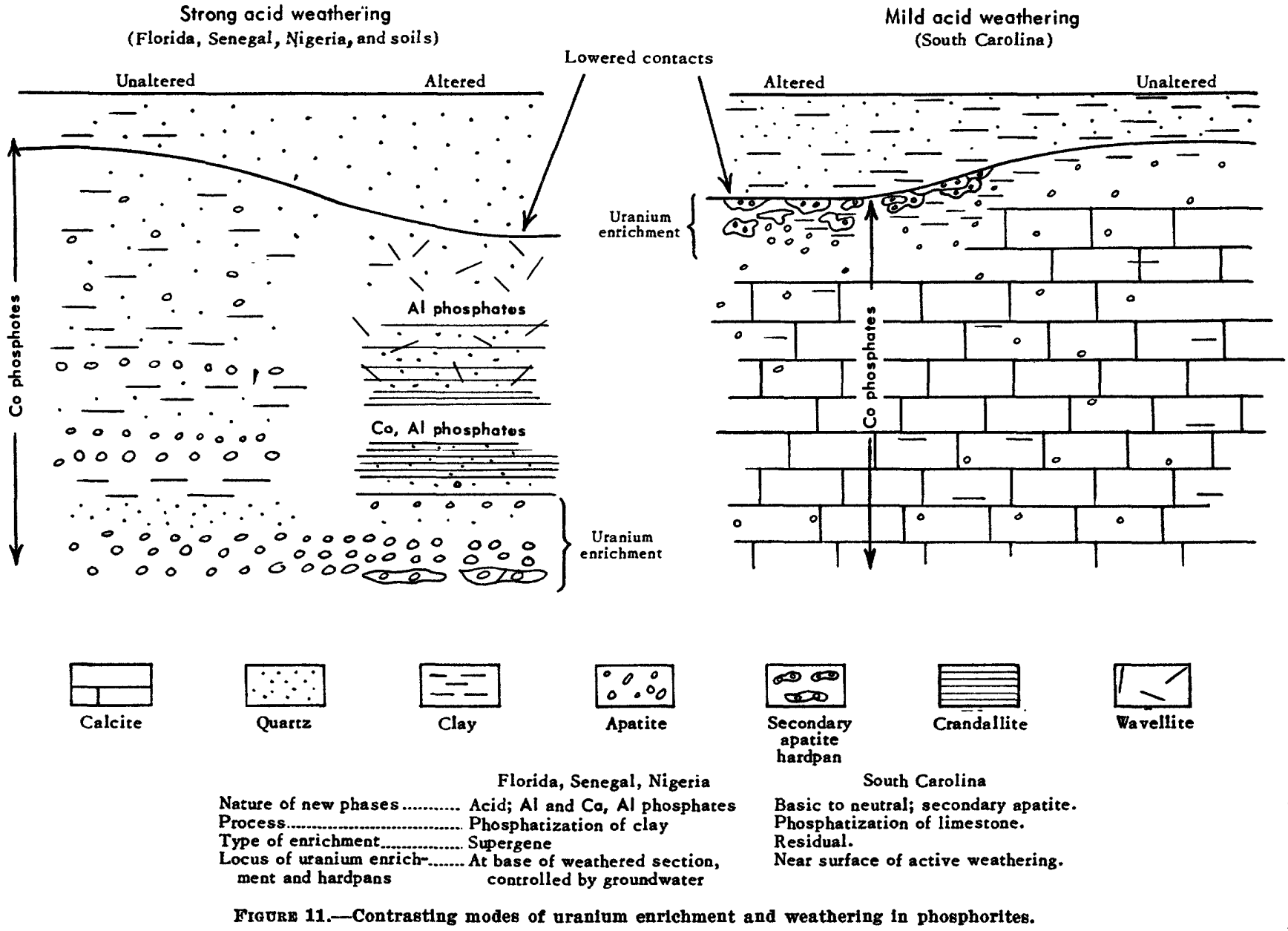


In South Carolina the process is a simple one of simultaneous enrichment of uranium and production of apatite at the zone of weathering. The weathering does not seem to have been very intense-the zone it has affected is quite thin and the mineral transformations are not profound, involving merely the leaching of calcite and apatite and the reprecipitation of apatite. As a result the zone of enrichment, coinciding with the zone of appreciable weathering, is restricted to the uppermost part of the section and migrates only as weathering reduces the rock to inert constituents (fig. 11).

In Florida, and in Senegal (Capdecomme, 1953) and Nigeria (Russ, 1924), the prominence of aluminous phases implies a regimen of highly acid, lateritic weathering such as would be expected in these tropical areas. The development of purely aluminous phosphate (wavellite) in the upper parts of the weathering zone in turn excludes the concentration of uranium, which migrates to where calcic phosphates occur (fig. 11), and, accordingly, uranium content increases progressively down the section, reaching moderate concentration in the crandallite zone and causing a supergene enrichment in the base of the entire zone where weathering is incipient and apatite still abounds.

The deduction of two different intensities of weathering, strongly and weakly acid, from rocks of two different gross petrographies, might be questioned on the grounds that the South Carolina deposit, containing primary calcite, would have so much greater neutralizing capacity than the Florida deposit that acid phases could not be generated. However, it is noteworthy that the Sengal deposits contained limestone and dolomite but were nevertheless altered to crandallite and other aluminum phosphates. In addition it has been shown that the excessive enrichment of some of the Cooper marl nodules must represent ground-water enhancement beyond the pure residual enrichment of adjoining nodules. This ground-water enhancement implies considerable additional ground water seepage; yet the apatite, a basic to neutral compound, has remained as a stable phase despite the fact that clays abound in the overlying marls and metasomatic alteration of apatite to aluminum phosphates is rather common under similar conditions in soils. Presumably the acidity was quite low, as even traces of aluminum phosphates or intermediate phases are absent in the hardpan of the Cooper marl.

\section{BROWN-ROCR PHOSPHATES OF TENNESSEE-RESIDUAI CONCENTRATION}

The brown-rock phosphates of central Tennessee are a prominent example of residual phosphate accumula- tion. They were therefore studied for residual concentration of uranium. The brown-rock deposits occur mainly as a residual blanket surmounting the Bigby formation of middle Ordovician age (Hayes and Ulrich, 1903), a crossbedded limestone in which apatite occurs sparsely concentrated within topset and foreset intercalations, and also weakly disseminated throughout the limestone. The deposits "... occur only in areas where Bigby-Cannon limestone directly underlies the soil ..." (Alexander, 1953) and are absent when mining extends into hillsides where fresh limestone is encountered. It is evident that the deposits were formed during Cenozoic weathering by preferential solution of the limestone (pl. 12, $B$ ). In many areas the residuum occurs as filling of solution-enlarged joints locally known as "cutters." Within such "cutters" it is possible to sample both the weathering concentrate and the adjoining, closely related parent material. ${ }^{3}$ Analyses for one such set of samples from the Akin mine of the Tennessee Valley Authority at Columbia, Tennessee are presented in table 18. The relation of these samples to the stratigraphy is shown in figure 12.

TABLE 18. - $\mathrm{P}_{2} \mathrm{O}_{5}$ and uranium content of weathered and fresh Tennessee phosphates, Akin mine, Columbia, Tennessee

[Analyst, R. S. Clarke, Jr.]

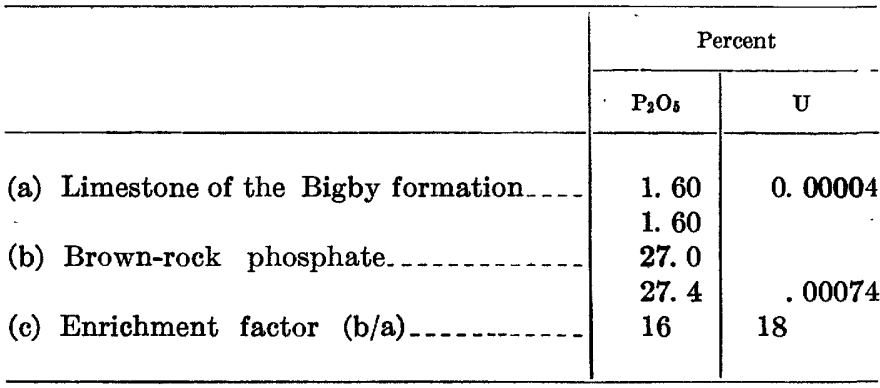

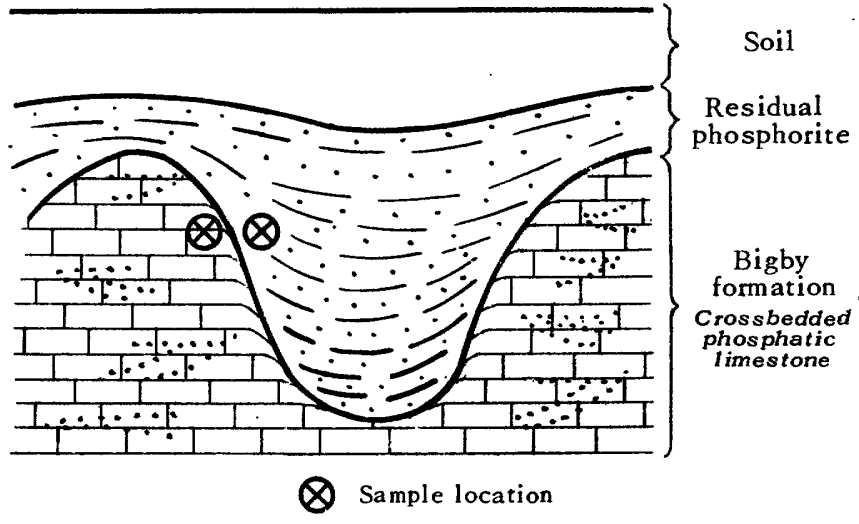

FIGURD 12.-Sample locations $\bigoplus$ for comparison of brown-rock phosphate with parent limestone in Tennessee.

8 Exact stratigraphic equivalence of these samples cannot be assumed due to draping and compaction within the "cutters." 
The figures above demonstrate purely residual enrichment. The differences between the concentration factors of 16 and 18 are negligible in view of the difficulties in analyzing such small quantities of uranium. The striking contrast of the above to results from the South Carolina samples (table 15) where the enrichment factor for uranium is far greater than for $\mathrm{P}_{2} \mathrm{O}_{5}$, serves to emphasize the partly external origin of the ground water enhancement of uranium in the South Carolina deposits.

\section{SECONDARY EMPLACEMENT OF URANIUM IN BONES}

Determinations of the radioactivity and uranium content of bones have been made by several authors, and it can be seen from their publications, and from the analyses in table 5, that bones exhibit the gamut of uranium content in apatite. The highest radioactivity for any apatite material previously reported is by Davidson and Atkin (1953), who listed a specimen of fossil fish from the Old Red sandstone containing 0.55 percent $\mathrm{eU}$. Bowie and Atkin (1956) have shown that the unusual radioactivity of other fossils from the same region and formation is due in appreciable measure to thorium. They show, however, that the thorium does not occur in the bone apatite but rather in hydrocarbon concentrations within the bone cavities. Although the eU values of fossil bones from the Old Red sandstones may thus not accurately reflect uranium in the bone apatite, fossil bones are nevertheless, among the most uraniferous apatites. The value of 0.83 percent uranium (table 5) is the highest uranium content of which we are aware for any apatite substance (bones or mineral specimens).

Lacking the economic and geologic interest of the phosphorites, bones have not been extensively studied for uranium. However, certain well-established generalizations may be drawn from available information. Analyses presented by Hébert (1947), Oakley (1955a, b), and Jaffe and Sherwood (1951), all show fresh bone of marine or terrestrial organisms to be essentially nonuraniferous. In addition, comparisons of radioactivity of Cenozoic human and animal bones (Oakley, 1955a, b), reveal that uranium content increases with time, an indication of postburial uptake. As in the guanoderived phosphorites, uranium uptake in bones parallels fluorine uptake; apatite of all types is a favorable receptor for both of these elements.

The above facts, and the experimental extraction of uranium from solution by apatite (Moore, 1954) and by glycol-ashed ${ }^{4}$ modern bone (Neuman and others,

\footnotetext{
A procedure for removing tissue and organic matter.
}

1949), clearly demonstrate that the uranium of fossil bone is due entirely to secondary enrichment from ground water or marine sources. As Davidson and Atkin (1953) have pointed out, the most uraniferous fossil bones come from continental gravels of high permeability. In the highly quartzose and felspathic terrestrial deposits, a fossil bone may be the most, and possibly the only, favorable host for uranium (and fluorine). In such circumstances, ground water charged by uranium from regional sources may effect unusual concentrations of uranium in isolated bones or phosphorites nodules and cause an enrichment far greater than that of the enclosing rocks. Thus, Smith and Bradley (1952) report dinosaur bones from the Cloverly formation which contain from 0.085 to 0.135 percent of uranium, whereas the enclosing rocks contain only 0.001 to 0.005 percent of uranium.

Denson and Gill (1956) have shown that the highly uraniferous lignites of the Fort Union and Hells Creek formations in northwestern South Dakota and eastern Montana have derived their uranium from percolating ground waters which were (and still are) enriched by leaching of the overlying tuffs. Undoubtedly, the fossil bones from these formations have become uraniferous through the same agency. The titanothere bone from the Hells Creek formation (table 5) exemplifies this type of enrichment. Probably Miles City fossil W-3841 (table 5), from an unknown surface exposure in the same region, derived its unusual uranium content in the same manner.

Petrographic evidence of the mode of such postdepositional enrichment is shown by an autoradiograph of specimen $\mathrm{W}-3841$ (pl. 11, fig. $D$ ). The most uraniferous (the lightest) parts of the bone are the peripheral zones and the cavernous and highly permeable internal structures. In contrast to these areas, the intermediate dense areas are of relatively low grade. Obviously, uranium concentration bears no relation to the great difference in apatite concentration. In addition, it was determined by X-ray powder diffraction analysis of different portions of the specimen that the apatite is of the same type throughout, and further analyses on separated material showed that the carbon-rich fraction has less uranium than the mineral fraction. Evidently accessibility to solutions was the main control on the localization of the uranium.

Unlike the contrast between bones and enclosing rock in terrestrial deposits bones and other phosphatic fossils in unaltered marine phosphorites are generally similar in uranium content to the apatite pebbles and pellets from the same deposits. This supports the argument that the unusual postdepositional enrichment of continental fossils is attributable to special provenance 
rather than special mechanism. Analyses of 12 fossil manatee rib fragments and shark teeth from mines in the Bone Valley formation showed a range in uranium content of 0.004 to 0.016 percent (Jaffe and Sherwood, 1951). The $\mathrm{P}_{2} \mathrm{O}_{5}$ contents of the same specimens ranged from 36.1 to 37.5 percent, indicating that all were relatively pure carbonate-fluorapatite. The manatee and shark specimens represented species that ranged from Miocene through Pliocene and many of the Bone Valley fossils have been reworked from the Hawthorn formation. Nonbiogenic apatite of virtually identical composition and geologic history has essentially the same range of uranium content. The simple sand- and granule-size apatite pellets from the Hawthorn formation (primary) and the Bone Valley formation (reworked and possibly primary) are pure carbonatefluorapatite containing 36 to 38 percent $\mathrm{P}_{2} \mathrm{O}_{5}$. Their uranium content (table 5) ranges from 0.004 to 0.012 percent.

\section{MARINE ENRICHMENT AND REWORKING}

It has been shown that postdepositional alteration can cause large variation in the uranium contents of apatite deposits and that many of these variations can be ascribed directly to ground water leaching or enrichment. This does not, however, explain the apparently primary variation in unaltered materials. This problem has two aspects, illustrated by tables 12 and 19. Table 12 shows that similar materials from different deposits can differ significantly in uranium content. Thus, the Moroccan deposits, composed of primary apatite nodules of simple texture, have a much higher uranium to phosphate ratio than the comparable primary, simple nodules of the Hawthorn formation.

Table 19 demonstrates, in terms of the Bone Valley and Hawthorn formations, the extent to which the components of the same deposits may differ in uranium content.

The following facts are evident from table 19:

1. Pebbles, which are complex in texture, are richer as a class than pellets, which are simple in texture.

2. Pellets from the Bone Valley formation are richer as a class than those from the Hawthorn formation.

The texturally complex pebbles represent materials that have gone through two or more cycles of erosion and deposition. In addition, the nodules of the Bone Valley formation differ from those of the Hawthorn formation only by the fact that the former have been reworked from the latter. The differences in uranium content cannot be explained in terms of relative concentration, as it has been shown (Cathcart, 1956) that the coarse pebbles as a class contain less $\mathrm{P}_{2} \mathrm{O}_{5}$ than the finer
TABLE 19.-Uranium content of representative clastic apatite from the land pebble phosphate field, Florida

[Analyst, R. S. Clarke, Jr.]

\begin{tabular}{|c|c|c|c|}
\hline Sample & Formation & Locality & $\mathrm{U}$ (percent) \\
\hline \multicolumn{4}{|c|}{ Individual apatite pebbles } \\
\hline $\begin{array}{l}\text { B.L. }-1 . \\
\text { B.L. }-2 \text { - } \\
\text { B.L. }-3 . \\
\text { Ho-14_ } \\
\text { Ho-15_ } \\
\text { Ho-16. } \\
\text { Ho-17_ }\end{array}$ & 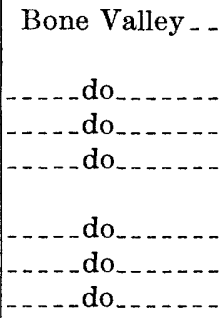 & $\begin{array}{l}\text { Bonny Lake mine, Ridge- } \\
\text { wood, Fla. } \\
\text { Homeland mine, Homeland, } \\
\text { Fla. } \\
\text { do do }\end{array}$ & $\begin{array}{l}0.011 \\
.018 \\
.016 \\
.032 \\
.022 \\
.015 \\
.021\end{array}$ \\
\hline \multicolumn{4}{|c|}{ Apatite pellets (composite samples) } \\
\hline $\begin{array}{l}\mathrm{Va}-1 \\
\mathrm{Va}-7 \\
\mathrm{Va}-10 \\
\mathrm{Ho}-12 \\
\mathrm{Ho}-13 \\
\mathrm{Ho}-14\end{array}$ & 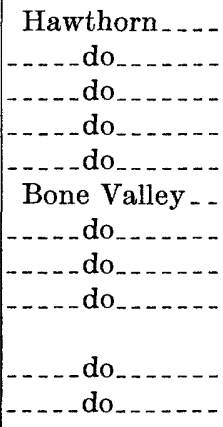 & $\begin{array}{l}\text { Sarasota, Fla } \\
\text { Venice, Fla } \\
\text { Land pebble field, Fla } \\
\text { Varn mine, Fort Meade, Fla } \\
\text { Homeland mine, Homeland, } \\
\text { Fla. } \\
\text { do do. }\end{array}$ & $\begin{array}{r}0.0059 \\
.0067 \\
.0045 \\
.0071 \\
.0075 \\
.008 \\
.011 \\
.0115 \\
.0127 \\
.0123 \\
.0089\end{array}$ \\
\hline
\end{tabular}

materials. This fact is explained by the complex nature of the pebbles which generally contain quartz and carbonate diluents.

The coarse pebbles of the Bone Valley formation are more abundant in the base of the deposits than higher in the section. They commonly have internal unphosphatized remnants of dolomite and calcite. In addition, they contain clastic quartz and primary phosphate pellets and other pebble fragments. Both the primary and the second-cycle laminations or textures within the pebbles are discordant to the boundaries.

All these features, coupled with field evidence of stratigraphic unconformity between the Bone Valley formation and the underlying Hawthorn, indicate a record of marine transgression with many pulses of reworking. It seems reasonable to suppose that the re-exposure to sea water sustained by the reworked Bone Valley material allowed additional uptake of uranium. Thus, the uranium content of the complex pebble components in the Bone Valley is enhanced by increments of uranium during successive cycles of reworking. The pellets in the Bone Valley, also reworked from the Hawthorn, correspondingly contain 
more uranium than the pellets in the Hawthorn. Within the Bone Valley, however, the pellets, as expected, contain less uranium than the pebbles as they evidently have not been "worked" as frequently. Thus they are more commonly found above the basal conglomeratic zone, and they lack the textural complexity of the pebbles.

The hypothesis of uranium enrichment during reworking can be tested by comparing the autoradiographs of a complex pebble and a pebble of first generation (pl. 11, figs. E. F). The complex pebble is not uniformly radioactive, in contrast to the prevailing uniformity of the simple pebble. Moreover, within the reworked pebble the most radioactive parts are the oldest or reincorporated materials. The strong peripheral enrichment shown by the fossil bone autoradiograph (pl.11, fig. D) shows the distribution of uranium that would be expected if the pebbles owed much of their uranium to ground-water enrichment.

The absence of such peripheral enrichment or of any gradational enrichment from the surface inward, regardless of texture, supports the conclusion that uranium was not introduced by ground water. The intensity of radioactivity varies with the textures created by reworking, providing proof of uranium emplacement during the marine reworking. Clearly in itself reworking served merely to expose the material to the marine source of uranium. Fortunately, however, reworked materials provide a demonstration that increased exposure to such a source results in increased uranium content.

The effect of total time of exposure to sea water may explain differences in uranium content of similar apaties from different marine deposits. Such discussion is perforce speculative as it is impossible to assess the chemical oceanographic factors controlling the uranium solubility or concentration. Nevertheless, it is possible to develop a reasonable explanation based on available geologic facts. For example, the pellets of the Florida and the Morocco deposits are chemically alike (table 3 ), yet the nodules from Morocco contain 2 to 3 times as much uranium as those from Florida. The analyes of Morocco deposits in table 12 represent phosphatic marls containing clastic apatite, clay, and minor chert. They are practically devoid of detrital quartz and the bulk of their particles are of fine sand size (table 8). In contrast, the Florida phosphates are poorly sorted conglomeratic sands and clays, and their pellets are commonly coarse sand to granules in size. The Florida phosphates were undoubtedly much more quickly deposited than the Moroccan phosphates and in view of the compositional similarity of the two, the difference in their uranium content may be largely a reflection of the difference in the length of exposure to sea water.

\section{CRYSTALLO-CHEMICAL NATURE OF URANIUM IN APATITE}

\section{GENERAL STATEMENT}

It seems clear that uranium in phosphate deposits cannot be accounted for by discrete uranium phases, by absorption, or by loosely adsorbed ions, radicals, or phases. This follows from several lines of evidence in the preceding sections:

1. Lack of uranium minerals.

2. Fluorescence of uraniferous apatite.

3. Lack of correlation of uranium content with any physical property such as size, magnetism, color; and inability to concentrate uranium by physical means.

4. Inability to selectivity leach uranium.

5. Lack of abnormal concentrations in specific petrographic types of apatite.

Moreover, nuclear emulsion studies of many phosphorite samples from the Bone Valley and Phosphoria formations have shown that the uranium atoms are intimately dispersed within apatite rather than locally segregated. Plate 13 is a photomicrograph showing the alpha track distribution obtained from an apatitecemented arkose from the Gas Hills area of Fremont County, Wyo. Concentrates of cement from this sandstone are found to contain tenths of one percent of uranium. The tracks shown in the photomicrograph are the recorded paths of alpha particles emitted during the distintegration of individual radioactive atoms. The intimate and homogeneous distribution of uranium that can be inferred from the lack of clustering or of a preferred pattern in the track distribution is typical of unaltered phosphorite. The uranium distribution has been illustrated with the Fremont County apatite because its high uranium content yields clearer results than are normally obtainable with lower grade materials, which need exposures of several months and frequently result in fogged emulsions. The Fremont, County apatite serves the additional advantage of demonstrating that even in highly uraniferous apatite random dispersion prevails rather than local concentration.

The evidence summarized above and the nuclear emulsion results indicate that uranium occurs as an integral part of the apatite structure. The evidence from the aluminum phosphate zone of the Bone Valley formation in which uranium and calcium contents are parallel (fig. 9), despite the fact that one is a mere trace and the other a major constituent, indicates that uranium substitutes for calcium in apatite. 


\section{SUBSTITUTION OF URANIUM FOR CAICIUM IN APATITE}

THEORETICAI CONSIDERATIONS

The substitution of uranium for calcium is crystallographically plauisible in terms of $\mathrm{U}^{+4}$ which has an ionic radius $(\mathrm{IR}=0.97 \mathrm{~A})$ virtually identical to that of calcium (IR $=0.99 \mathrm{~A})$. The problem of maintaining electrostatic neutrality in substituting a tetravalent for a divalent ion may be reasonably discounted in this case for two reasons. First, the content of uranium in apatite is far too slight to create any appreciable structural dislocation. Thus, a uranium content of 0.01 percent in apatite is equivalent to one atom of uranium for every 2362 unit cells $\left[\mathrm{Ca}_{10}\left(\mathrm{PO}_{4}\right)_{6} \mathrm{~F}_{2}\right]$ or to 1 atom of uranium for every 23,620 atoms of calcium! Second, the deficiency of positive charge created by other replacements common in apatite is orders of magnitude greater than would be required to compensate for the excess of positive charge caused by the replacement of calcium by uranium. For example, from 0.1 to 1.0 percent of sodium is common in apatite as a replacement for calcium, and fluorine plus hydroxyl are in excess in carbonate-fluorapatite to an extent of 0.5 to 1.0 percent.

\section{RELATION OF URANIUM TO PHOSPHORUS}

The suggestion has been made that uranium ions may substitute for phosphate tetrahedra or the phosphorous ion in apatite. Several arguments militate against this hypothesis:

1. The absorption of uranyl by apatite in the laboratory has been found to render phosphate nonexchangeable rather than to proceed by displacement of phosphate as it does of calcium (Neuman and others, 1949a, b).

2. The uranous ion (IR $=0.97 \mathrm{~A}$ ) is too large to substitute for phosphorus (IR $=0.35 \mathrm{~A}$ ) in $\mathrm{PO}_{4}$ tetrahedra, and it normally requires a much larger coordination with oxygen, as displayed by the eight-fold coordination of $U$ (IV) in $\mathrm{UO}_{2}$ (Wells, 1950).

3. In the uranium-enriched aluminum phosphate zone of the Bone Valley formation, the uranium is concentrated preferentially in the calcium and calcium-aluminum phosphates and relatively impoverished at the top of the zone (fig. 9) where only wavellite, the pure aluminum phosphate occurs. Although the wavellite occurs as an alteration product of apatite and crandallite (fig. 9), chemical analyses of pure wavellite reveal that very little uranium is re- tained by the wavellite in the course of its replacement of the pre-existing uraniferous minerals (Altschuler and others, 1956).

\section{OXIDATION STATE OF URANIUM IN APATITE CHEMTCAL PROBLEMS}

Is the uranium in apatite tetravalent? To answer this question and questions concerning the industrial recovery of uranium, a method was developed for the analysis of $U(I V)$ in apatite. The details of the method are treated in Clarke and Altschuler (1958); however, as the results are treated below, it is of interest to discuss some of the chemical problems involved in developing the method as they bear cogently on the geochemistry of uranium.

As the total quantity of uranium in most apatite is very small, the analyses of that portion of it which is tetravalent presents two problems. First, the sample must be dissolved under conditions that allow neither oxidation nor reduction of its uranium. Second, the minute traces of $U(I V)$ must be separated as a uranous cupferrate. The separation is easily accomplished by the use of titanium, which also forms an insoluble cupferrate, and hence can be used as a collector or coprecipitant of the traces of uranous cupferrate present. The initial problem of maintaining the original valence state of uranium in solution is more vexing, however, as it is aggravated by the presence in apatite of many elements which directly or catalytically influence the oxidation state of uranium. Iron (present in virtually all apatite) and cerium (present in most igneous apatites) can, depending on their states, oxidize or reduce uranium. In addition, air oxidation of uranous solution is catalytically augmented by ions of silicate, molybdenum, copper, and cobalt (Pannell, 1950 ), all of which may be present in apatite in trace quantities. Of all these, iron is the element of greatest concern owing to its ubiquitous occurrence and its quantity in phosphorite relative to uranium, as illustrated in table 20.

TABLE 20.-Iron and uranium content, in weight percent of representative apatites from the Bone Valley formation, Florida

[Analyst, R. 8. Clarke, Jr.]

\begin{tabular}{|c|c|c|c|c|c|}
\hline Sample & Location & Material & Fe & $\mathrm{Fe}$ (II) & U \\
\hline B.L. 3. & Bonny Lake mine........ & Pebbles... & 0.26 & 0.14 & 0.016 \\
\hline VA $5 \ldots$ & Varn mine .......... & Pebbles, nodules....... & .33 & .06 & .021 \\
\hline WA $10 \ldots$ & Watson mine.............. & Nodules..................... & .60 & .04 & .0078 \\
\hline P.V. 5 & Peace Valley mine....... & - do do & 1.00 & .06 & .006 \\
\hline
\end{tabular}


It is known from theoretical and experimental considerations that the iron and uranium couples can react in the following manner:

$$
2 \mathrm{Fe}(\mathrm{II})+\mathrm{U}(\mathrm{VI}) \rightleftharpoons 2 \mathrm{Fe}(\mathrm{III})+\mathrm{U}(\mathrm{IV})
$$

The extent to which this interaction takes place in nature would be governed greatly by the $\mathrm{pH}$ of the medium, the relative concentrations of the individual members of the couples, and the presence of other oxidents, reductants, and stabilizing compounds, capable of influencing the direction of the reaction. Of considerable interest is the determination by Baes (1954) that the reduction of $\mathrm{U}$ (VI) to $\mathrm{U}$ (IV) by $\mathrm{Fe}$ (II) is greatly enhanced in phosphoric acid solutions at room temperature. This production of $\mathrm{U}(\mathrm{IV})$ was augmented by increasing the phosphoric acid concentration and further promoted by the presence of fluoride ion (Baes, 1954), which forms stable complexes with both $\mathrm{Fe}$ (III) and U(IV). Schreyer (1954) has shown that uranium (IV) forms stable orthophosphate complexes in phosphoric acid solutions to an extent that limits air oxidation of $\mathrm{U}(\mathrm{IV})$.

Additional verification of the efficacy of the above reactions in acid solutions is obtained from experience in the industrial recovery of uranium as a byproduct of phosphoric acid in triple-superphosphate production. In this process, apatite is treated with sulfuric acid to produce phosphoric acid and gypsum. The final product, monocalcium phosphate is manufactured by treatment of additional apatite by the phosphoric acid. Uranium is extracted from the phosphoric acid phase of this process by use of alkyl pyro-phosphoric acids (Ellis, 1952). It has been found in the course of recovery studies that the uranium must be sequestered from the phosphoric acid as the tetravalent ion. To effect complete recovery, the acids are passed over steel filings or punchings prior to extraction.

Thus, in view of the ability of ferrous iron to reduce $\mathrm{U}(\mathrm{VI})$ to $\mathrm{U}(\mathrm{IV})$ and the readiness with which both U(IV) and $\mathrm{Fe}$ (III) form stable compounds with the fluoride and orthophosphate ions, one could produce U(IV) merely in the course of dissolving apatite in order to make the analysis!

Most of the above experimental information on the independent behavior and mutual interactions of uranium and iron in phosphoric acid systems was obtained at room temperature and at concentrations of phosphate relative to uranium and iron comparable to those prevailing in apatite and many natural solutions. The acidities in the laboratory studies, however, are so much greater than those prevailing in nature as possibly to invalidate the application of the results to the interpretation of uraniferous apatite. Moreover, as it is impossible to define all of the variables that have affected the primary state of uranium in apatite, or all of the factors which may have altered it after emplacement, it is still necessary to determine chemically whether apatite contains tetravalent uranium. Furthermore, a method for this determination is also valuable as a means of assessing the relative quantities of hexavalent and tetravalent uranium during various stages of the industrial recovery process.

In devising a method for the analysis of U(IV) in apatite it was necessary to depress the oxidation and reduction, respectively, of the tetravalent and hexavalent uranium inherently present in apatite, and to establish that the analytical recovery is both high and consistent. Lacking proof that U(IV) actually occurs in apatite, experiments were performed on solutions of natural apatites and uranium-free synthetic apatites to which known spikes of uranous and uranyl solutions were added. Table 21 is a representative summary of a number of these experiments.

TABLE 21. - The recovery, in weight percent, of uranium (IV) from 1.5 $M$ phosphoric acid solutions of natural and synthetic apatite

[Assembled from Clarke and Altschuler, 1958]

\begin{tabular}{|c|c|c|c|c|c|c|c|c|}
\hline \multirow{2}{*}{ 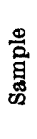 } & \multirow{2}{*}{ Material } & \multicolumn{2}{|c|}{$\begin{array}{c}\text { Initial } \\
\text { uranium }\end{array}$} & \multicolumn{2}{|c|}{$\begin{array}{l}\text { Uranium } \\
\text { added }\end{array}$} & \multicolumn{2}{|c|}{ Iron added } & \multirow{2}{*}{$\begin{array}{l}U(I V) \\
\text { deter- } \\
\text { mined }\end{array}$} \\
\hline & & Total & $\underset{\text { (IV) }}{\mathrm{U}}$ & $\underset{\text { (IV) }}{\mathbf{U}}$ & $\underset{(V I)}{\mathbf{U}}$ & $\begin{array}{l}\mathrm{Fe} \\
\text { (II) }\end{array}$ & $\begin{array}{c}\mathrm{Fe} \\
\text { (III) }\end{array}$ & \\
\hline 1 & Synthetic apatite...... & & & 0.050 & & & & 0.050 \\
\hline 2 & Synthetic apatite...... & & & .048 & $-\ldots$ & ....... & 0.100 & .050 \\
\hline 3 & Synthetic apatite....... & & $\ldots$ & ........ & 0.030 & 0.100 & $\ldots$ & .0025 \\
\hline 4 & $\begin{array}{l}\text { Apatite pebbles (B. } \\
\text { L.-3), Bonny Lake, }\end{array}$ & 0.016 & 0.012 & 050 & & & & 061 \\
\hline 5 & $\begin{array}{l}\text { Apatite pebbles (B. } \\
\text { L.-3), Bonny Lake, } \\
\text { Fla. }\end{array}$ & .016 & .013 & .048 & & & .100 & .060 \\
\hline 6 & $\begin{array}{l}\text { Apatite pebbles (B. } \\
\text { L.-3), Bonny Lake, } \\
\text { Fla. }\end{array}$ & .016 & .013 & .048 & & .100 & & .056 \\
\hline
\end{tabular}

It was determined (table 21, samples 1 and 4 ) that uranous uranium can be recovered from apatite. By additions of ferrous and ferric iron it was further determined that the reduction of uranyl (table 21, samples 3 and 6 ) and the oxidation of uranous uranium (table 21, samples 2 and 5) are both negligible. It should be noted that the percent of recovery of U(IV) in table 21 is virtually complete in all cases where $\mathrm{U}(\mathrm{IV})$ was added, and that it is less than 10 percent where only U(VI) was added (table 21 , sample 3 ).

A further demonstration that the $U(I V)$ values obtained are not merely governed by the experimental conditions is the production of more U(VI) and less $\mathrm{U}(\mathrm{IV})$ by treatment of the sample prior to analysis. 
Sample B.L. -3 was heated at $600^{\circ} \mathrm{C}$ for 4 hours in air. This treatment would be expected to oxidize at least part of the U(IV) present. A comparison of values obtained before and after treatment is given in table 22. Thus, by changing the inherent U(IV) in a predictable manner prior to analysis, and confirming the change by recovery, independent proof is had that the inherent $\mathrm{U}(\mathrm{IV})$ normally obtained is real, and not a function of the method of recovery.

TABLE 22.--Percentages of uranium and of $U(I V)$ in sample B.L. -3 before and after oxidative heating

[Analyst, R. S. Clarke, Jr.]

\begin{tabular}{|c|c|c|c|c|}
\hline Sample & Condition & Total & U (IV) & $\begin{array}{l}\text { Percent } \\
\text { reduced } \\
\text { U }\end{array}$ \\
\hline B.L.-3.- & Unheated & 0.016 & 0.013 & 81 \\
\hline B.L. -3 & Heated at $450^{\circ} \mathrm{C}, 4$ hours & .016 & .0085 & ${ }^{1} 53$ \\
\hline B.L. $-3 .-$ & Heated at $600^{\circ} \mathrm{C}, 4$ hours. & .020 & $\begin{array}{l}2.002 \\
3.002\end{array}$ & 12 \\
\hline
\end{tabular}

1 Total $U$ not determmed on heated sample. Percent reduced $U$ thus slightly high due to being uncorrected for weight loss on heating.

$2 \mathrm{H}_{3} \mathrm{PO}_{4}$ solution of sample.

$3 \mathrm{HCl}-\mathrm{NH}_{2} \mathrm{OH} . \mathrm{HCl}$ solution of sample.

Having established the validity of the method, the consistency of the results and the applicability of the method to a variety of materials was next studied. It was found that igneous fluorapatite, due to its much greater crystal size and its lack of carbonate, did not dissolve as readily as sedimentary apatite. As a result two different methods of solution have been used. Sedimentary apatite is dissolved in cold $1.5 M$ phosphoric acid and igneous apatite is dissolved in cold $1.2 \mathrm{M}$ hydrochloric acid containing 1.5 percent hydroxylamine hydrochloride. The U(IV) recovery from phosphoric acid is virtually complete, as demonstrated in table 21 . The U(IV) recovery from hydrochloric acid was established from spike experiments to average 79 percent. The range in percent recovery was from 67 to 87 percent; however, the standard deviation from the average of 79 percent was found to be only 5.4 percent (Clarke and Altschuler, 1958). Therefore, in analyses based on hydrochloric acid solutions a 20 percent correction will be applied to the value obtained, for a close approximation of the real value. It was found (Clarke and Altschuler, 1958) that materials with more than trace amounts of oxidizing or reducing elements, like cerium or iron, may not yield good results.

\section{U(IV) CONTENT OF SEDIMENTARY APATITES}

The U(IV) contents obtained on a variety of sedimentary and igneous apatites are given in tables 23 and 27.
The analyses in table 23 reveal a wide spread in the percentage of tetravalent uranium in apatite. The remainder, in all cases, is safely presumed to be hexavalent in view of the instability, and the absence in natural substances, of tervalent and pentavalent uranium (Garrels, 1955) and of the fact that monovalent and divalent uranium are competely unknown in natural solutions (McKelvey and others, 1955).

Several prevalent notions are open to serious question as a result of these analyses. It was heretofore generally assumed that the traces of uranium are of the same chemical nature in all apatite deposits; that, once fixed in apatite, uranium is not changed except insofar as the host mineral is altered; and that the uranium within any single specimen of apatite is entirely hexavalent or tetravalent. These assumptions must all be discarded.

Despite the variety displayed in table 23, the distribution of $U(I V)$ proportions is not haphazard and several important generalizations emerge if the data are regarded in the light of geologic occurrences.

\section{U(IV)/U PERCENTS REFLECT GEOLOGIC HISTORY}

Initially, to establish the validity of subsequent inference, it should be noted that materials with identical histories yield identical results. Thus, samples Ho-14 through Ho-17 in table 23 are composites of the same petrographic fraction from each of four successive beds in the Bone Valley formation. The particular strata are thin and therefore have the same general relation to the zone of aluminum phosphate alteration higher in the section. Although the total uranium content varies by as much as 100 percent among the samples, the percentage of $U(I V)$ is virtually identical throughout, within the limits of the fluorimetric analyses of uranium.

The reflection of geologic history in the $U(I V) / U$ percentages is further illustrated by several other groups of samples. Nodules from several localities in the Pacific Ocean off the coast of southern California, have sustained different degrees of submarine reworking and are of somewhat composite age, having also sustained accretion to differing extents since Miocene time. They are similar but not identical. Likewise their $\mathrm{U}(\mathrm{IV}) / \mathrm{U}$ percentages are similar but not identical. The apatite pellets from the Hawthorn formation were collected from two beaches along the central westFlorida coast. Both samples represent present-day marine reworking of Miocene apatite. Their $\mathrm{U}(\mathrm{IV}) / \mathrm{U}$ percentages are virtually identical. 
TABLE 23.-Total and tetravalent uranium content of sedimentary apatites

[Analyst, R. 8. Clarke, Jr.]

\begin{tabular}{|c|c|c|c|c|}
\hline Sample & Material & $\begin{array}{l}\text { Total U } \\
\text { (percent) }\end{array}$ & $\underset{\text { (percent) }}{\mathrm{U}(\mathrm{IV})}$ & $\frac{U(\mathrm{IV})}{\mathrm{U}}$ \\
\hline \multicolumn{5}{|c|}{ Bone Valley formation (Pliocene) } \\
\hline B.L.-1.. & Black pebble & 0.0011 & 0.010 & 91 \\
\hline B.L.-2.. & Dark pebble....... & .0089 & .0056 & 63 \\
\hline B.L. $-3 \ldots$ & Fine pebble composite.... & .016 & .013 & 81 \\
\hline Ho-14.... & 4-8 mm pebble composite............ & .032 & .016 & 50 \\
\hline Ho-15. & -....do................ & .022 & .011 & 50 \\
\hline Ho-16.... & do-1 & .015 & .007 & 42 \\
\hline Ho-17... & ..................... & .021 & .010 & 48 \\
\hline Va-7... & Apatite pellets. & .011 & .005 & 45 \\
\hline Va-7a... & ...................... & .009 & .006 & 67 \\
\hline WA-10 & do & .0075 & .003 & 40 \\
\hline PV-5... & do & .007 & .003 & 43 \\
\hline
\end{tabular}

Hawthorn formation (Miocene, recently reworked on Gulf Coast beaches)

\begin{tabular}{|c|c|c|c|c|}
\hline GP-1 & Apatite pellets. & $\begin{array}{r}0.0067 \\
.0059\end{array}$ & $\begin{array}{r}0.0039 \\
.0037\end{array}$ & $\begin{array}{l}58 \\
63\end{array}$ \\
\hline \multicolumn{5}{|c|}{ Tennessee phosphates, Bigby formation (Ordovician) } \\
\hline Ak-2 & $\begin{array}{l}\text { Limestone, phosphatic............ } \\
\text { Brown-rock phosphate (Cenozoic } \\
\text { weathering). }\end{array}$ & $\begin{array}{r}0.00004 \\
.00074\end{array}$ & $\begin{array}{r}0.00001 \\
.00002\end{array}$ & $\begin{array}{r}25 \\
3\end{array}$ \\
\hline
\end{tabular}

\begin{tabular}{|c|c|c|c|c|}
\hline \multicolumn{5}{|c|}{ Moroccan phosphates (Senonian) } \\
\hline $\begin{array}{l}\text { Mor-3 } \\
\text { Mor-5...... } \\
\text { Mor-11 }\end{array}$ & A daily production average & $\begin{array}{r}0.012 \\
.012 \\
.008\end{array}$ & $\begin{array}{r}0.0018 \\
.0015 \\
.0006\end{array}$ & $\begin{array}{r}15 \\
13 \\
8\end{array}$ \\
\hline \multicolumn{5}{|c|}{ Phosphoria formation (Permian) } \\
\hline $\begin{array}{l}\text { Conda-300. } \\
\text { RAH-185. }\end{array}$ & Apatite pellets. & $\begin{array}{c}0.0063 \\
.017\end{array}$ & $\begin{array}{c}0.0015 \\
.003\end{array}$ & $\begin{array}{l}24 \\
18\end{array}$ \\
\hline
\end{tabular}

\begin{tabular}{|c|c|c|c|c|}
\hline \multicolumn{5}{|c|}{ Pacific Ocean, southern California (post-Miocene) } \\
\hline 69. & Phosphate nodules.. & 0.0089 & 0.0061 & \\
\hline 106. & .....do do & .0068 & .0040 & \\
\hline 127. & -.....do_.............. & .0041 & .0028 & 68 \\
\hline 158. & .....do...... & .0081 & .0050 & 62 \\
\hline 162. & $\mid \ldots . .$. do........ & .0125 & .0093 & 74 \\
\hline $183 \ldots$ & |...................... & .0051 & .0028 & 56 \\
\hline
\end{tabular}

Foseil bone

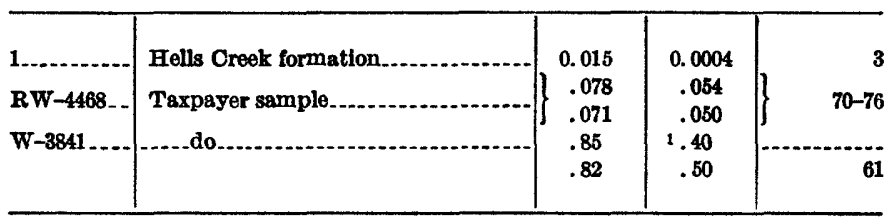

Phosphatic arkose

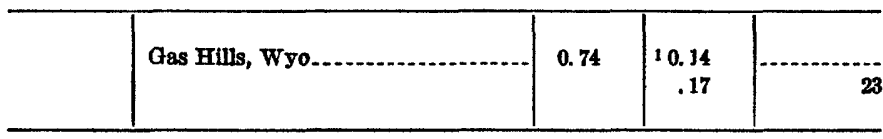

1 Determination from HCl solution; uncorrected for 20 percent defleiency in recovery.
PRIMARY MARINE URANIUM IN YOUNG PHOSPHORITES IS MAINLY U(IV)

In marine materials that have not been postdepositionally oxidized and that are of relatively young age, more than half of the uranium is tetravalent. The nodules from the Pacific serve as an example as they have been interpreted by Dietz, Emery, and Shepard (1942) to have been submerged since their formation in post-Miocene time. Samples B.L.-1, B.L.-2, and B.L. -3 (table 23), in which 63 to 91 percent of the uranium is tetravalent, were collected from clayey, impermeable strata in the basal conglomerate zone of the Bone Valley formation. Sample B.L.-1 has minute pyrite crystals and petroliferous organic matter dispersed throughout; however, the clay in which it rested was devoid of organic matter and pyrite. The pebble thus reflects the reducing conditions of its time and environment of formation and has not been postdepositionally weathered. Its content of U(IV), 91 percent of the total, is the highest we have found. Samples B.L. -2 and B.L. -3 are from higher strata, contain less organic matter, are lighter colored than B.L.-1, and have no pyrite. Less of their uranium is tetravalent.

\section{SUBAERIAI WEATHERING ALTERS U(IV) TO U(VI) IN MAAINE PHOSPHORITE}

Material that is obviously weathered contains proportionally less U(IV) than comparable or equivalent unweathered material. This may be illustrated by comparing the $U(I V) / U$ percentage obtained from the slightly phosphatic limestone of the Bigby formation with the much lower value obtained from the equivalent "brown-rock" phosphates derived from the Bigby by subaerial residual concentration. See table 23 and fig. 12 for relations of the samples.) A second illustration is obtained by comparing samples Ho-14 through Ho-17 with samples B.L.-1, B.L.-2, and B.L.-3. The two groups were collected from different mines (Homeland and Bonny Lake) and from different parts of the stratigraphic column and, hence, are not precisely equivalent. They are comparable, however, in their common origin, in their textural complexity, and in their overall composition. The Homeland samples were collected from an oxidized zone in the middle of the Bone Valley formation. Their associated clays are mottled and limonite stained, and the pebbles constituting the samples are light colored, and somewhat friable in contrast to the dark pebbles from the green, clayey, conglomerate at the base of the Bonny Lake mine. The appreciably lower U(IV) percentages in the Homeland materials demonstrate that some uranium may be oxidized in place in the host apatite. The enormous internal porosity of most phosphorite 
(Hendricks and Hill, 1950; Jacob and Hill, 1953) would greatly facilitate such oxidation, which, in fact, is visible in the form of limonite impregnations and micro-concretions dispersed throughout the apatite pebbles.

\section{POSSIBLE RELATION OF U(VI) CONTENT to RADIOACTIVITY AND AGE}

It may be that the $\mathrm{U}(\mathrm{IV}) / \mathrm{U}$ percentages in marine phosphorites are a function of radioactive disintegration and thus, indirectly, of age. This hypothesis presupposes that all, or most, of their uranium is initially $\mathrm{U}(\mathrm{IV})$, a suggestion favored strongly by the analyses of samples from the Bonny Lake mine and of the Pacific Ocean nodules. The thesis further demands that the $\mathrm{U}(\mathrm{VI})$ present is produced by auto-oxidation, or by some secondary effect whose onset is governed, both as to rate and intensity, by the progress of radioactive decay. If the $U$ (VI) content of apatite is related to age, rather than an independent result of oxidative weathering, it should be possible to demonstrate a progressive increase in $U(V I)$ content in a series of progressively older apatites. Such tests may soon be practicable for igneous apatites but their application to phosphorites is unfortunately prevented at present by the difficulty of obtaining materials assuredly free of oxidation from normal weathering. In addition to the difficulty of obtaining such materials, the few criteria at our command for establishing such freedom from oxidative weathering may be relatively insensitive. Such criteria are the presence of syngenetic glauconite, pyrite, and organic matter, or the presence of reduced ions in the apatite. Rarely, it may be possible to develop preclusive geologic evidence, such as a history of continual protective burial.

In exploring the possible relations of $U$ (VI) content to age in phosphorites, only three groups of samples may be compared with a modicum of assurance that they have not been weathered. They are (table 23) the Pliocene Bonny Lake pebbles, which contain pyrite and organic matter and were found in green clay beds; the Quaternary Pacific Ocean nodules, which have remained submerged since their formation; and possibly the pellets from the Permian Phosphoria formation, as these contain minor amounts of organic matter. It may be significant that the two Phosphoria samples show considerably lower $\mathrm{U}(\mathrm{IV}) / \mathrm{U}$ percentages than the other two groups, and that the two latter groups are moderately close in value. However, the extreme view that all of the uranium in apatite is initially U(IV) is not supported by the data. Although, in some samples (as in the Bonny Lake pebbles), favorable reducing conditions may cause substantially all the uranium in apatite to be taken up as U(IV), the existence of significant amounts of U(VI) in the young and recently dredged Pacific Ocean nodules suggests that the initial $U($ IV) $/ U(V I)$ ratio in apatite is influenced by the oxidation conditions in the marine environment. It is also possible however that submarine, postdepositional oxidation can lower the initial U(IV)/U(VI) ratio.

\section{SECONDARY SOURCES OF U(VI) IN PHOSPHORITE}

Only three analyses for U(IV) have been made on fossil bone; however, the spread in relative proportions of $U(I V)$ and $U(V I)$ (table 23) is indicative of the diversity that might be expected in view of the conceivable variations in the composition of the transporting ground water from which the uranium is emplaced, in the environment of deposition, and in the state of degradation of the organic matter that may be associated with the bones.

Although it is true that apatite readily abstracts U(IV) from solution, in a strongly oxidizing environment the mere presence of apatite is not necessarily effective in producing or even retaining U(IV). To the contrary, it was found that samples of Morocco apatite pellets and fossil bone that are richly encrusted by hematite have the capacity to oxidize uranous ions in phosphoric acid solutions, as the experiment in table 24 demonstrates. Iron free synthetic and natural apatite used as "controls" do not cause such oxidation.

\begin{tabular}{l} 
TABLE 24.-Experiment showing reduction of $\mathrm{U}(\mathrm{IV})$ by phosphoric \\
acid solutions of hematite-rich apatite samples \\
[Analyses in weight percent. Analyst, R. S. Clarke, Jr.] \\
\hline \\
Material
\end{tabular}

The data given in table 24 show that the complexing capacities of phosphate and fluoride ions for $\mathrm{Fe}$ (III) and $U(I V)$ respectively are not adequate to prevent the oxidation of $U(I V)$ in the presence of excess ferric iron. As this is true in solutions of freely mobile ions, it indicates that slowly dissolving apatite in the environment of such reactions would not prevent the oxidation of $\mathrm{U}(\mathrm{IV})$ by excess ferric iron. They also show that the very low values for U(IV) in samples Mor-3, 5, and 11 and Hell Creek 1 (table 23) may be due to oxidation effects during analysis, although it is to be expected that they would be low inherently. In 
any case the method is not trustworthy for materials with more than trace quantities of oxidizing impurities. It is clear from the above experiment, however, that high $\mathrm{U}$ (VI)/U percentages may be anticipated where uranium is emplaced primarily from ground water.

The phosphatic arkose sandstone from the Gas Hills region of Fremont County, Wyo., is a striking illustration of secondary uranium fixation by apatite. X-ray powder diffraction analyses show the material to be a carbonate-fluorapatite. Deposits of this material occur as cements scattered through the arkosic sandstones and conglomerates of the upper part of the Wind River formation..$^{5}$ Associated with them are "paints" of autunite and other secondary uranyl minerals; however, the sample used was shown by nuclear emulsion study and inspection under ultra-violet light to be free of uranium minerals. The apatite cement is attributed to secondary phosphatization, and the uranium is attributed mainly to secondary emplacement in the porous cement (R. G. Coleman, oral communication, 1956). This interpretation is supported by the occurrence of the uranyl phosphate and vanadate minerals throughout the region.

The alpha-track film of the specimen (pl. 13) reveals intimate and homogeneous dispersion of uranium throughout the cement, and a virtual absence of any uranium atom concentrations. It cannot be determined whether much or most of the uranium was originally fixed as U(IV) and subsequently oxidized or whether the U(VI) now present was emplaced substantially as uranyl. The local abundance of uranyl minerals and of limonite films in rocks other than phosphorite indicates that oxidizing solutions have permeated the area and have introduced uranium as uranyl.

The material emphasizes that U(VI) like U(IV) can be thoroughly dispersed in apatite and may be emplaced in a manner analogous to that demonstrated by Neuman and his coworkers $(1948,1949 a, b)$. They have shown that glycol-ashed bone will fix appreciable quantities of uranyl ion by exchange with surface calcium. This reaction was found to be surface limited (Neuman and others, 1949b) and involved the displacing of 2 moles of calcium for every mole of $\left(\mathrm{UO}_{2}\right)^{+2}$ taken from solution and the rendering of 2 moles of phosphate nonexchangeable. They suggest the formation of a compound analogous to uranyl pyrophosphate to explain these results.

\footnotetext{
- All information on occurrence has been obtained from R. G. Coleman, who kindly supplied the specimen, the second most uraniferous known to us.
}

Regarding the form in which uranyl complexes with apatite, several types of compounds should be considered. Uranyl pyrophosphates, or uranyl orthophosphates of the torbernite type could both be stable within the range of conditions presumable (oxidative, weakly alkaline to weakly acid). In addition, complexes of the type $\mathrm{UO}_{2} \mathrm{HPO}_{4}$ could presumably form by surface reaction with apatite; F. S. Grimaldi (oral communication, 1955 ) verifies that $\mathrm{UO}_{2} \mathrm{HPO}_{4}$ could be stable under such conditions. We believe that uranyl orthophosphate compounds are more probably the form in which primary U(VI) would occur in phosphorites. These would not require the polymerization entailed in pyrophosphate formation and would avoid the anomalous exchange of 2 divalent calciums for 1 divalent uranyl group. It is quite possible that an appreciable part of the U(VI) present in unweathered phosphorites is chemisorbed on the surfaces of growing apatite crystallites and, upon the complete development of the apatite nodules, the U(VI) appears to be intimately and randomly dispersed throughout the apatite. Sheldon (written communication, 1957) also favors the chemisorption of some hexavalent uranium in the rocks of the Phosphoria formation.

\section{RELATIVE STRUCTURAL FAVORABILITY OF U(IV) AND U(VI) IN APATITE}

The above mechanisms have one characteristic in common. Their surface-limited nature is virtually predictable in view of the asymmetry and large size of the uranyl anion $(3.4 \times 1.4 \mathrm{~A}$, Connick and Hugus, 1952) relative to the calcium ion $(\mathrm{IR}=0.99 \mathrm{~A})$. Thus, although the reactions so clearly documented by Neuman and his colleagues involve ion exchange, the results obtained indicate extensive structural rearrangement. It is therefore difficult to visualize any intra-crystalline solid solution by such a mechanism, first, because of the structural dislocation involved in formation of pyrophosphate and displacement of two calcium for one uranyl ion, and second, because the large uranyl anion could not migrate to any extent through the apatite structure. The channels within the hexagonal network of the fluorapatite structure, being barely wide enough to accept the fluoride ion (IR $=1.36 \mathrm{~A}$, Green, 1953), could not accommodate the uranyl anion. Sixty percent of the calcium ions in apatite line the vertical channels and would thus be inaccessible to postdepositional substitution by uranyl. On the other hand, the $\mathrm{U}(\mathrm{IV})$ ion could fit easily, and migrate a short distance within the channels, which are not as fully occupied 
as the walls and hence permit greater mobility to migrating ions. That such migration occurs is fully substantiated in the replacement of $(\mathrm{OH})$ by $\mathrm{F}$ that takes place in fossilization.

Structural considerations thus dictate that much more calcium is accessible for replacement by $U(I V)$ than by $U(V I)$. Furthermore, the U(IV) substitution does not involve any structural dislocation and the positive charge excess that would result is easily compensated by other known replacements of greater magnitude. It is not unusual, therefore, that samples as uraniferous as RW-4468 and W-3841 (table 23) should have as much as 70 and 61 percent respectively of their uranium in tetravalent form, despite the fact that ground water may be presumed to carry mainly uranyl ions.

\section{TEST OF URANIUM AND FLUORINE INTER- DEPENDENCE IN APATITE}

There are several compelling reasons for detailed examination of the relations between excess fluorine and uranium in marine apatite, as follows:

1. Excess fluorine is characteristic of marine sedimentary apatite, in contrast to normal igneous fluorapatite.

2. Marine apatite is characteristically more uraniferous than igneous apatite.

3. $\mathrm{UF}_{4}$ could be stable under the $\mathrm{pH}$ and $\mathrm{Eh}$ conditions of formation, and of subaerial preservation, of marine phosphorite. Although the formation of independent fluoride minerals is conceivable only under conditions of much greater salinity than those characterizing marine apatite formation (Kazakov, 1937), the possibility of a complex similar to $\mathrm{UF}_{4}$, as an integral part of apatite, is strongly suggested by the following:

A. The calcium ions lining the channels in the apatite structure are located in the same horizontal plane as the adjacent fluorine ions.

B. These channel calciums are coordinated to fluorine and oxygen (fig. 3 ), and as the excess fluorine could reasonably replace oxygen, or lodge within the channels in the apatite structure, the existence of $\mathrm{UF}_{4}$ in apatite may be reasonably postulated, particularly as $\mathrm{U}^{+4}$ may be considered to replace calcium.

4. The postdepositional uptake of fluorine and uranium by various forms of sedimentary apatite and bone involve separate replacements; however, their concomitant operation may mask, or be augmented by, their mutual complexing ability.

A general correlation between total fluorine and total uranium was demonstrated in studies of seven Pennsylvanian phosphatic shales of Kansas by Runnels and others (1953). In all likelihood this reflects only the fact that uranium content varies directly as apatite content in unaltered rocks of similar composition in which apatite is the only, or major, uranium host. Similar relationship could be expected in a group of phosphatic limestones and has been demonstrated for Mona Island rocks (fig. 3) and in some suites of rock from the Phosphoria formation (table 9).

The possible genetic relation between excess fluorine and $U(I V)$ is marine apatite should be tested in two ways. On the assumption that all of the uranium was originally fixed as $U(I V)$, excess fluorine should be compared with total uranium. Figure 13 is a scatter diagram on which total uranium is plotted against excess fluorine, ${ }^{6}$ as computed from a random selection of 50 of the analyses given by Thompson $(1953,1954)$ for Phosphoria samples from Trail Canyon, Utah; Coal Canyon, Wyo.; and Reservoir Mountain, Idaho. It can be seen that total uranium is independent of excess fluorine in rocks of the Phosphoria.

Assuming that only the U(IV) demonstrably present in apatite was emplaced as such, a comparison was made (fig. 14 of the few data available (table 25)) .

The wide scatter of the points in figure 14 indicates that $U(I V)$ and excess fluorine are independent of one another in marine phosphorite. The data are admittedly few ; however, the well-defined trends that can be demonstrated to exist among total fluorine, $\mathrm{P}_{2} \mathrm{O}_{5}$, and uranium, for groups of samples no larger than this (fig. 5, and Runnels and others, 1953) exemplify the extent of mutual dependence that could be expected between $F$ and $U(I V)$ if uranium occurred in apatite as a result of $\mathrm{UF}_{4}$ formation.

\section{EFFECTS OF REWORKING ON U(IV) CONTENT OF APATITE}

The demonstrated secondary enrichment of uranium in apatite during the course of marine reworking allows the establishment of controls for studying the nature of the uranium extracted from the ocean source. If the uranium additions incident to reworking are mainly $\mathrm{U}(\mathrm{IV})$, the $\mathrm{U}(\mathrm{IV}) / \mathrm{U}$ percentages should be higher in the reworked materials of a deposit. Samples were taken in the phosphatic terrace gravels in the vicinity of Charleston, South Carolina, for tests of this thesis. The phosphatic fraction of the samples consisted of sand-size pellets and detrital bone apatite, mainly water-worn shark tooth fragments, plus rounded granules and pebbles of bone and phosporite. In addition, the samples contained quartz and shell fragments. The coarser material was found to be texturally more complex, indicating more reworking. Accordingly, each

\footnotetext{
- Based on 3.8 percent of fluorine in pure fluorapatite and 38 percent $\mathrm{P}_{2} \mathrm{O}_{5}$ in carbonate-fluorapatite. Therefore excess fluorine is amount in excess of theoretical $\mathrm{F} / \mathrm{P}_{2} \mathrm{O}_{5}$ weight ratio of $1 / 10$.
} 


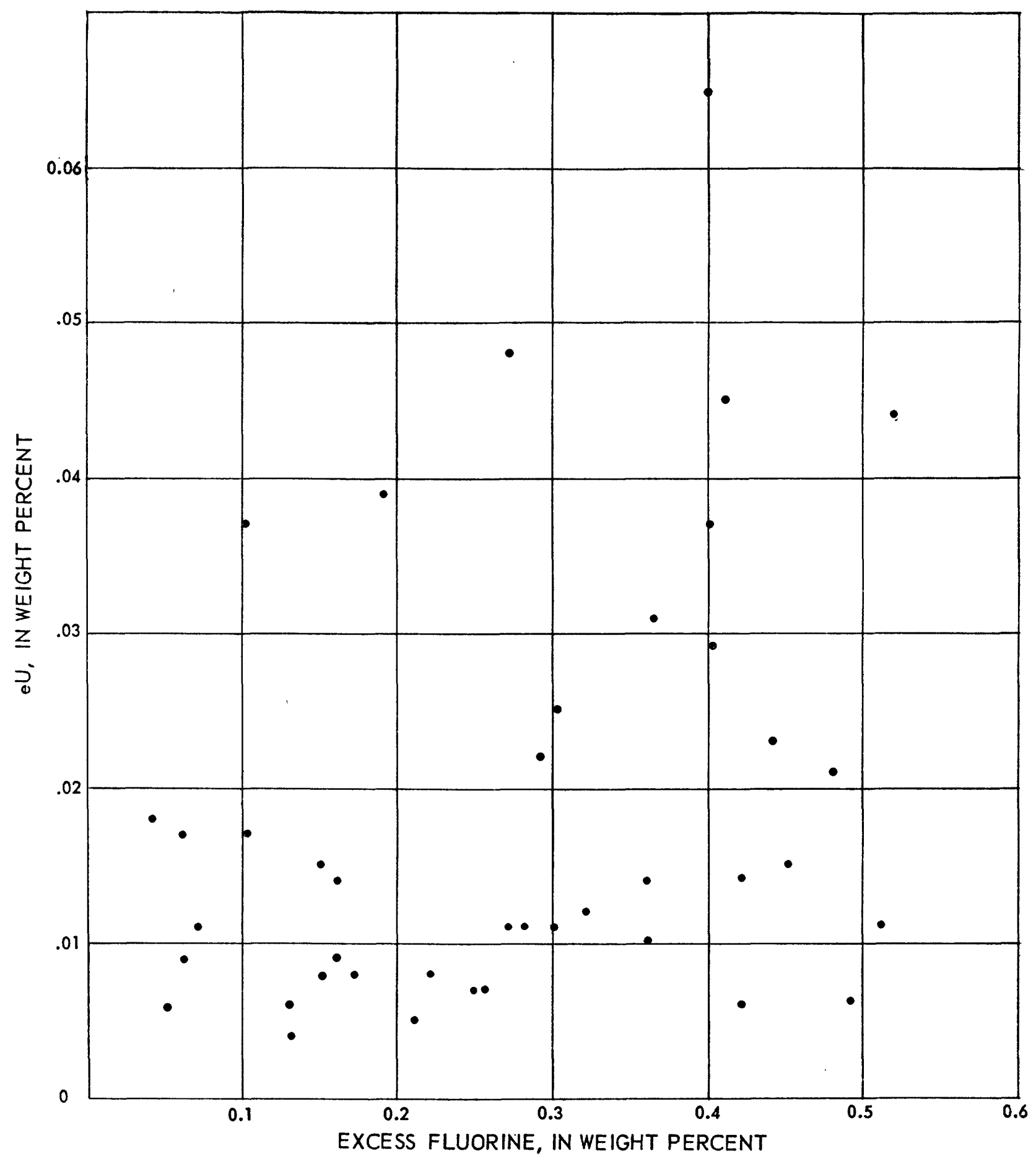

Fiauri 13.-Uranium vs excess fluorine in Phosphoria formation (data recomputed from Thompson, 1953). 


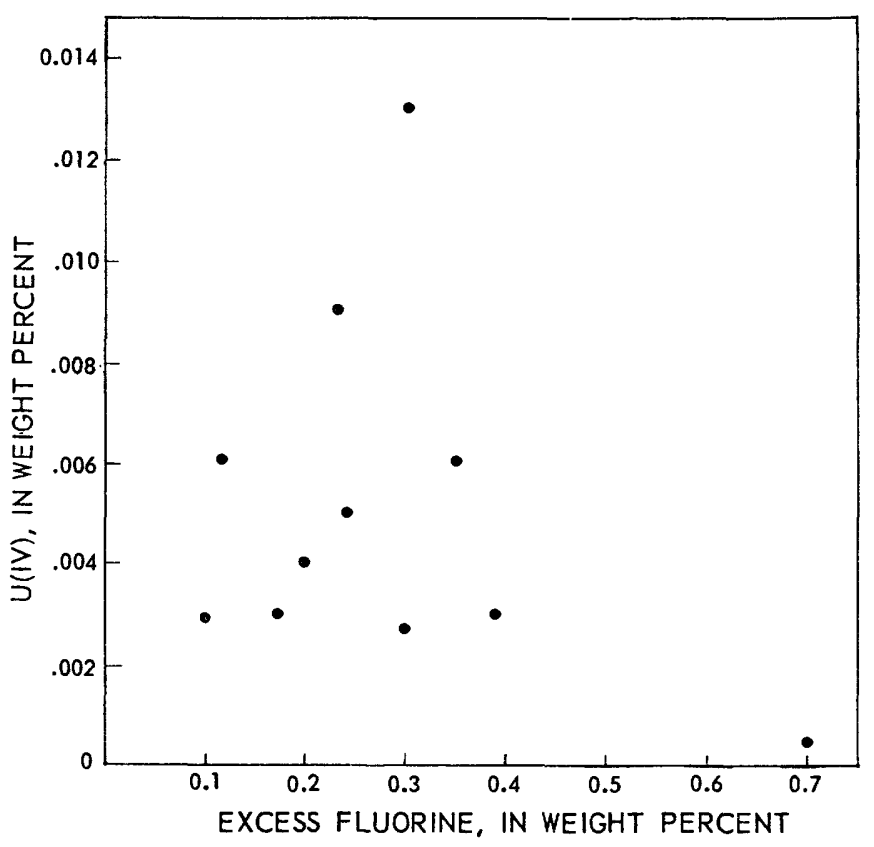

FIGURE 14.-U(IV) vs excess fluorine in various phosphates.

TABLE 25.-Data on excess fuorine and U(IV) in miscellaneous apatite and phosphorite

[All analyses from U. S. Geological Survey Laboratory; F and $\mathrm{P}_{2} \mathrm{O}_{5}$ on Pacific nodules are given in Dietz, Emery, and Shepard (1942)]

\begin{tabular}{|c|c|c|c|c|c|c|c|}
\hline \multirow{2}{*}{ Sample } & \multirow{2}{*}{ Material } & \multirow{2}{*}{ Locality } & \multicolumn{4}{|c|}{ Percent } & \multirow{2}{*}{ Remarks } \\
\hline & & & $F$ & $\mathrm{P}_{2} \mathrm{O}_{5}$ & $\begin{array}{c}\text { Ex- } \\
\text { cess } \\
F\end{array}$ & $\mathrm{U}(\mathrm{IV})$ & \\
\hline $\mathrm{PV}-5$ & Apatite & Peace Valley & 3.8 & 34.5 & 0.3 & 0.0027 & Bone Valley forma- \\
\hline Wa-10 & _._do ....... & $\begin{array}{l}\text { Watson mine, } \\
\text { Fla. }\end{array}$ & 3.8 & 36.6 & .1 & .0029 & Do. \\
\hline BL-3.- & ... do & $\begin{array}{c}\text { Bonny Lake } \\
\text { mine, Fla. }\end{array}$ & 3.8 & 34.9 & .3 & .013 & Do. \\
\hline Mor-11 & -._do_.... & $\begin{array}{r}\text { Khouribga, } \\
\text { Morocco. }\end{array}$ & 4.05 & 33.4 & .7 & .005 & $\begin{array}{l}\text { A verage sample, } \\
\text { daily production. }\end{array}$ \\
\hline $69 \ldots$ & $\begin{array}{l}\text { Phos- } \\
\text { phate } \\
\text { nodule. }\end{array}$ & $\begin{array}{l}\text { Pacific } \\
\text { Ocean. }\end{array}$ & 3.31 & 29.56 & .35 & .006 & $\begin{array}{l}\text { Sample members, } \\
\text { these of Dietz and } \\
\text { others (1942). }\end{array}$ \\
\hline 106 & ._. do _... & .... do & 3. 12 & 29.19 & .20 & .004 & Do. \\
\hline 127 & . do . & .... do & 3.07 & 28.96 & .17 & .003 & Do. \\
\hline $158 \ldots$ & -._do & _....do_._. & 3.15 & 29.09 & .24 & .005 & Do. \\
\hline 162 & $\ldots$ do & . & 2.47 & 22.43 & .23 & .009 & Do. \\
\hline 183 & . $\mathrm{do}$ & . & 3. 36 & 29.66 & .39 & .003 & Do. \\
\hline
\end{tabular}

sample was split into two fractions on the basis of size and analyzed for $\mathrm{P}_{2} \mathrm{O}_{5}, \mathrm{U}$, and $\mathrm{U}(\mathrm{IV})$. The results are given in table 26.

The samples from each locality were fractionated by screening and the obvious shell fragments were handpicked from the coarse fraction in each case. It was not practical to remove shell fragments from the fine fraction. Table 26 shows that the coarse fraction contains less $\mathrm{P}_{2} \mathrm{O}_{5}$ at all 4 localities and more uranium in 3 of the 4. The lower $\mathrm{P}_{2} \mathrm{O}_{5}$ reflects the greater textural
TABLE 26. - Relative contents of $\mathrm{U}, \mathrm{U}(\mathrm{IV})$, and $\mathrm{P}_{2} \mathrm{O}_{5}$ in phosphatic terrace gravel in the vicinity of Charleston, S. C.

[Analyst, R. S. Clarks, Jr.]

\begin{tabular}{|c|c|c|c|c|c|c|}
\hline Sample & Miaterial & $\underset{\text { (per- }}{U}$ & $\begin{array}{l}\mathrm{P}_{2} \mathrm{O}_{5} \\
\text { (per- } \\
\text { cent) }\end{array}$ & $\frac{\mathrm{UX} 1000}{\mathrm{P}_{2} \mathrm{O}_{5}}$ & $\begin{array}{l}\text { U(IV) } \\
\text { (per- } \\
\text { cent) }\end{array}$ & 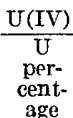 \\
\hline
\end{tabular}

Accabee Flats, Ashley River, Charleston, S. C.

\begin{tabular}{l|l|r|r|r|r|r}
\hline & & & & & \\
Acc-1.... & +2 mm pebble & & & & \\
Acc-1_........... & 0.020 & 28.4 & 0.70 & 0.016 & 80 \\
Acc-2.... & Medium to fine sand.....-. & .020 & 31.7 & .63 & .013 & 65 \\
& & .018 & 30.2 & .60 & .013 & 72 \\
\hline
\end{tabular}

Micah Jenkins Nursery, Johns Island, S. C.

\begin{tabular}{l|l|r|r|r|r|r}
\hline Micah-1_- & +2 mm pebble_........... & .027 & 27.6 & .98 & 0.021 & 78 \\
Micah-1_- & Medium to fine sand & .015 & 31.2 & .48 & .011 & 73 \\
\hline
\end{tabular}

Ninemile Station, S. C.

\begin{tabular}{|c|c|c|c|c|c|c|}
\hline Nime -1 & +4 mm pebble.... & .037 & 27.5 & 1.35 & 0.025 & 68 \\
\hline Nine-2... & Medium to fine sand & .021 & 31.4 & .67 & .010 & 48 \\
\hline
\end{tabular}

Lambs, S. C.

\begin{tabular}{|c|c|c|c|c|c|c|}
\hline Lamb-1_. & +2 mm pebble... & .015 & 28.6 & .52 & 0.0097 & 65 \\
\hline Lamb-1.. & Medium to fine sand & .025 & 31.5 & .79 & .012 & 48 \\
\hline
\end{tabular}

complexity and greater percentage of inclusions resulting from reworking. The generally higher uranium content reflects the enhancement of uranium during reworking. The fact that in all samples the $U(I V) / U$ percentages are significantly higher in the reworked materials proves that the additional increments of uranium are largely tetravalent.

\section{SUMMARY OF EVIDENCE BEARING ON THE PRIMARY STATE OF URANIUM IN IMARINE PHOSPHORITES}

The theoretically plausible occurrence of U(IV) in apatite has been confirmed in these investigations by demonstrating that $U(I V)$ actually does occur and indeed is the predominant ion species of uranium in some phosphorites. In addition, considerations of the crystal chemistry of apatite lead to the conclusion that structural emplacement of $\left(\mathrm{UO}_{2}\right)^{+2}$ is most probably surface-limited and, therefore, not as favorable as structural emplacement of the $\mathrm{U}^{+4}$ ion. Nevertheless, the fine-grained nature of most phosphorite results in an exceptionally large inherent surface area (Hendricks and Hill, 1950; Jacob and Hill, 1953) which can accommodate all of the uranium in typical phosphorite as chemically adsorbed uranyl, as has been pointed out by Hendricks and Hill (1950) and Sheldon (written communication, 1957). It is thus important to examine the significance of the wide range in the $U(I V) / U$ 
percentages of marine phosphorites (table 23). Do the data accurately represent the primary state of the uranium deposited in apatite?

In answering the above question we must consider laboratory and field evidence bearing on the relative stabilities of $\mathrm{U}^{+4}$ and $\mathrm{UO}_{2}+2$ under subaerial exposure. Garrels has shown (oral communication, 1955, and McKelvey and others, 1955) that the reduction of uranyl to uranous uranium can be effective at $25^{\circ} \mathrm{C}$ and a pH of 4 or higher, for small amounts of uranyl and a wide range of ferrous iron concentration. The previously cited stabilizing effect of phosphate and fluoride on this reaction can appreciably increase the production of $U(I V)$. It is also probable that $U(I V)$ may be produced from $\mathrm{U}(\mathrm{VI})$ by the oxidation of organic matter or $\mathrm{H}_{2} \mathrm{~S}$. Both Gruner (1952) and Miller and Kerr (1954) have successfully precipitated $\mathrm{UO}_{2}$ by such reactions at low temperature and pressure. The presence of apatite in the milieu of such reactions would fix the U(IV) so produced, by ion exchange with calcium. Beyond this, by its extracting action, apatite would actually cause further production of U(IV) for its own fixation, as it would disturb the achievement of equilibrium. This action would be even more pronounced than the stabilizing effect of complexing with phosphate or fluoride in solution as equilibrium may be reached in the latter case.

All of the above reactions favoring production of $\mathrm{U}^{+4}$ presuppose the interaction of uranium with another reducing couple. On the other hand the relative instabiilty of $\mathrm{U}^{+4}$, in the form of $\mathrm{UO}_{2}$, to air oxidation is revealed by the many secondary minerals associated with vein deposits of uranium and the fact that uraninite or pitchblende is virtually never pure $\mathrm{UO}_{2}$, but more commonly $\mathrm{U}_{3} \mathrm{O}_{8}$, or some intermediate value. We have shown experimentally (table 24 ) that apatite pellets encrusted with iron oxide have the capacity to oxidize $\mathrm{U}$ (IV) in solution to uranyl. From the above evidence, as well as the fact that $\left(\mathrm{UO}_{2}\right)^{+2}$ is the dominant ion under most natural conditions (Garrels, 1955), it is reasonable to expect that weathering causes a lowering of the initial $\mathrm{U}(\mathrm{IV}) / \mathrm{U}(\mathrm{VI})$ ratio in marine phosphorites. The very features of excessive porosity and surface area that permit contemplation of adsorbed $\left(\mathrm{UO}_{2}\right)^{+2}$ in phosphorites also permit thorough permeation by air and oxygen-bearing water. Such extensive contact with oxygen could effect appreciable alteration of $\mathrm{U}^{+4}$ to $\left(\mathrm{UO}_{2}\right)^{+2}$, despite the fact that other, more obvious, weathering changes might not occur. External oxidation would be augmented by the disruptive effects of radioactive disintegration on the crystal structure and by the liberation of oxygen from water as a result of apha particle bombardment (Ellsworth, 1925).

Conclusive evidence that weathering has lowered the initial $\mathrm{U}(\mathrm{IV}) / \mathrm{U}(\mathrm{VI})$ ratio is obtained in the Tennessee phosphorites. There, the residually accumulated "brown-rock" ores maintain essentially the same $\mathrm{P}_{2} \mathrm{O}_{5} / \mathrm{U}$ ratio as the underlying parent limestone (table 18 ), thus proving that uranium has not been added or subtracted. In contrast the U(IV) content has been lowered from 25 percent to 3 percent of the total uranium (table 23).

The fact that the highest $U(I V) / U$ percentages (and therefore the highest $U(I V) / U(V I)$ ratios) are obtained from youngest and least weathered rocks becomes doubly significant in view of the above evidence. The high U(IV) contents of pebbles from the basal Bone Valley formation of Pliocene age and of nodules dredged off the coast of California (p. 72 and table 23) suggest that the uranium fixed by apatite from marine waters is largely tetravalent and that long exposure has allowed oxidation to lower the $\mathrm{U}(\mathrm{IV}) / \mathrm{U}$ perventages in the Phosphoria and Bigby formations.

Few samples of the Phosphoria and Bigby formations have been studied and the hypothesis of initially higher $\mathrm{U}(\mathrm{IV}) / \mathrm{U}(\mathrm{VI})$ ratios must be tested with more data and specific comparisons of weathered and obviously unweathered materials. It can be urged in support of the idea, however, that McKelvey and Carswell (1956) infer a history of weathering from changes in $\mathrm{P}_{2} \mathrm{O}_{5}$ and uranium contents in various exposures of the Phosphoria formation, and they note unquestionable instances of weathering in other exposures. In addition, it is difficult to assume that the $\mathrm{U}(\mathrm{IV}) / \mathrm{U}$ percent of 25 , for limestone of the Bigby formation in the Tennessee phosphate field, represents the initial U(IV) content, and not a lowered value, superimposed by oxidative weathering. In view of the striking field evidences of weathering in the origin of the Tennessee "brown-rock" ores (pl. 12) and the substantial decrease of their $\mathrm{U}(\mathrm{IV}) / \mathrm{U}$ percentage from 25 to 3 , it is highly probably that the immediately underlying parent limestone, the Bigby formation, was also altered and that its primary $\mathrm{U}(\mathrm{IV}) / \mathrm{U}$ percentage was appreciably higher than 25 .

It is not possible to suggest how much of the primary uranium taken up by marine apatite was U(IV). It is clear however that significant amounts of $U(V I)$ are present initially, even though U(IV) may be the dominant species, and that the primary $U(I V) / U(V I)$ ratio in apatite is undoubtedly influenced by the Eh of the marine waters. 


\section{URANIUM IN IGNEOUS APATITE}

GENERAL STATEMENT AND ANALYSES

In accordance with Goldschmidt's empirical rules, U(IV) should be preferentially emplaced or "captured" in apatite due to its size identity with the Ca+2 ion and the greater binding capacity of its higher charge. Considering the existence of such preferred emplacement in sedimentary apatite (see p. 59), and also the progressive increase in uranium content in the younger products of differentiation (Larsen and Phair, 1954; Adams, 1954), apatite might be expected to contain more uranium in the more felsic members of an intrusive series. Unfortunately, too few groups of related intrusive bodies have been investigated extensively enough to test such generalizations. To demonstrate the type of progressive concentration that might be a consequence of capture, it is necessary to compare the uranium contents and the relative amounts of apatite and other uranium-bearing minerals in each rock type, and also the uranium content and the relative volumes of the different rock types. It is, in effect, the problem of illuminating the total budget of uranium before one can understand individual expenditures of it.

The determinations of $\mathrm{U}$ and $\mathrm{U}(\mathrm{IV})$ in apatite require as much as 100 milligrams of pure mineral. To obtain this quantity of a small accessory mineral large samples of representative rock specimens must be carefully processed through several time-consuming operations. The paucity of uranium analyses for apatite in the literature reflects the prohibitive nature of the task. The analyses ${ }^{7}$ given in table 27 are hardly representative of all igneous apatite. They, nevertheless, give some idea of the range and typical values for uranium content. The apatites, all cases, were optically clear, subhedral to euhedral, and contained few inclusions. An exception is the apatite from Mineville, N. Y., which is not properly igneous in origin, is exceedingly high in rare earths, and has many inclusions (McKeown and Klemic, 1956). Excluding the unusual Mineville material, all the apatites fall within the range of 0.001 to 0.012 percent of uranium. Most of them fall within the narrower limits of 0.004 to 0.008 percent of uranium.

The rocks sampled come mainly from a few batholiths and the selection is heavily weighted in favor of intermediate "acid" igneous types. As exemplified by the Boulder Creek batholith, they reveal the fact that the range in uranium content of apatites from a group of related rocks is not large in contrast to the dispersion that may obtain in sedimentary deposits. Significantly,

Te are greatly indebted to H. W. Jaffe, David Gottfried, E. S. Larsen, Jr., and George Phair, for supplying many of the apatite samples.
TABLE 27.-Uranium and U(IV) content of igneous apatites

IU(IV) was determined after solution of sample in $\mathrm{HCl}-\mathrm{NH}_{2} \mathrm{OH} \cdot \mathrm{HCl}$ solution. Values shown are corrected to compensate for the 80 percent recovery by this method (Clarke and Altschuler (1958). Analyst, R. S. Clarke, Jr.]

\begin{tabular}{|c|c|c|c|c|c|}
\hline Sample & Material & Area & $\begin{array}{c}\text { Total U U } \\
\text { (per- } \\
\text { cent) }\end{array}$ & $\begin{array}{l}\text { U(IV) } \\
\text { (per- } \\
\text { cent) }\end{array}$ & $\frac{\mathrm{U}(\mathrm{IV})}{\mathrm{U}}$ \\
\hline \multicolumn{6}{|c|}{ Boulder Creek batholith } \\
\hline GP $-17 \ldots$ & Granodilorite....... & Gold Hill, Colo......... & 0.0069 & 0.0019 & 28 \\
\hline GP-10 & Quartz monzonite. & Magnolia, Colo......... & .0053 & .0012 & 23 \\
\hline GP-34 & Quartz monzonite. & West of Boulder, Colo. & .0078 & .0019 & 24 \\
\hline GP-129.. & Quartz diorite..... & Tungsten, Colo........ & .0049 & .0012 & 24 \\
\hline GP-49_... & & $\begin{array}{l}\text { South Beaver Creek, } \\
\text { Colo. }\end{array}$ & .0011 & .00030 & 27 \\
\hline $\mathrm{GP}-50 \ldots$ & Quartz monzonite & $\begin{array}{l}\text { West of Tremont } \\
\text { Mountain, Colo. }\end{array}$ & .0048 & .0011 & 23 \\
\hline GP-51. & Quartz monzonite. & $\begin{array}{l}\text { West of Tremont } \\
\text { Mountain, Colo. }\end{array}$ & .0044 & .0012 & 27 \\
\hline GP-63...- & Granite. & $\begin{array}{l}\text { West of El Dorado } \\
\text { Snrings }\end{array}$ & .0023 & .00024 & 10 \\
\hline GP-61.... & Quartz diorite..... & Tungsten, Colo... & .0005 & n. d. & \\
\hline
\end{tabular}

"Silver Plume" dikes intrusive into Boulder Creek batholith

\begin{tabular}{|c|c|c|c|c|c|}
\hline \multirow{2}{*}{$\begin{array}{l}\text { GP-28..... } \\
\text { GP-41.... } \\
\text { GP-100... }\end{array}$} & \multirow{2}{*}{ Granite dike_..... } & \multirow{3}{*}{$\begin{array}{l}\text { Gordon Gulch, Colo.- } \\
\text { Wallstreet, Colo...... } \\
\text { Flagstaff Mountain, } \\
\text { Colo. }\end{array}$} & \multirow{3}{*}{$\begin{array}{l}0.00044 \\
.0022 \\
.0017\end{array}$} & \multirow{3}{*}{$\begin{array}{r}0.00014 \\
.00027 \\
.00039\end{array}$} & \multirow{3}{*}{$\begin{array}{l}32 \\
12 \\
23\end{array}$} \\
\hline & & & & & \\
\hline & -- & & & & \\
\hline \multicolumn{6}{|c|}{ Idaho batholith } \\
\hline CPR-117-- & Diorite. & \multirow{4}{*}{$\begin{array}{l}\text { Hailey, Idaho....... } \\
\text { Horseshoe Bend, } \\
\text { Idaho. } \\
\text { Quartzburg district, } \\
\text { Idaho. } \\
\text { Hamilton, Mont...... }\end{array}$} & \multirow{2}{*}{$\begin{array}{r}0.0059 \\
.0032\end{array}$} & \multirow{2}{*}{$\begin{array}{r}0.0025 \\
.0017\end{array}$} & \\
\hline CPR-118_- & -....do_. & & & & 53 \\
\hline CPR-119.. & $\ldots$....do. & & .0015 & .00086 & 5 \\
\hline CPR-122. & Gneissic granite... & & .0013 & .00086 & 6 \\
\hline \multicolumn{6}{|c|}{ Miscellaneous } \\
\hline Dur-1. & A patite-magne- & Durango, Mexico.. & 0.0010 & 0.0006 & \\
\hline $\mathrm{P}-4$ & Quartz diorite. & Southern California & .012 & .0057 & 4 \\
\hline & & $\begin{array}{l}\text { batholith, Lake- } \\
\text { view Mountain, } \\
\text { Calif. }\end{array}$ & & & \\
\hline $\mathrm{P}-22$ & Gabbro... & Henderson, N. C... & .00066 & .00036 & \\
\hline & Syenite_. & $\begin{array}{l}\text { Renfrew, Ontario, } \\
\text { Canada. }\end{array}$ & .0023 & .00052 & \\
\hline 53-BE-3a & onzonite_ & Shelby, N. C....... & .0061 & .0032 & \\
\hline $53-B E-3 b$ & Quartz monzonite. & Shelby, N. C........ & .0065 & .0041 & \\
\hline$K_{0}-1 \ldots$ & Apatite massif .... & Kola Peninsula, USSR & .001 & n. d. & \\
\hline FK-3..... & $\begin{array}{l}\text { Apatite-magnetite } \\
\text { deposit. }\end{array}$ & Mineville, N. Y....... & .079 & n. d. & \\
\hline G-25. & Shonkinite... & Mountain Pass, Calif & .0049 & n. d. & \\
\hline
\end{tabular}

these analyses also show that the changes are not necessarily progressive, as apatites from the more felsic rocks are not more uraniferous than those from intermediate rocks. The explanation may lie in the progressive increase in the quantity of the other uraniferous accessory minerals. Studies of E. S. Larsen, Jr. and George Phair, and their colleagues confirm this suggestion (oral communication, 1957). 


\section{VARIATION OF URANIUM IN APATITE WITH} URANIUM IN HOST ROCK

It is noteworthy that the uranium content of the apatites from the Boulder Creek batholith varies almost directly as the uranium content of the host rocks. ${ }^{8}$ This is shown in figure 15. The rocks are slightly to moderately different in composition and are from localities as much as several miles apart. The fact that most of the analyses conform so closely to a uniform trend of concentration of uranium in apatite relative to host rock indicates that the partition of uranium between apatite and the crystallizing magma can maintain a constant ratio over a significant interval of the differentiation span of the magma. That such equilibrium does not necessarily prevail throughout differentiation is indicated by the aberrant point on the plot, GP-63.

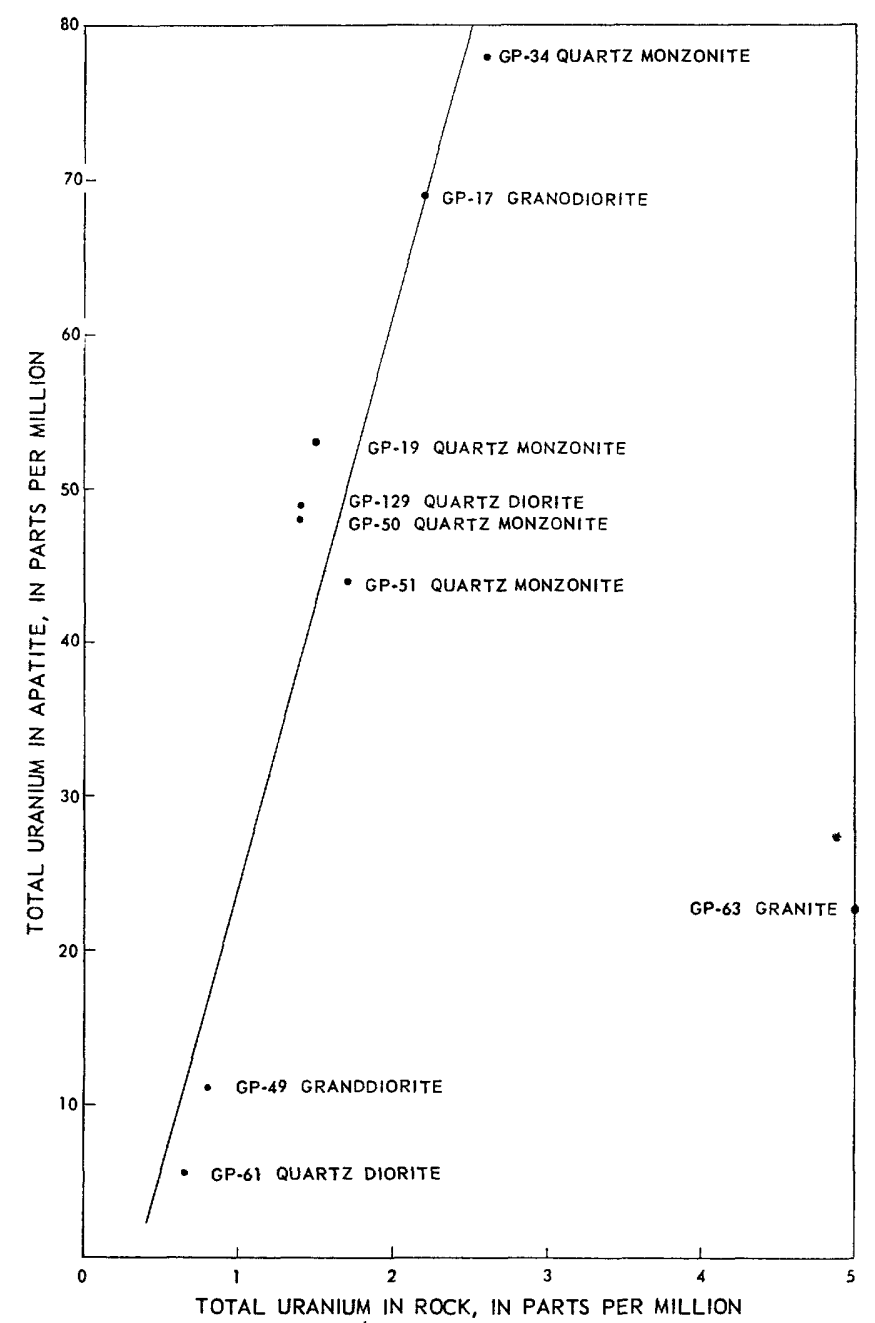

FIGURE 15.-Total uranium in rock vs. total uranium in apatite for rocks from Boulder Creek batholith.

\footnotetext{
8 We are indebted to George Phair for uranium determinations
} of total rock for this comparison.

\section{OXIDATION STATE OF URANIUM IN IGNEOUS APATITE}

In the absence of analytical data the uranium in igneous apatite has been reasonably presumed to be entirely tetravalent (Tomkeieff, 1946; Goldschmidt, 1954; Larsen and Phair, 1954; McKelvey and others, 1955). The conclusion is virtually dictated by the following:

1. The common occurrence of uraninite in the same or related rocks;

2. The implications of uranium occurring largely in other calcium and cerium-bearing minerals such as sphene, monazite, xenotime, and allanite, a fact presumably governed by the ability of $\mathrm{U}^{+4}$ to substitute for the $\mathrm{Ce}^{+3}$ and $\mathrm{Ca}^{+2}$ ions;

3. The occurrence of cerium and thorium in igneous apatite;

4. Independent evidence of the effectiveness of reducing conditions during the crystallization of the host rocks (Larsen and Phair, 1954; Adams, 1954).

It is reassuring to demonstrate that $U(I V)$ actually occurs in igneous apatite in view of the geologic arguments favoring this occurrence. Fewer data, gathered earlier (Altschuler and others, 1954), showed that more than half the uranium in some igneous apatite was reduced. Appreciable U(IV) has been found in all samples analyzed; however, with more comprehensive sampling it is now seen that many apatites may have more $U(V I)$ than $U(I V)$. It is not yet possible to define the controls of the relative $U(I V)$ and $U(V I)$ concentrations in igneous apatite. Many more analyses are required, not only for determination of the valence state of uranium in apatite, but also for other constituents of the parent rock and particularly for isotopes of lead (see discussion p. 82). It is possible, however, to discuss several alternative hypothesis on the basis of the data presented in table 27.

Of paramount importance is the fact (noted earlier, under sedimentary apatite) that consanguinous rocks yield similiar results when their apatites are analyzed for $U(I V)$. The virtual identity in the $U(I V) / U$ percentages of all but one of the Boulder Creek samples could not necessarily be anticipated unless apatites generally showed predominantly one or the other valence state. Rocks from the Idaho batholith show slightly more spread; the lithologies represented also differ more. In attempting to explain the obtained distributions of U(IV) it is important to note that U(IV) percentages have been found to range from 10 to 66 , and it is possible that more analyses may substantially widen the range.

It is conceivable that igneous apatite initially fixes more U(IV) during its crystallization than it now contains and that the increase in $U(V I)$ is superimposed by normal oxidative weathering. However, the 
lack of greater diversity in groups of related specimens argues strongly against so simple a hypothesis. Thus the total uranium content of the Boulder Creek apatites range from 0.0011 to 0.0078 percent. In view of this range and of the demonstrated possible range in U(IV) (10 to 66 percent of the total), the regularity that prevails in the $U(I V) / U$ percentages of the Boulder Creek apatites would be remarkable if it were caused by so variable a process as weathering, in which local, external factors (such as permeability and groundwater composition) play so large a role. It is pertinent to observe that the original rock samples and the apatite separates were carefully screened for evidence of alteration, and only fresh materials were used.

\section{U(IV)/U(VI) RATIO REFLECTS MAGMATIC EQUILIBRIA}

Two other hypothesis may be considered to account for the consistent $\mathrm{U}(\mathrm{IV}) / \mathrm{U}$ (VI) ratios ${ }^{9}$ in groups of apatites with much more diverse total uranium contents :

1. The $U(I V) / U(V I)$ ratios may be entirely a function of the conditions prevailing during the crystallation of the magma and be inherited unchanged.

2. The $\mathrm{U}(\mathrm{IV}) / \mathrm{U}$ (VI) ratios may be related to radioactivity and to age. This second explanation does not preclude the application of the first, as the percent of U(IV) may have been initially determined by the prevalent equilibria of the magma during erystallization and it may have since been altered regularly by radioactivity.

Much evidence can be marshalled for the first of the above viewpoints. Figure 15 demonstrates that the uranium in the apatite is in equilibrium with the total uranium in the rock and therefore, assuming the confined crystallization of phanerocrystalline rocks, with the magma from which these rocks crystallized. It follows that the uniform $U(I V) / U(V I)$ ratio in these apatites varies directly with the total uranium in the crystallizing magma. The progressive change in uranium content with differentiation in a series of related igneous rocks has been documented in the radioactivity studies of Billings and Keevil (1946) and the chemical studies of Larsen and others (1956). In addition, Adams has shown that total uranium has a linear relation to total $\mathrm{K}_{2} \mathrm{O}$ in the volcanic rocks of the Lassen Peak region. In these rocks "potassium increases systematically during differentiation" (Adams, 1954).

Obviously uranium responds to the major chemical equilibria that control differentiation. The above evidence that trace percentages of $U(I V)$ in apatite are

\footnotetext{
9 Previous sections were concerned with the amounts of the total uranium that is tetravalent; bence the percentage $U(I V) / U$ was used. Here, relative quantities of $U(I V)$ and $U$ (VI) are discussed and their ratio is used. Obviously the ratio and the percentage are based on the same figures and demonstrate the same trends.
}

directly related to uranium in the total rock (fig. 15) reveals that the $\mathrm{U}(\mathrm{IV}) / \mathrm{U}(\mathrm{VI})$ ratio in apatite might vary regularly with differentiation. Goldschmidt (1954) pointed out the progressive development of "magmatic oxidation" displayed by the increasing ratio of ferric to ferrous iron in mafic to felsic rocks, and he also noted that the iron oxide and sulfide mineral assemblages are compatible with the ferric-ferrous ratio. It is reasonable to suppose that uranium in plutonic apatite would similarly reflect the overall oxidation capacity of the magma and that the $U(I V) / U(V I)$ ratio would change accordingly in a large series of related rocks. Precise proof of this, however, must await a much larger assemblage of data.

\section{RELATION OF U(IV)/U(VI) RATIO TO AGE AUTO-OXIDATION}

The hypothesis that the $U(I V) / U(V I)$ ratio in igneous apatite is a function of radioactivity and varies regularly with age is more difficult to apply. Essentially, it proposes that the $\mathrm{U}(\mathrm{IV}) / \mathrm{U}$ (VI) ratio is governed by auto-oxidation. The concept of autooxidation was first proposed by Ellsworth $(1924,1925)$ who stated that the disintegration of $\mathrm{UO}_{2}$ or $\mathrm{ThO}_{2}$ to $\mathrm{Pb}$ must automatically oxidize $\mathrm{UO}_{2}$, or other reduced species present, in the following manner

$$
\begin{aligned}
\mathrm{UO}_{2} & \rightarrow \mathrm{Pb}+20 \\
20+\mathrm{UO}_{2}+\mathrm{Pb} & \rightarrow \mathrm{UO}_{3}+\mathrm{PbO}
\end{aligned}
$$

Subsequent decay of the $\mathrm{UO}_{3}$ thus produced will, in turn, oxidize two more $\mathrm{UO}_{2}$ (Holmes, 1948) as follows:

$$
\begin{aligned}
\mathrm{UO}_{3} & \rightarrow \mathrm{Pb}+30 \\
30+2 \mathrm{UO}_{2}+\mathrm{Pb} & \rightarrow 2 \mathrm{UO}_{3}+\mathrm{PbO}
\end{aligned}
$$

Thus, in net, one mole of $\mathrm{UO}_{3}$ is produced for each mole of radiogenic lead and, ideally, one might use $\mathrm{U}(\mathrm{VI}) / \mathrm{U}$ ratios to compute the ages of rocks and minerals in substantially the same manner that leaduranium ratios are now used, as was proposed by Lane (1934).

Three assumptions underlie the use of auto-oxidation as an age method. First, all or most of the uranium present in a mineral was originally tetravalent; second, none of the U(VI) now present was produced by weathering; third, uranium has not been differentially leached or added to rock.

Tomkeieff (1946) found that $\mathrm{UO}_{3}$ in uraninite cannot be explained solely by auto-oxidation. In studying the lead and $\mathrm{UO}_{3}$ contents of 52 collected analyses, he demonstrated that natural uraninite varies greatly and always contains more $\mathrm{UO}_{3}$ than is demanded by the auto-oxidation hypothesis. 
These findings are not surprising in view of the ease with which $\mathrm{UO}_{2}$ may be weathered. Indeed, Brooker and Nuffield (1952) have found that surface oxidation affects the peripheral zones of individual pitchblende specimens enough to change their cell edge constants relative to the material from the interior of the same specimens.

Despite the fact that pure $\mathrm{UO}_{2}$ is not known in nature, it is possible that uraninite may crystallize substantially free of $\mathrm{UO}_{3}$. If such material is unweathered and relatively free of water and $\mathrm{Fe}^{+2}, \mathrm{Ce}^{+3}$, or other reduced species, it can be used to test the theory that $\mathrm{UO}_{3}$ is formd by auto-oxidation and that the $\mathrm{UO}_{3} / \mathrm{U}$ ratio is an index of geologic age. Tomkeieff (1956), by averaging analyses, found that auto-oxidation might account for a significant part of the $\mathrm{UO}_{3}$ in uraninite. The demonstration by Holmes (1948) that the Khito Island uraninites yield $\mathrm{UO}_{3}$ ages that are in very good agreement with the lead-uranium ages derived from the same specimens shows that autooxidation may be the principal mechanism in producing $\mathrm{UO}_{3}$ in many minerals.

The uniformity of the $\mathrm{UO}_{3} / \mathrm{U}$ percentages of the apatites from the Boulder Creek batholith and, to a lesser extent, the Idaho batholith, plus the fact that the apatite from the much younger Idaho batholith rocks have much lower $\mathrm{UO}_{3} / \mathrm{U}$ percentages, suggest that the $\mathrm{UO}_{3}$ was produced by an internal process that is a function of time, rather than superimposed by an external process such as oxidative weathering.

It is difficult, however, to visualize the direct operation of auto-oxidation in producing $\mathrm{UO}_{3}$ in igneous apatite in view of the widespread dispersion of uranium in apatite ( 0.01 percent of uranium equals 1 atom of uranium per 2400 unit cells of apatite) and the fact that $\mathrm{Fe}$ and $\mathrm{Ce}$ in igneous apatite equal or exceed uranium.

We can evaluate auto-oxidation in apatite quite simply by premising all initial uranium in apatite as $U(I V)$. On this basis the age of the apatite can be determined by using the charts or the formula published by Wickman (1939). As discussed above, we may substitute the $\mathrm{U}$ (VI)/U ratio for the $\mathrm{Pb} b^{206} / \mathrm{Pb}^{238}$ ratio.

The U(VI)/U ratios of the Boulder Creek apatites (excluding sample GP-63) yield ages between 4.0 and 4.5 billion years. Ages obtained by the ratio of lead to alpha activity (Larsen and others, 1952) in zircon from the same rock are close to 1 billion years (David Gottfried, U. S. Geological Survey, oral communication, 1956). This latter age demands a U(VI) content of approximately 15 percent of the total $U$ rather than 75 percent of it.
Ages based on U(VI)/U ratios of the Idaho batholith apatites range from 2.4 to 3.6 billion years. Ages from the lead-alpha activity ratios of zircon from the same rock range from 60 to 110 million years $(H$. Jaffe, U. S. Geological Survey, oral communication, 1957). These would demand U(VI) contents of only 0.8 to 1.5 percent of the total $U$ rather than 34 to 58 percent of it.

\section{EXTERNAL WEATHERING CONTROLLED BY RADIO- ACTIVE DECAY}

Despite the fact that the contribution of thorium has not been taken into account in the above evaluations, the results show so great an excess of $\mathrm{UO}_{3}$ as to invalidate the hypothesis that auto-oxidation produced the $\mathrm{UO}_{3}$, or even contributed significantly to it. It is possible, however, that radioactive disintegration can indirectly facilitate and control the ratio of external oxidation by solutions and gases present in the rocks and, hence, produce an effect like auto-oxidation. Such control on crystal permeation by oxidizing agents could be established by progressive increase in crystal damage because of radioactive decay. Ellsworth (1925) pointed out the following disruptive effects of radiation on crystal structure:

1. Intracrystalline fracturing due to volume changes caused by auto-oxidation of Ce, Fe, and U(IV),

2. Fracturing due to volume changes caused by radioactive heat,

3. Structural dislocation caused by recoil forces in atoms emitting alpha particles,

4. Dislocation caused by alpha particle bombardment.

The effectiveness of radiation damage in increasing the cell dimensions of quartz and zircon has been demonstrated by Hurley and Fairbairn (1953). In addition, oxygen liberated by the decomposition of structural or absorbed water as a result of alpha radiation would effect further oxidation.

In summary, the relative $U(I V)$ and $U(V I)$ contents of igneous apatites are most readily attributed to oxidation conditions during the crystallization of the host rocks. The consistency evident among some groups of related rocks, however, indicates that initial $\mathrm{UO}_{3}$ contents may be progressively augmented by autooxidation or external oxidation, at a systematic rate, and it is of interest to investigate the relations of radioactive decay to such contributions to $\mathrm{UO}_{3}$ content. To do so requires much more uranium data and a comparison of $U(V I) / U$ ratios with radiogenic lead.

\section{CONCLUSIONS \\ SUMMARY}

Uranium in apatite ranges from a few parts per million $(0.000 \mathrm{X}$ percent) in the insular phosphorites to almost 1 percent in subaerially enriched deposits. 
The most typical deposits, those comprising the greatest concentrations of $\mathrm{P}_{2} \mathrm{O}_{5}$ in the lithosphere, are far more restricted in range. Primary apatite, both igneous and sedimentary, generally, has between 0.005 and 0.015 percent of uranium. Thus, igneous apatite seldom exceeds 0.01 percent and primary apatite pellets from the Hawthorn and Phosphoria formations typically contain 0.005-0.008 percent of uranium; the rich Moroccan phosphorites contain about 0.012 to 0.014 percent (with remarkable consistency).

The uranium in apatite may be leached or enriched, and its enrichment may take place subaerially from ground water or during submarine reworking. Marine enrichment commonly enhances uranium content in apatite to 0.02 to 0.03 percent, as shown in the Bone Valley formation and the South Carolina terrace gravels. The fact that unweathered marine phosphorite seldom exceeds 0.03 percent of uranium, however, can be attributed only to the infinitesimally small concentrations in the marine source, rather than to any limitations of the apatite structure or to the competition of other ions for replacement sites. This is evident from the much greater content of uranium in subaerially enriched apatite, in which much additional uranium is emplaced long after the normal suite of other trace elements substituting for calcium. Thus pebbles in the Bone Valley formation are supergenely enriched to 0.2 percent of uranium, and fossil bones contain as much as 0.83 percent of uranium. Significantly, the $\mathrm{U}(\mathrm{IV})$ content in each of the above is more than half of the total uranium.

The characteristics of geologically young marine phosphorites enlighten us both as to the capacity and the nature of marine sources of uranium. Phosphatic marls from the Gulf of Mexico and phosphorite nodules from the Pacific Ocean have a $\mathrm{U} / \mathrm{P}_{2} \mathrm{O}_{5}$ ratio as high or higher than those of any of the world's major phosphate deposits that have been investigated, thus proving that ocean water is an adequate source of uranium in typical marine phosphorite.

\section{NATURE OF URANTUM FIXATION IN PHOSPHORITES}

The suggestion that uranium in phosphorites is dominantly U(VI) fixed as a surface-coordinated uranyl pyrophosphate has been advanced (Bowie and Atkin, 1956) to account for the lack of uranium in calcareous sediments. However, the well-established ability of carbonate to complex uranyl ion and thus increase the solubility of uranium (Bachelet and others, 1952) more probably accounts for the relative lack of uranium in carbonate rocks. Furthermore, the surface-limited reactions of uranyl ion with bone apatite demonstrated by
Neuman and others (1949a, b) are structurally much more limited that the isomorphous replacement of $\mathrm{Ca}^{+2}$ by $\mathrm{U}^{+4}$, and it is not surprising that an apatite material with as much as 0.83 percent total uranium should contain more than half the uranium as U(IV). Some of the U(VI) in unweathered phosphorites is probably chemisorbed by surface reaction of uranyl on the growing crystallites of sedimentary apatite. Such reactions are, in nature, more likely to involve orthophosphate than pyrophosphate formation. In addition, the high U(IV) content of young phosphorites suggests that postdepositional oxidation has also produced appreciable $U(V I)$ in the older rocks.

Were mere adventitious extraction the sole factor in uranium fixation by precipitating apatite, the ratio of uranium to phosphate in apatite might approximate their relative concentrations in the sea. Uranium in sea water is 1-2 parts per billion. $\mathrm{P}_{2} \mathrm{O}_{5}$ in sea water of the Continental Shelf is $50 \mathrm{mg} / \mathrm{m}^{3}$ (Kazakov 1937). The $\mathrm{U} / \mathrm{P}_{2} \mathrm{O}_{5}$ ratio in sea water is thus 0.02-0.04 and thereby exceeds by far the ratio of $\mathrm{U} / \mathrm{P}_{2} \mathrm{O}_{5}$ found in primary marine phosphorites (table 12). In addition, comparison of $\mathrm{U} / \mathrm{P}_{2} \mathrm{O}_{5}$ ratios both within and among the primary pellets and nodules from the Hawthorn formation, Florida, the Gulf of Mexico, the Pacific Ocean, and French Morocco (table 12), reveals considerable variety for comparable materials. Thus, direct and indiscriminate fixation of uranium that is available fails to explain the known uranium contents in apatite. Nor can these known contents be explained merely by citing an "affinity" of uranium for phosphate that is demonstrated by the many uranium phosphate minerals, as these are entirely uranyl minerals, and we have found that in relatively young, primary phosphorite most of the uranium is present in the tetravalent or, uranous, form.

It seems, indicated from the above, that the uranium actually available to apatite must be limited and largely contingent on special circumstances, presumably, the production of U(IV). Garrels (1955) and Sheldon (written communication, 1957) have shown from thermodynamic considerations of the isolated couple $\left(\mathrm{UO}_{2}\right)^{+2}$ and $\mathrm{U}^{+4}$ that the uranyl concentration of normal sea water would be many orders of magnitude greater than that of the uranous ion. It is only in an acid reducing environment that the U(IV) concentration becomes significant (Garrels, 1955). Even under these conditions $(\mathrm{pH}=6, \quad \mathrm{Eh}=-0.3)$, the $\left(\mathrm{UO}_{2}\right)^{+2} / \mathrm{U}^{+4}$ ratio is about 100 (Sheldon, written communication, 1950); however, apatite cannot be considered to form from such water of relatively high. acidity. 
It follows from the insolubility of $U(I V)$ in ground water solutions that uranium is delivered to the ocean as $\left(\mathrm{UO}_{2}\right)^{+2}$. However, uranyl ion may be readily reduced at low temperature and pressure to $U(I V)$ and as the concentrations of ferrous iron and organic matter in marine phosphorites is generally far greater than the concentration of uranium, the necessary marine reduction of $U(V I)$ prior to apatite fixation may be readily presumed.

The substantial ground-water and marine enhancements of uranium in apatite reveal the potency of apatite to remove uranium selectively from terrestrial or marine solutions. U(IV) produced by reduction reaction between $\left(\mathrm{UO}_{2}\right)^{+2}$ and $\mathrm{Fe}^{+2}$, or organic matter, would be taken up as a proxy for calcium during formation of apatite, or by ion exchange of calcium during marine reworking of previously formed apatite.

Unweathered pebbles from the Bone Valley formation and nodules of Quaternary age from the Pacific Ocean contain dominantly tetravalent uranium. This indicates that the hexavalent uranium in sea water is, in fact, reduced prior to emplacement in apatite. Further proof of this is obtained from the demonstration that new increments of marine uranium in the transgressively reworked Pleistocene terrace gravels near Charleston, South Carolina are mainly U(IV). In contrast to these findings, the marine phosphorites containing prominent $\mathrm{U}(\mathrm{VI})$ have been obviously weathered or are geologically much older (and probably weathered). It is therefore believed that the U(VI) present in marine phosphorites is derived largely from postdepositional oxidation of U(IV).

\section{REGENERATIVE CAPTURE}

In contrast to igneous apatite the occurrence of uranium in marine sedimentary apatite is not governed solely by the equilibrium conditions prevailing during the precipitation of the apatite. This follows from the evidence of secondary enrichment during marine reworking; namely, the host mineral acquiring new increments of the trace element by re-exposure to the same or similar solutions. It is also indicated by the wide variation in the $\mathrm{U} / \mathrm{P}_{2} \mathrm{O}_{5}$ ratios in unaltered primary, or first-cycle, phosphorites, a fact which would otherwise demand considerable variation in the uranium content of the marine sources, for which there is no evidence. It is proposed that apatite actively affects the course of the reduction reactions which might normally produce $U(I V)$ in the following manner:

$\left(\mathrm{UO}_{2}\right)^{+2}+$ Reductant $\rightleftharpoons \mathrm{U}^{+4}+$ Oxidized reductant

The presence of apatite as a precipitating or solid phase which can sequester the $\mathrm{U}^{+4}$ by solid solution or ion exchange for calcium, interferes with the attainment of equilibrium in the above reaction and drives it instead in the direction:

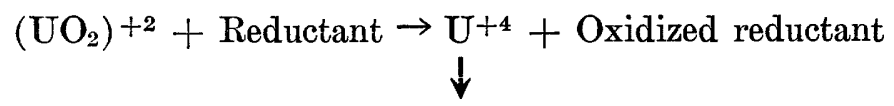

Thus by removal of U(IV) in an insoluble phase, apatite promotes an additional reduction of uranyl and thereby insures a continuing supply of U(IV) for its own uptake. The removal of U(IV) from sea water is thus not dependent on continuous precipitation of apatite, as uptake may proceed equally by ion-exchange reaction with previously formed apatite. This is indicated by the higher total $U$ and $U(I V)$ contents of reworked phosphate nodules.

The name, regenerative capture, is proposed to describe this type of trace element concentration in which a stable complex or insoluble phase, by effectively removing an ion species that is normally present in insignificant quantities, prevents the attainment of equilibrium in the oxidation-reduction reaction producing this ion, and causes continuous production of the ion. Thus, as long as removal continues, the supply is maintained and a mineral is able to fix unusual concentrations of an ion species which, from mere stability or concentration considerations, would not be expected in large quantities. Regenerative capture can be maintained only as long as the host mineral remains unsaturated with respect to the trace constituent. The fact that apatite can concentrate as much as 0.5 percent of U(IV) proves that saturation conditions are seldom realized in typical marine apatite (0.01-0.02 percent of $\mathrm{U}$ ).

The idea of regenerative capture clearly invokes no new chemical principle. Its merit lies in explaining unexpectedly large mineral concentrations of ions present in insignificant concentrations in solution. Regenerative capture applies to uranium in apatite in two important ways. It helps to explain the high U(IV)/ $\mathrm{U}$ (VI) ratios of some marine phosphorites despite the fact that uranium in the ocean source most probably occurs predominantly as $\mathrm{U}(\mathrm{VI})$. It implies that a strongly reducing environment is not a requirement for the fixation of $U(I V)$ by apatite but rather that appreciable $U(I V)$ may be fixed by apatite so long as any reduction of $U(V I)$ is possible.

\section{EQUIIIBRIUM FIXATION OF URANIUM IN IGNEOUS APATITE}

A completely different situation prevails in igneous apatite. The presence of many other good hosts makes the entire distribution of uranium much more complex and the amount of uranium available to apatite is regu- 
lated not only by its inherent capacity but by the capacities of other hosts coextensive with it and thus reflects the total equilibrium in the magma. This is clearly evident from the systematic variation of both the total uranium and the $U(I V) / U(V I)$ ratio in apatite with the total uranium in the rock, for suites of related rocks.

\section{SELECTED REFERENCES}

Adams, J. A. S., 1954, Uranium and thorium contents of volcanic rocks, in Faul, Henry, ed., Nuclear geology, p. 89-98: New York, John Wiley and Sons.

Alexander, Frank, 1953, Guidebook, flield trip to central Tennessee phosphate district-Southeastern Mineral Symposium, Geol. Soc. America : Nashville, Vanderbilt Univ., Tennessee Div. Geology, 8 p.

Altschuler, Z. S., Cisney, F. A., and Barlow, I. H., 1953, X-ray evidence of the nature of carbonate-apatite (abs.) : 19th Internat. Geol. Cong., Algiers, Comptes rendus, sec. 11, fasc. 11, p. 9.

Altschuler, Z. S., Clarke, R. S., and Young, E. J., 1954, Uranium in apatite (abs.): Geol. Soc. America Bull., v. 65, no. 12, pt. 2, p. 1225-1266.

Altschuler, Z. S., Jaffe, E. B., and Cuttitta, Frank, 1956, The aluminum phosphate zone of the Bone Valley formation, Florida, and its uranium deposits: Proc. Internat. Conf. on Peaceful Uses of Atomic Energy, Geneva, 1955, v. 6, p. 507-513; U. S. Geol. Survey Prof. Paper 300, p. 495-504.

Arambourg, Camille, and Orcel, Jean, 1951, Observations préliminaires sur a présence d'un vanadate d'urane dans les gisements de phosphate du Maroc: Acad. Sci. Paris Comptes rendus, v. 233 , no. 25 , p. $1635-1636$.

Bachelet, M., Cheylan, E., Douis, M., and Goulette, J. C., 1952, Préparation et propriétés des uranylcarbonates; $2^{\circ}$ note: Uranylcarbonates alcino-terreux: Soc. chim. France Bull., p. 565-569.

Baes, C. F., Jr., 1954, The production of $\mathrm{U}^{4+}$ by ferrous ion in phosphoric acid solution; the formal electrode potential of the $\mathrm{U}^{4+}-\mathrm{U}^{6+}$ couple: U. S. Atomic Energy Comm. ORNL1581 or AECD-3594. (Microcard copy on file in U. S. Atomic Energy Comm. depository libraries.)

Barr, J. R., Jr., 1955, Uranium production from phosphate rock : Remarks at 39th Ann. Mtg. Florida Eng. Soc., Daytona Beach, Florida, U. S. Atomic Energy Comm.

Beevers, C. A., and McIntyre, D. B., 1946, The atomic structure of fluorapatite and its relation to tooth and bone material: Mineralog. Mag., v. 27, no. 194, p. 254-257.

Billings, M. P., and Keevil, N. B., 1946, Petrography and radioactivity of four Paleozoic magma series in New Hampshire : Geol. Soc. America Bull., v. 57, p. 797-828.

Borneman-Starinkevitch, I. D., 1938, On some isomorphic substitutions in apatite: Acad. Sci. U.R.S.S., Comptes rendus (Doklady), จ. 19, no. 4, p. 253-255.

Bowie, S. H. U., and Atkin, D., 1956, An unusually radioactive fossil fish from Thurso, Scotland: Nature, v. 177, no. 4506 , p. $487-488$.

Brooker, E. J., and Nuffield, E. W., 1952, Studies of radioactive compounds, IV-Pitchlende from Lake Athabaska, Canada : Am. Mineralogist, v. 37, p. 363-385.
Capdecomme, Laurent, 1953 Etude mineralogique des gites dephosphates alumineux de la region de Thiès (Sénégal) : Internat. Geol. Cong., 19th, Algiers, Comptes rendus, sec. 11, fasc. 11, p. 103-117.

Capdecomme, Laurent, and Pulou, Rene, 1954, Sur la radioactivité des phosphate de la region de Thiès (Sénégal): Acad. Sci. Paris Comptes Rendus, v. 239, p. 288-290.

Carnot, Adolphe, 1893, Recherches sur la composition générale et la teneur en fluor des os modernes et des os fossiles des différents âges: Annales des mines, ser. 9, v. 3, p. 155-195.

Cathcart, J. B., 1950, Notes on the land-pebble phosphate deposits of Florida, in Snyder, F. G., ed., Symposium on mineral resources of the southeastern United States, 1949 proceedings : Knoxville, Tenn. Univ. Press, p. 131-151.

1956, Distribution and occurrence of uranium in the calcium phosphate zone of the land-pebble phosphate district of Florida : Proc. Internat. Conf. on the Peaceful Uses of Atomic Energy, Geneva, 1955, v. 6, p. 514-519; U. S. Geol. Survey Prof. Paper 30, p. 489-494.

Cathcart, J. B., Blade, I. V., Davidson, D. F., and Ketner, K. B., 1953, The geology of the Florida land-pebble phosphate deposits : 19th Internat. Geol. Cong., Algiers, Comptes rendus, sec. 11, fasc. 11, p. 77-91.

Clarke, R. S., Jr., and Altschuler, Z. S., 1958, Determination of the oxidation state of uranium in apatite and phosphorite deposits: Geochimica et Cosmochimica Acta, v. 13, nos. 2/3, p. 127-142

Connick, R. E., and Hugus, Z. Z., The participation of $f$ orbitals in bonding in uranium and transuranium elements: Am. Chem. Soc. Jour., จ. 74, p. 6012-6015.

Davidson, C. F., and Atkin, D., 1953. On the occurrence of uranium in phosphate rock: 19th Internat. Geol. Cong., Algiers, Comptes rendus, sec. 11, fasc. 11, p. 13-31.

Denson, N. M., and Gill, J. R., 1956, Uranium-bearing lignite and its relation to volcanic tuffs in eastern Montana and North and South Dakota: Proc. Internat. Conf. on the Peaceful Uses of Atomic Energy, Geneva, 1955, v. 6, p. 464467 ; U. S. Geol. Survey Prof. Paper 300, p. 413-418.

Dietz, R. S., Emery, K. O., and Shepard, F. P., 1942, Phosphorite deposits on the sea floor off southern California: Geol. Soc. America Bull., v. 53, p. 815-848.

Du Toit, A. L., 1917, The phosphates of Suldanha Bay: South African Geol. Survey Mem. 10, 34 p.

Ellis, D. A., 1952, The recovery of uranium from industrial phosphoric acids by solvent extraction: U. S. Atomic Energy Comm., DOW-81, 79 p.

Ellsworth, H. V., 1924, Atomic disintegration as a measure of geologic time: Pan. Am. Geologist, v. 42, p. 273-280.

1925, Radioactive minerals as geologic age indicators: Am. Jour. Sci., 5th ser., v. 9, p. 127-144.,

Fairchild, J. G., 1929, Base exchange in artificial autunites: Am. Mineralogist, v. 14, p. 265-275.

Garrels, R. M., 1955, Some thermodynamic relations among the uranium oxides and their relation to the oxidation states of the uranium ores of the Colorado Plateaus: Am. Mineralogist, v. 40, nos. 11 and 12, p. 1004-1021.

Goldschmidt, V. M. (by Alex Muir, ed.), 1954, Geochemistry : Oxford, Clarendon Press, 730 p.

Graton, L. C., and Fraser, H. J., 1935, Systematic packing of spheres with particular relation to porosity and permeability : Am. Assoc. Petroeum Geologists Bull., v. 43, no. 8, p. 785-909. 
Green, Jack, 1953, Geochemical table of the elements for 1953 : Geol. Soc. America Bull., v. 64, p. 1001-1012.

Grimaldi, F. S., May, Irving, and Fletcher, M. H., 1952, U. S. Geological Survey fluorimetric methods of uranium analysis: U. S. Geol. Survey Circ. 199, 20 p.

Grimaldi, F. S., May, Irving, Fletcher, M. H., and Titcomb, Jane (Compilers), 1954, Collected papers on methods of analysis for uranium and thorium: U. S. Geol. Survey Bull. 1006, $184 \mathrm{p}$.

Gruner, J. W., 1952, New data on syntheses of uranium minerals. -Part I. Annual Report for July 1, 1951 to June 30, 1952: U. S. Atomic Energy Comm. RMO-983, 26 p.

Gruner, J. W., and McConnell, Duncan, 1937, The problem of the carbonate-apatites. The structure of francolite: Zeitschr. Kristallographie, จ. 97, p. 208-215.

Guntz, A. A., 1952, Sur la présence d'uranium dans les phosphates Nord-Africains: Acad. Sci. Paris Comptes Rendus, v. 234, p. 868-870.

Hayes, C. W., and Ulrich, E. O., 1903, Description of the Columbia quadrangle, Tennessee U. S. Geol. Survey. Geol. Atlas, Columbia folio, 95.

Hébert, Claude, 1947, Contribution à l'étude de la chimie des phosphates de calcium: Annales des mines, Mem., v. 136, no. 4, 93 p.

Hendricks, S. B., and Hill, W. L., 1950, The nature of bone and phosphate rock: Natl. Acad. Sci. Proc., v. 36, p. 731-737.

Holmes, Arthur, 1948, The oldest known minerals and rocks : Edinburgh Geol. Soc. Trans., v. 14, pt. 2, p. 176-194.

Hurley, P. M., and Fairbairn, H. W., 1953, Radiation damage in zircon-a possible age method: Geol. Soc. America Bull., v. 64, p. 659-673.

Igelsrud, Iver, Chocholak, John, Stephan, E. F., and others, 1949, Recovery of uranium from phosphate rock by the Battelle monocalcium phosphate process: U. S. Atomic Energy Comm. BMI-JDS-201, 99 p.

Igelsrud, Iver, Stephan, E. F., Choeholak, John, and others, 1948: Chemical process to recover uranium from phosphate rock : U. S. Atomic Energy Comm., BMI-JDS-126, 29 p.

Jacob, K. D., Hill, W. L., Marshall, H. L., and Reynolds, D. S., 1933, The composition and distribution of phosphate rock with special reference to the United States: U. S. Dept. Agriculture Tech. Bull. 364, 90 p.

Jacob, K. D., and Hill, W. L., 1953, Laboratory evaluation of phosphate fertilizers in Pierre, W. H., and Norman, A. G., ed., Soil and fertilizer phosphorus in crop nutrition, v. 4, chap. 11, p. 299-345, of Agronomy, [a series of monographs prepared under the auspices of the American Society of Agronomy] : New York, Academic Press.

Jaffe, E. B., and Sherwood, A. M., 1951, Physical and chemical comparison of modern and fossil tooth and bone material: U. S. Geol. Survey TEM-149, 19 p., issued by U. S. Atomic Energy Comm. Tech. Inf. Service Extension, Oak Ridge, Tenn.

Kazakov, A. V., 1937, The phosphorite facies and the genesis of phosphorites in Geological investigations of agricultural ores USSR: Sci. Inst. Fertilizers and Insectofungicides Trans. (USSR), no. 142, p. 95-113. (Special issue in English published for 17th Internat. Geol. Cong.)

Lane, A. C., 1934, Fivefold check of uraninite age?: Am. Mineralogist, v. 19, no. 1, p. 1-13.
Larsen, E. S., Jr., Keevil, N. B., and Harrison, H. C., 1952, Method for determining the age of igneous rocks using the accessory minerals : Geol. Soc. America Bull., v. 63, p. 10451052.

Larsen, E. S., Jr., and Phair, George, 1954, The distribution of uranium and thorium in igneous rocks, in Faul, Henry, ed., Nuclear geology, p. 75-89: New York, John Wiley and Sons.

Larsen, E. S., Jr., Phair, George, Gottfried, David, and Smith, W. L., 195̌6, Uranium in magmatic differentiation: Proc. Internat. Conf. on Peaceful Uses of Atomic Energy, Geneva, 1955 , v. 6, p. 240-247; U. S. Geol. Survey Prof. Paper 300, p. 65-74.

LeCornec, J., 1951, Estimate of world supplies of the principal plant nutrients by cost range: U. N. Sci. Conf. Conserv. and Utiliz. Res. Proc., v. 2, Mineral resources, p. 270-274.

Lenoble, André, Salcan, Henri, and Ziegler, Valery, 1952, Decouverte de l'uranium dans les niveaux phosphates du Maroc: Acad. Sci. Paris Comptes rendus, v. 234; no. 9, p. 976-977.

McConnell, Duncan, 1938, A structural investigation of isomorphism of the apatite group: Am. Mineralogist ,v. 23, no. 1, p. 1-19.

McKelvey, V. E., and Carswell, L. D., 1956, Uranium in Phosphoria formation: Proc. Internat. Conf. in the Peaceful Uses of Atomic Energy, Geneva, 1955, v. 6, p. 503-506 ; U. S. Geol. Survey Prof. Paper 300 , p. 483-487.

McKelvey, V. E., Cathcart, J. B., Altschuler, Z. S., and others, 1953, Domestic phosphate deposits, in Pierre, W. H., and Norman, A. G., eds., Soil and fertilizer phosphorus in crop nutrition, v. 4, chap. 11, p. 347-376, of Agronomy, a series of monographs, prepared under the auspices American Society of Agronomy: New York, Academic Press.

McKelvey, V. E., Everhart, D. L., and Garrels, R. M., 1955, Origin of uranium deposits: Econ. Geology, 50th Anniversary volume, 1905-1955, pt. 1, p. 464-533.

McKeIvey, V. E., and Nelson, J. M., 1950, Characteristics of marine uranium-bearing sedimentary rocks : Econ. Geology, จ. 45, p. 35-53.

McKeown, F. A., and Klemic, Harry, 1956, Rare-earth-bearing apatite at Mineville, Essex County, New York: U. S. Geol. Survey Bull. 1046-B, p. 9-23.

MacNeil, F. S., 1947, Correlation chart for the outcropping Tertiary formations of the eastern Gulf region: U. S. Geol. Survey Oil and Gas Inv. Prelim. Chart 29, with text.

Malde, H. E., Geology of the Charleston phosphate area, South Carolina: U. S. Geol. Survey Bull. _— (in press).

Miller, L. J., and Kerr, P. F., 1954, Progress report on the chemical environment of pitchblende in Annual Report for June 30, 1953 to April 1, 1954, pt. 2: U. S. Atomic Energy Comm. RME-3096, 98 p.; see p. 72-92.

Moore, G. W., 1954, Extraction of uranium from aqueous solution by coal and other materials: Econ. Geology, v. 49, p. $652-658$.

Neuman, M. W., and Neuman, W. F., 1948, The deposition of uranium in bone, II-Radioautograph studies: Jour. Biol. Chemistry, v. 175, no. 2, p. 711-714.

Neuman, W. F., Neuman, M. W., Main, E. R., and Mulryan, B. J., 1949a, The deposition of uranium in bone, V-Ion exchange studies: Jour. Biol. Chemistry, v. 179, p. 335-340. - 1949b, The deposition of uranium in bone, VI-Ion competition studies: Jour. Biol. Chemistry, v. 179, p. 341-348. 
Oakley, K. P., 1955a, Analytical methods of dating bones, in Techniques in Archaeology : Advancement of Science, v. 11, no. $45 ;$ p. $3-8$.

$1955 \mathrm{~b}$, The composition of the Piltdown hominoid remains: British Mus. Nat. History Bull., Geology, v. 2, no. 6, p. 254-265.

Palache, Charles, Berman, Harry, and Frondel, Clifford, 1951, Dana's system of mineralogy, v. 2, 7th ed. : New York, John Wiley and Sons, $1224 \mathrm{p}$.

Pannell, J. H., 1950, Aid oxidation of uranous solutions: U. S. Atomic Energy Comm. MITG-261, 18 p.

Piénkowski, S., 1953, Radioactivé d'un groupe de phosphorites polonais I : Acad. Polonaise Sci. Bull., Cl. III, v. 1, p. 39-41.

Piggot, C. S., and Urry, W. D., 1941, Radioactive relations in ocean water and bottom sediments: Am. Jour. Sci., v. 239, p. 81-91.

Rogers, G. S., 1913, The phosphate deposits of South Carolina: U. S. Geol. Survey Bull. 580-J, p. 183-220. [1915].

Runnels, R. T., Schleicher, J. A., and Van Nortwick, H. S., 1953, Composition of some uranium-bearing phosphate nodules from Kansas shales: Kansas Geol. Survey Bull. 102, pt. 3, p. 93-104.

Rusakov, V. P., 1933, O soderzhanii radiya i toriya $\mathbf{v}$ fosforitakh [The radium and thorium content of phosphorites] : Akad. Nauk SSSR, Leningrad, Doklady (Compte rendus) ser. A, no. 3, p. 25-33.

Russ, W., 1924, The phosphate deposits of Abeokuta Province: Nigeria Geol. Survey Bull. 7, p. 9-38.

Schreyer, J. M., 1954, The chemistry of uranium (IV) orthophosphate solutions. Part I. The solubility of uranium (IV) orthaphosphates in phosphoric acid solutions: U. S. Atomic Energy Comm. ORNL-1747, 34 p.
Silverman, S. R., Fuyat, R. K., and Weiser, Jeanne D., 1952, Quantitative determination of calcite associated with carbonate-bearing apatites: Am. Mineralogists, v. 37, p. 211-222.

Smith, K. G., and Bradley, D. A., 1952, Radioactive dinosaur bones from the Camp Davis region, western Wyoming: Michigan Acad. Sci. Papers 1951, v. 37, p. 257-263.

Strutt, R. J., 1906, On the distribution of radium in the earth's crust: Royal Soc. London Proc. Ser. A, v. 78, p. 150-153.

- 1908, On the accumulation of helium in geologic time: Royal Soc. London Proc. Ser. A, v. 81, p. 272-277.

Thompson, M. E., 1953, Distribution of uranium in rich phosphate beds of the Phosphoria formation: U. S. Geol. Survey Bull. 988-D, p. 45-67.

- 1954, Further studies of the distribution of uranium in rich phosphate beds of the Phosphoria formation: U. S. Geol. Survey Bull. 1009-D, p. 107-123.

Tomkeieff, S. I., 1946, The geochemistry of uranium: Sci. Progress, v. 34, no. 136, p. 696-712.

Volodchenkova, A. I., and Melentiev, B. N., 1943, Apatites of two textural types from apatite-nepheline rocks of Chibing: Acad. Sci. U.R.S.S., Comptes rendus (Doklady) v. 39, no. 1, p. 34-35.

Weiner, J. S., Oakley, K. P., and Le Gros Clark, W. E., 1953, The solution of the Piltdown problem: British Museum (Natural History) Bull., Geology, v. 2, no. 3, p. 141-146.

Wells, A. F., 1950, Structural inorganic chemistry, 2d ed., 727 p. ; Oxford, Clarendon Press.

Wickman, Frans E., 1939, Some graphs on the calculation of geological age: Stockholm, Sveriges geol. Undersökning, ser. C, no. 427, Arsbok 33, no. 7, 8 p. 



\section{INDEX}

Page

Abstract

Acknowledgments

Akin mine, Tennessee

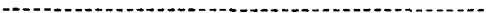

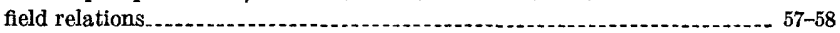
origin petrography -

Aluminum phosphates................................................ 57-61, 65

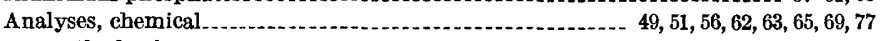

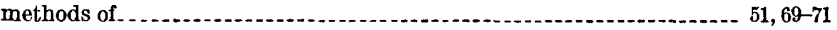

Angaur Island, Pacific Ocean.............. 51

Apatite, complete chemical analyses................................... 49

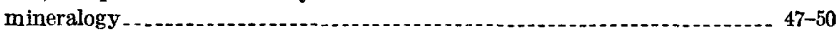
spectrographic analyses............................................ 49 structure of uranium content

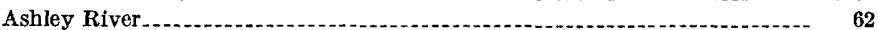

Ashley River flood plain

Autoradiograph $\ldots$

Auto-oxidation - . -

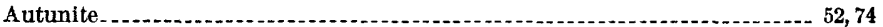

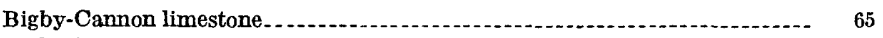

Bigby formation

Bone Valley uranium content in fossils from

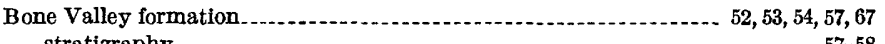

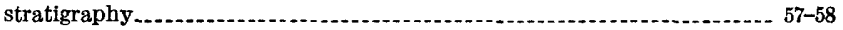
weathering...........- 57-60

Bones, uranium content

Bonny Lake mine, Florida

Bonny Lake pebbles

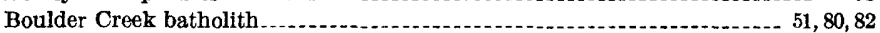

Boyette mine, Florida

Brown-rock phosphate

Calcite

Calcium, leaching and replacement of

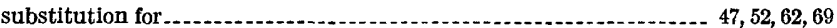

Calcium aluminum phosphates......................................... $57-60$

Carbonate-apatite

Cave phosphates, partial analyses ...................................... 51-52

Cerium, in apatite

oxidation or reduction of uranium by ................................ 69, 82

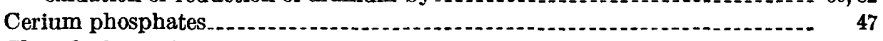

Cloverly formation, uranium content of bones................................ $\quad 66$

Conclusions. -

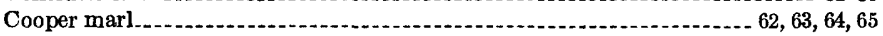

Coupled diodochy, in phosphate minerals.

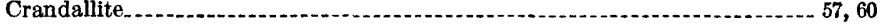

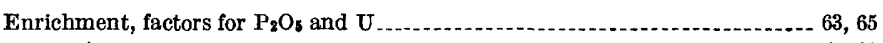
marine................. 67-68 postdepositional ........................ 59 residual

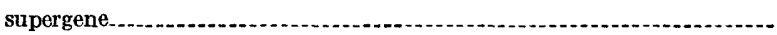
uranium

Equivalent uranium $\ldots \ldots \ldots \ldots$

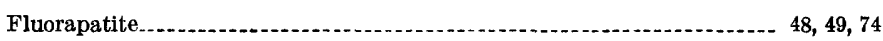

Fluorescence, in apatite nodules.................................... 53

Fluorine, excess in apatite......................................................... 45,77 in apatite structure................................ $47,75,77$

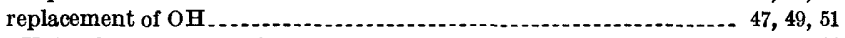

Fort Union formation, uranium content.................................. 66

Fremont County, w yo., apatite deposit_..................................... 68

Granule, term defined.

Guano-derived phosphorites

Gulf of California

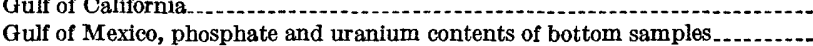

Page

Hells Creek formation, uranium content

Idaho batholith

age of apatites of ......... 82

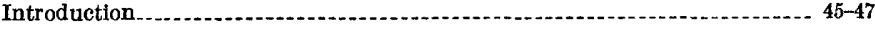

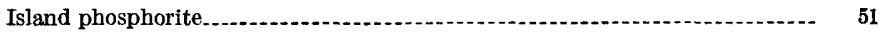

Khito Island, age of uraninites of Khouribga, French Moroceo

Land Pebble field, Florida......................................... 52, 54, 56, 57, 58

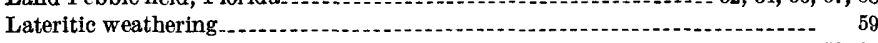

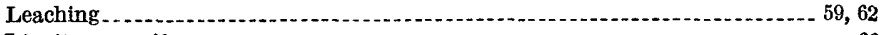

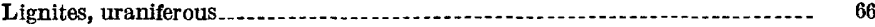

Magmatic oxidation

Marine phosphate deposits........................................................ 52

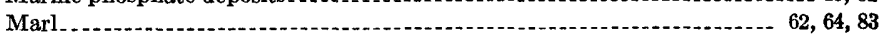

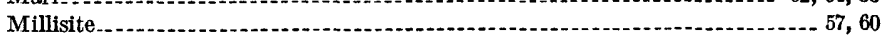

Mona Island, Puerto Rico, analyses of cave phosphorite...................... 51-52

Nodule, term defined .......................................................... 49

Nodules, phosphorite, from Pacific Ocean

Nuclear emulsion studies................................................ 68

Old Red sandstone

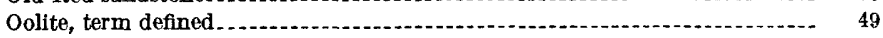

Organic content, correlation with uranium

relationship to reducing conditions.................................. $63,72,84$

Oulad-Abdoun, French Morocco, phosphate beds................ 53-54

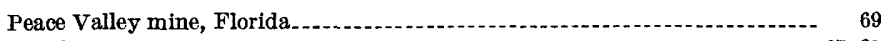

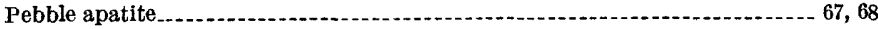

Phosphate deposits, Florida................................ 51, 53, 56, 57, 65, 68 French Morocco_.......................................... 53, 56, 67, 68

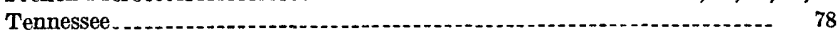

terrace gravel near Charleston, S. C............................... $\quad 77$

Phosphate fertilizer, production in United States............................... 46

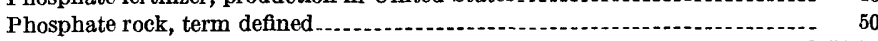

Phosphoria formation

Phosphorite, spectrographic analyses...................................... 64

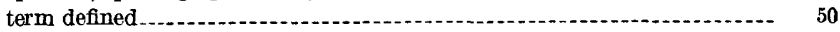
Phosphorite pebble, term defined

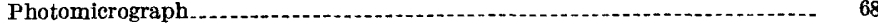

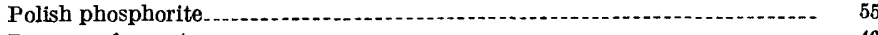
Purpose of report.

Radioactive decay

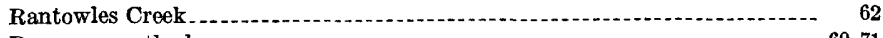

Recovery methods

References, selected

Replacement, subaerial

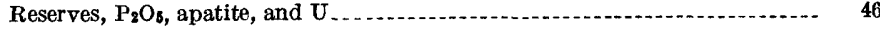

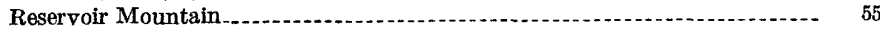

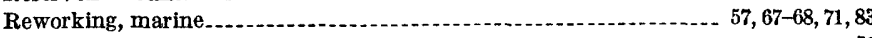

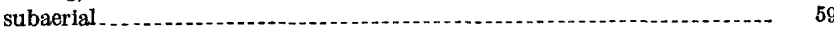

Sedimentary apatite Sedimentary carbonate-apatites, composition.................................. 48-49

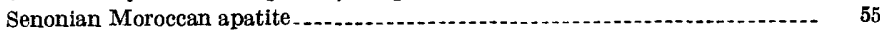

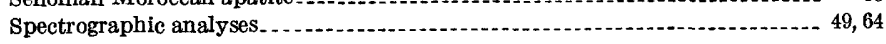

Terminology, petrographic

Thorium, content in Florida pebble phosphorite

in igneous rocks and minerals._.

$\begin{aligned} \text { source of radioactivity in fossils. } & 66 \\ \text { Titanium } & \end{aligned}$ 
Page

Uraninite, oxides and anto-oxidation in ... 81-82

ranium, as byproduct of phosphate productio

correlation with other elements

crystallo-chemical nature in apatite.

distribution in phosphate pebbles.

experimental oxidation and reduction of . .

form and manner of occurrence in phosphorites........................ 52-56

in igneous apatite............. 79-82

in sea water . .

marine sources of . . . . .

marine versus ground-water origin in phosphorite

oxidation or reduction by other elements........................... $69-71,73,82,8$

oxidation state in apatite . . . . .

reserves in phosphorite.......... 46

secondary emplacement in bones

substitution for calcium in apatite................... 69-75

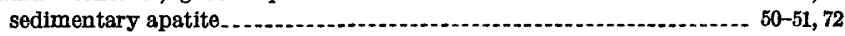

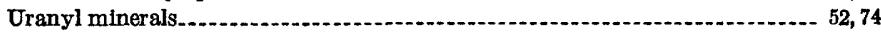

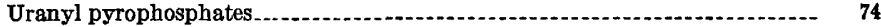

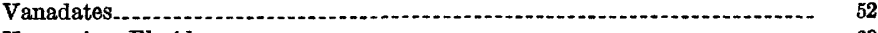

Varn mine, Florida

Watson mine, Florida 69

Wavellite

Weathering

lateritic

redistribution of elements during................................... $60-61,63-64$

uranium oxidation during ............................................. 72-73, 82,84

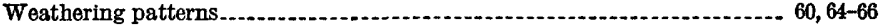

X-ray powder diffraction analysis 